\title{
DEVELOPMENT OF NEW SMART METAL NANOMATERIALS BASED ON TITANIUM-DIOXIDE FOR PHOTOCATALYTIC AND ANTIMICROBIAL ACTIVITIES
}

\author{
Nataša D. Kuburovića ${ }^{a}$ Aleksandar V. Golubovićb \\ Ljiljana M. Babinčev ${ }^{\mathrm{C}}$ \\ ${ }^{a}$ Eco Energy Engineering \& Consulting, Belgrade, Republic of Serbia, \\ e-mail: natasa.kuburovic@eeec.rs, \\ ORCID iD: Dhttp://orcid.org/0000-0003-2565-6607 \\ ${ }^{\mathrm{b}}$ University of Belgrade, Institute of Physics, Center for Solid State \\ Physics and New Materials, Belgrade, Republic of Serbia, \\ e-mail: golubovic@ipb.ac.rs, \\ ORCID iD: Dhttp://orcid.org/0000-0003-4618-424X \\ ${ }^{c}$ University of Priština, Faculty of Technical Sciences, \\ Kosovska Mitrovica, Republic of Serbia \\ e-mail: Ijiljana.babincev@pr.ac.rs \\ ORCID iD: Dhttp://orcid.org/0000-0001-6290-1902
}

DOI: 10.5937/vojtehg66-17261; https://doi.org/10.5937/vojtehg66-17261

FIELD: Chemical \& Materials Engineering, Catalytic processes and Composite Materials

ARTICLE TYPE: Original Scientific Paper

ARTICLE LANGUAGE: English

ACKNOWLEDGMENT: The first author would like to express her gratitude to Dr Suzana Dimitrijević - Branković, full professor at the Faculty of Technology and Metallurgy, University of Belgrade, for her kind help in the preparation of microorganisms and their measurements during the experimental research, as well as for her useful suggestions. Also, the first author is especially grateful to colleague Dr Antonije Onjia, Ph. D. Sci Ch. Eng., Associate Professor at the Faculty of Technology and Metallurgy, University of Belgrade, owner and long lasting director of the Anahem Laboratory d.o.o., for his generous help and the opportunities to support necessary analyses during the first author's scientific research work done in his lab. The photocatalytic and coupled photocatalytic-microbiological experiments were carried out in the Laboratory of the Department for Organic Chemistry at the Faculty of Technology and Metallurgy, University of Belgrade, which the first author used for scientific research work during her $\mathrm{PhD}$ study in Inorganic Chemical Technology and Chemical Engineering. The microbiological activity experiments were carried out in the Laboratory of Biochemical Engineering and Biotechnology at the FTM BU. The synthesis and part of characterization of $\mathrm{TiO}_{2}$ nanoparticles were carried out in the Center for Solid State Physics and New Materials at the Institute of Physics, University of Belgrade. The GC-MS determinations were carried out in the Laboratory of the "Occupational Safety and Environmental Protection, Beograd doo". 


\section{Abstract:}

The subject of this study was the synthesis, characterization and testing of titanium (IV) oxide nanoparticles $\left(\mathrm{TiO}_{2}-\mathrm{NPS}\right)$ and their lanthanum $\left(\mathrm{La}^{3+}\right)$, iron $\left(\mathrm{Fe}^{3+}\right)$ and vanadium $\left(\mathrm{V}^{3+}\right)$ dopants for the photocatalytic and microbiological activity, as well as their comparison with the catalytic activity of the tested commercial $\mathrm{TiO}_{2}$ (Degussa $P-25^{\circledR}$ and anatase nanoparticles, $99.9 \%$, Alfa Aesar Lancaster). The $\mathrm{TiO}_{2}-\mathrm{NPs}$ photocatalysts were synthetized and doped with different metal dopants concentrations for different calcination durations, such as: $\mathrm{TiO}_{2}-\mathrm{NPs}$ (anatase-NPs, calcination duration of 5 and $7 \mathrm{~h}$ ), $\mathrm{La}^{3+}(0.65,1,2,3,4,5$ and 6 wt. \%, calcination duration of $7 \mathrm{~h}), \mathrm{Fe}^{3+}(1,2.5,3.0$ and 5 wt. \%, calcination duration of 7 and $24 \mathrm{~h})$, and $\mathrm{V}^{3+}$ (10 wt. \%, calcination duration of 7 and $24 \mathrm{~h}$ ). The Pseudomonas aeruginosa strains DV 2739 and ATCC 9023 were used as model microorganisms in the microbiological experiments performed in a microbiological cabinet. The photocatalytic and coupled photocatalytic-microbiological processes were performed in a slurry-catalyst bath circulation photoreactor in the presence of direct UV radiation simulated with a sodium lamp SONT UV400 in lab conditions. The study has demonstrated that the catalyst sample S28, an La-dopant with a concentration of $1 w t$. \%, displays the best photocatalytic properties among all La-dopants, while the best photocatalytic activity among all catalysts was achieved in S111 sample, an Fe-dopant of titania (5 wt. \%, calcination duration of $7 \mathrm{~h}$ ). Our results also show different degradation rates for $\mathrm{TiO}_{2}$ doped with $\mathrm{V}^{3+}$ of 10.0 wt. \%, samples $\mathrm{S93}$ and S96, synthetized with different duration times (7h and 24h, respectively) and calcination heating rates (66.7 and $135^{\circ} \mathrm{C} / \mathrm{h}$, respectively), which can be explained by anomalies in their behavior. Finally, the best antimicrobial activity is obtained in S24 sample, an Fe-dopant for which it was shown that $0.25 \mathrm{mg} / \mathrm{L}$ could be toxic for microorganisms. In accordance with our results of superior Fe-dopant characteristics and theoretical knowledge for $\mathrm{TiO}_{2}$ nanoparticles doped with $\mathrm{Ag}, \mathrm{Au}$ and $\mathrm{Fe}$, we get directions for further studies of their photocatalytic and antimicrobial activities, as well as for the development of $\mathrm{TiO}_{2}$-nanoparticles and nanotubes for enhancing antibiotics and their use in cancer treatment.

Key words: titanium-dioxide, $\mathrm{TiO}_{2}$-nanoparticles, $\mathrm{TiO}_{2}$ doped with $\mathrm{La}^{3+}$, $\mathrm{Fe}^{3+}$ and $\mathrm{V}^{3+}$, calcination duration, Pseudomonas aeruginosa strains DV 2739 and ATCC 9023, photocatalytic activity, antimicrobial activity.

\section{Introduction}

Titanium, the ninth most abundant element in the Earth's crust, can be found in the form of minerals: ilmenite, rutile and titanium. In its most stable form as titanium (IV) oxide $\left(\mathrm{TiO}_{2}\right)$, it can be found in three possible crystalline forms: brookite (orthorhombic), rutile (tetragonal) and anatase 
(tetrarombic). From a photocatalytic point of view, only rutile and anatase are relevant, the latter having the highest photocatalytic activity, as reported by Fernandez-lbanez et al (Fernández-lbáñez et al, 2004). Among different options available in the market, Degussa $\mathrm{P}-25^{\circledR}$ is one of the most efficient and tested nanomaterials, in the form of powder with a particle size of around $25 \mathrm{~nm}$, forming aggregates of several hundred nanometers to several micrometers in the aqueous solution with a surface of $50 \mathrm{~m}^{2} / \mathrm{g}$, consisting of $70 \%$ anatase and $30 \%$ rutile. It is well known that $\mathrm{TiO}_{2}$ with the anatase molecular structure was found to be a superior photocatalytic material for purification and disinfection of water and the air, as well as for the remediation of hazardous waste (Hoffmann et al, 1995), (Fujishima et al, 2000). Nanomaterials like $\mathrm{TiO}_{2}$ nanoparticles $\left(\mathrm{TiO}_{2}-\mathrm{NPs}\right)$, smaller than approximately $100 \mathrm{~nm}$ in diameter, have become a new generation of advanced materials due to their novel and interesting optical, dielectric, and photocatalytic properties from size quantization (Alivisatos, 1996). The challenge for the so-called nanotechnologies is to achieve perfect control of nanoscalerelated properties, which obviously requires correlating the parameters of the synthesis process, such as: self-assembly, microlithography, sol-gel, polymer curing, electrochemical deposition, laser ablation, etc. with the resulting nanostructure (Gouadec et al, 2007). Many efforts have been devoted to research, development and production of advanced $\mathrm{TiO}_{2}-\mathrm{NPs}$ with controlled size, shape, and porosity for use in thin films, nanowares and electrodes, catalysts, ceramics and composite materials. The effects of nanometer sizes are caused by the large surface-to-volume ratio, resulting in more atoms along the grained boundaries than in the bulk material, which can be explained by the fact that if many particles reduce their size, more attractive interactions between the particles become dominant so attractive forces lead them to aggregate or agglomerate, which results in nanoparticle aggregates (NPAs). The control of the particle size distribution and the aggregate structure is the key criterion for product quality considering that the desired product properties can vary with the particle size, as well as the degree of aggregation or aggregate structure. It has been accepted that NPs can exist in two states within a liquid: stable, i.e. particles separate, non-adhering and dispersed, and aggregated or flocculated, i.e. adherent and randomly clumped (Schwarzer \& Peukert, 2005). This clumping can occur due to van der Waals attractive forces or may be caused by magnetic or other attractions imposed by externally imposed fields. For the calculation of the particle-particle interaction, the DLVO theory can be employed (Hunter, 2000). Hence, it is very important to realize that the NPs being 
used in experiments, especially in a suspension or colloid form, have the properties (e.g., size distribution) which are different from those specified by manufactures; in experimental processes such as sonication, autoclave, $\mathrm{pH}$ value, etc., the state or properties of the particles may be changed, so it is essential that the experiments are carried out with care (Sungkaworn et al, 2008). With the increasing use of NPs in commerce, to date few studies have investigated the toxicological and environmental effects of NPs. Exposure to nanoparticle substances can be an important risk factor for human health. The sub-micron size of NPs offers a number of distinct advantages over micro particles (MPs). NPs have in general relatively higher intracellular uptake rate compared to MPs, which was demonstrated in studies in which $100 \mathrm{~nm}$ size NPs showed 2.5 fold greater uptakes compared to $1 \mathrm{~mm}$ and 6 fold higher uptakes compared to $10 \mathrm{~mm}$ NPs in Caco-2 cell line, as reported by Waliszewski (Waliszewski, 1997). Similar results were obtained when these formulations of NPs and MPs were tested in a rat in situ intestinal loop model. The efficiency of uptake of $100 \mathrm{~nm}$ sized particles was 15-250 fold greater than larger sized (1 and $10 \mathrm{~mm}$ ) MPs (Zhang \& Sun, 2004). In this rat study, it was found that NPs were able to penetrate throughout the sub mucosal layers while the larger size MPs were predominantly localized in the epithelial lining. Also, $\mathrm{TiO}_{2}$ or titanium could be used as an alternative complement to conventional technology for biocides activity via photocatalysis. It is well known that photocatalytic events occur when the UVA/UVB with wavelengths of lower than $385 \mathrm{~nm}(365<$ wavelength < 385) illumination of $\mathrm{TiO}_{2}$ (band-gap energy of anatase, 3.2 $\mathrm{eV}$; for rutile, $3.0 \mathrm{eV}$ ) and subsequent formation of electron/hole pairs are numerous and very complex; the following electron/hole separation, the two charge carriers migrate to the surface through diffusion and drift, in competition with a multitude of trapping and recombination events in the lattice bulk. The carriers are poised, at the surface, to initiate redox chemistry with suitable pre-adsorbed acceptor and donor molecules in competition with recombination events to yield radioactive and nonradioactive emissions, and/or trapping of the charge carriers into shallow traps at lattice sites (e.g., anion vacancies, $\mathrm{Ti}^{4+}$, and others). Thus, on absorption of UV light, titanium particles yield superoxide radical anions and hydroxyl radicals that can initiate oxidations (Hoffmann et al, 1995).

It is also well known that thinner nanowires (NWs) may further enhance the sensitivity of the devices owing to an increased surface-tovolume ratio, as Chueh et al. reported (Chueh et al, 2007). This study has shown the investigation of the $\mathrm{RuO}_{2} / \mathrm{TiO}_{2}$ core/shell structure 
photoconductivity under the UV illumination of $256 \mathrm{~nm}(4.9 \mathrm{eV})$, which is strong enough to excite the electron-hole pair near the band edge, and their results suggest the potential application of NWs as interconnects and optoelectronic devices

Photocatalytic-biological inactivation is explained by the attack of oxygen-derived molecular species or reactive oxygen species (ROS), especially radicals photo generated at the surface of the $\mathrm{TiO}_{2}$ catalysts like $\mathrm{O}_{2}^{-}, \mathrm{HO}_{2}$ and $\mathrm{OH}$, although the mechanism of cell death or damage has not been understood yet (Maness et al, 1999). Also, oxygen-derived molecular species or reactive oxygen species (ROS) such as superoxide $\left(\mathrm{O}_{2}{ }^{-}\right)$and hydrogen peroxide $\left(\mathrm{H}_{2} \mathrm{O}_{2}\right)$ are produced in cells as a result of aerobic metabolism. Excess generation of these species can result in damage to macromolecules such as the DNA and lipids (Maness et al, 1999). Photocatalytic $\mathrm{TiO}_{2}$ nanoparticles, as showed by Xu et al. (Xu et al, 1998) in their experimental research, have features to kill malignant cells through a series of oxidized chain reactions and induce the malignant cells to be stressed by ROS. Then, the cells were stressed to death either through apoptosis or necrosis depending on the used dosage. Finaly, photocatalytic $\mathrm{TiO}_{2}$ nanoparticles can severely destruct the cellular membrane system and cause the cellular genetic macromolecules damage through the reactive oxygen species accumulation within the cells, and even induce cell death. The result of this research (Xu et al, 1998) also partly reveals the mechanism of cell death by photocatalytic $\mathrm{TiO}_{2}$ nanoparticles, which is very important for the direction of the research and development of photocatalytic $\mathrm{TiO}_{2}$ nanoparticles in biomedical application.

Anpo (Anpo, M. 2004) reported that the nanosized anatase $\mathrm{TiO}_{2}$, due to a large surface area and band-gap energy, showed better photo activity than their bulk phase. However, the nanosized anatase- $\mathrm{TiO}_{2}$ transforms to the rutile structure at temperatures about $600^{\circ} \mathrm{C}$ and this phase transformation of $\mathrm{TiO}_{2}$ greatly reduces surface areas of the particles (Zhang \& Sun, 2004), which may result in the decrease in photocatalytic ability of $\mathrm{TiO}_{2}$. It was found that the stability temperature of the anatase- $\mathrm{TiO}_{2}$ can be increased by doping $\mathrm{TiO}_{2}$ with lanthanide ions; so it is believed that the development of high-temperature stabilized photocatalysts is important for immobilizing the photocatalyst on the working objects by chemically bonding, the process of which commonly requiresrelatively high temperatures. Zhang \& Sun (Zhang \& Sun, 2004) studied the microstructure and the photocatalytic properties of lanthanide doped $\mathrm{TiO}_{2}$ prepared by a sol-gel method and they reported that $\mathrm{La}, \mathrm{Eu}$, $\mathrm{Gd}$ or $\mathrm{Yb}$ dopants significantly inhibited the nanosized $\mathrm{TiO}_{2}$ phase 
transformation of anatase-to-rutile. It was also found that transition metal oxides are extensively employed as catalysts, because they possess featured active centers to adsorb reaction molecules. Titania doped with iron ions shows superior activity due to its unique half-filled electronic configuration and shallow trapping compared to other metal dopants with closed shell electronic configuration, which can be more effective to influence the photo activity (Yan et al, 2015), (Liu \& Zhang, 2013), (Ramli et al, 2015), (Su et al, 2015), (Dinesh et al, 2015), (Flak et al, 2015), (Su et al, 2012), (Wang et al, 2012). Theoretical and experimental studies show that $\mathrm{Fe}$ doping can effectively reduce the trapping density and charge recombination, resulting in drastically improved adsorption, reported Huang et al (Huang et al, 2016).

Many studies by the authors: Heller (Heller, 1995), Ollis et al (Ollis et al, 1991), Sitkiewitz \& Heller (Sitkiewitz \& Heller, 1996), Takeuchi et al (Takeuchi et al, 2003) and Uchida et al (Uchida et al, 1993); using $\mathrm{TiO}_{2}$ photodecomposition of pollutants with the aim of developing methods to purify water and the air have been carried out. For the bactericidal activity, several results have been reported using $\mathrm{TiO}_{2}$ powder (Cai et al, 1991), (Ireland et al, 1993), (Matsunaga \& Okochi, 1995), (Watts et al, 1995) and (Wei et al, 1994), and $\mathrm{TiO}_{2}$-coated materials for this purpose (Kikuchi et al, 1997). However, few studies have investigated the impacts of $\mathrm{TiO}_{2}$ in cancer science or in the field of oncology, as reported by Minhua et al. (Minhua, X. et al. 1998). However, the actual factors that control the photo catalytic activity of specific $\mathrm{TiO}_{2}$ particles are still unknown, and the detailed studies of the effects of $\mathrm{TiO}_{2}$ on biological systems in dark condition have been very rare. Cancer has been a leading cause of human death in the world, but it is not too much known about the biological mechanisms leading to the establishment or the growth of malignant tumors. Many attempts have been made in recent decades to describe the basic biological mechanisms of tumor growth. Benign masses generally have smooth, circumscribed, and well-defined contours, whereas malignant tumors commonly have rough, speculated, and ill-defined contours (Sungkaworn et al, 2008). Also, Fe-doped $\mathrm{TiO}_{2}$ nanotubes (NTs) can be a potential photosensitizer for the near-visible light driven photodynamic therapy (PDT) against cervical cancer cells (HeLa). Fe-doped $\mathrm{TiO}_{2}$ nanoparticles exhibited none or lower dark cytotoxicity than un-doped $\mathrm{TiO}_{2}$ nanotubes, which confirms their superior biocompatibility. Under the near-visible light irradiation $(\sim 405 \mathrm{~nm}), \mathrm{Fe}-$ doped $\mathrm{TiO}_{2}$ nanoparticles showed higher photo-cytotoxic efficacy than un-doped $\mathrm{TiO}_{2}$ nanoparticles, which was found to be dependent on the nanoparticles concentration, but not on the incubation time of the cells 
after the near-visible light irradiation. The highest activity was observed in 0.70 and 1.40 wt. \% $\mathrm{Fe}^{-\mathrm{TiO}_{2}}$ nanoparticles (Flak et al, 2015).

The aim of this study is finding the optimum synergetic effects of the synthetized type of smart $\mathrm{TiO}_{2}$-nanoparticles and their different metal dopant concentration on photocatalytic, microbiological and antimicrobial activities in aerobic conditions, which will give us further directions of the development of $\mathrm{TiO}_{2}$ nanoparticles for environmental and biomedical applications.

\section{Background of the $\mathrm{TiO}_{2}$-Particle Synthesis}

Many studies have been conducted on the synthesis of $\mathrm{TiO}_{2-}$ nanoparticle catalysts that will have adequate nanometres-sized effects, as well as other relevant catalyst and electrochemical characteristics, which can give best performances for photocatalytic, photoelectrochemical and antimicrobial activities.

Nedeljkovic et al. (Nedeljković et al, 1997) performed a $\mathrm{TiO}_{2}$ nanoparticles ultrasonic spray pyrolysis using a colloidal solution of $10^{-2} \mathrm{M} \mathrm{TiO}_{2}$ at $800^{\circ} \mathrm{C}$. The experimentally determined value of the mean diameter of $\mathrm{TiO}_{2}$ was $286 \mathrm{~nm}$. It differed significantly from the expected theoretical values between $132 \mathrm{~nm}$ and $195 \mathrm{~nm}$. Jokanovic et al. (Jokanović et al, 2004) explained the design of nanostructured hollow sized particles during the ultrasonic spray pyrolysis method, which was in comparison between theoretically estimated and experimentally obtained ring thickness about 7-15\%. The mean sub particle size estimated by the theoretical model was $4.7 \mathrm{~nm}$. Depending on the type of packing, the mean diameter of the hollow sphere was different: for hexagonal packing - $87 \mathrm{~nm}$, for cubic packing - $95 \mathrm{~nm}$, which is in accordance with the theoretical model developed by Jokanović.

Backman et al. (Backman et al, 2004) produced nanosized $\mathrm{TiO}_{2}$ particles using flame reactors and aerosol pyrolysis. The measured median sizes of $\mathrm{TiO}_{2}$ prepared from titanium (IV) tetraisopropoxide $\mathrm{Ti}\left(\mathrm{OC}_{3} \mathrm{H}_{7}\right)_{4}$ were $13 \mathrm{~nm}$ at $600-1100^{\circ} \mathrm{C}$ reactor's temperature and $22 \mathrm{~nm}$ at $1100^{\circ} \mathrm{C}$, respectively. The fundamental problem was the presence of carbon in the product that is produced at $1100^{\circ} \mathrm{C}$ since the processes of coalescence agglomeration and sintering are dominant at higher reaction temperatures $\left(1100^{\circ} \mathrm{C}\right)$, as opposed to $600^{\circ} \mathrm{C}$. The desired crystalline anatase phase of $\mathrm{TiO}_{2}$ was formed at high temperature. The TEM and BET analyses of $\mathrm{TiO}_{2}$-nanoparticles confirmed that by changing the temperature values the surface area and phase content can be controlled. 
Aruna et al reported a nanosized rutile $\mathrm{TiO}_{2}$ particle synthesis via a hydrothermal method without mineralizers, which contaminate the samples and induce undesirable characteristics (Aruna et al, 2000). It is also used for preparing two sets of titania colloids (with and without stirring) the similar procedure by hydrothermal synthesis of titanium (IV) isopropoxide and nitric acid with $\mathrm{pH}$ value of 0.5 . Stirring that maintains homogeneity in the solution during the hydrothermal process was highly important when a homogeneous product was required. The rutile nanocrystals of titania prepared by the hydrothermal method with a particle size of about $20 \mathrm{~nm}$ have a large surface area and are relatively stable at high temperatures.

Ahonen et al (Ahonen et al, 1999) synthetized $\mathrm{TiO}_{2}$-powders in the aerosol pyrolysis process of the freshly-prepared and well-mixed $0.2 \mathrm{M}$ solution of titanium (IV) n-butoxide in n-butanol at a temperature range between 200 and $580^{\circ} \mathrm{C}$ in the air and the nitrogen atmosphere. Anatase powder was formed at $500^{\circ} \mathrm{C}$ in nitrogen, and at $580^{\circ} \mathrm{C}$ in the air, while the anatase to rutile transformation appeared in thermal annealing in the air. Physico-chemical phenomena occurring during the formation of particles were described in this paper (Ahonen et al, 1999).

The methodology for the preparation of $\mathrm{TiO}_{2}$ films, based on the process of ultrasonic spray pyrolysis using $\mathrm{TiO}_{2}$ nanoparticles as a precursor was reported by Blesic et al (Blešić et al, 2002). Blesic et al have shown an advantage of the usage of $\mathrm{TiO}_{2}$ colloids in the process of ultrasonic spray pyrolysis. In the methodology, the growth mechanism of the $\mathrm{TiO}_{2}$ films formation is explained layer-by-layer. The compact smooth film or a porous structure might be obtained by adjusting the substrate temperature, and the mean diameter of particles can be adjusted changing the concentration of the precursor and a frequency of aerosol.

Panic et al (Panić et al, 2003) sythetized titanium anodes with an active $\mathrm{RuO}_{2}$ coating of two different thicknesses from the oxide suspended in ethanol, as an "ink" method, while the oxide itself was synthesized by the hydrolysis of ruthenium ethoxide in an ethanolic solution (alkoxide route). The authors showed that the anodes prepared via the alkoxide route are more active in the chlorine evolution reaction than the anode prepared from the inorganic oxide sol, due to their larger real surface area; it was also shown that the coating mass on the anode does not influence significantly the anode activity in the chlorine and oxygen evolution reaction at low over potentials. It can be explained that more compact thick coating appears to be more active for the chlorine evolution at higher overpotentials, due to forced micro-convections in the pores (Panić et al, 2003). 
The sol-gel chemistry has recently been involved in a general and powerful approach to preparing inorganic materials, as reported by Lakshmi et al (Lakshmi et al, 1996). The sol-gel method has been proven to be a very flexible and promising means in view of the controlled synthesis of $\mathrm{Au}, \mathrm{Ag}$ and other metal nanoparticle embedded metal oxides, as well as relevant for photocatalytic applications, which includes the synthesis of anatase titanium dioxide, anatase titanium dioxide doped with $\mathrm{La}, \mathrm{Fe}, \mathrm{V}, \mathrm{Au}, \mathrm{Ag}$ and other photocatalytic systems. Metal nanoparticles dopants as $\mathrm{Ag}, \mathrm{Cu}$ and $\mathrm{Au}$ demonstrate a strong absorption band in the visible or near IR spectrum due to plasmin resonance. The position of the plasmin resonance band depends on the size and shape of metallic NP, so the NP plasma resonance control can be adjusted for a useful spectral region, e.g. for the region of the biological tissue transparency (between $\sim 650 \mathrm{~nm}-1200 \mathrm{~nm}$ ). In this region, tissues (blood, bones, skin) are transparent. The metal NP is inert in the biological media, so it can be excited by light $\sim 650 \mathrm{~nm}-1200 \mathrm{~nm}$ if it were injected in the body. It allows, as reported by Huang et al (Huang et al, 2006), carrying out the photo thermal therapy in the nearInfrared Region by using gold-nanorods.

The great interests for antimicrobial effect research of new materials based on the nanosized particles toward pathogens is explained by the increase of new microbiological strains resistant to antibiotics, as well as by the motivation to further study disinfection possibilities of new systems based on nanosized particles. Microbes resistant to silver occur pretty rarely in the nature, which is very important for the application of process of $\mathrm{TiO}_{2}$ photocatalysis using silver ions or silver colloids for disinfection of microbes; therefore, the application of metallic plasmin nanoparticles represents a promising approach to the photothermolysis of bacterial cell or cancer cells. New materials with hybrid nanoparticles made from metallic and wide band semiconductors $\mathrm{TiO}_{2}$ and $\mathrm{ZrO}_{2}$ are suggested for medical and their environmental applications. Further research and studies are aimed at the development of the preparation of hybrid nanoparticles (hNPs) comprised by metal-nanoparticles ( $\mathrm{La}, \mathrm{Fe}, \mathrm{V}, \mathrm{Ag}$, $\mathrm{Au}$, etc.) on the wide band gap semiconductors $\left(\mathrm{TiO}_{2}\right)$ and the study of antimicrobial effects against gram-negative and gram-positive bacteria in dark, under excitation by the visible light and UV-A light. We expected different mechanisms of hNP's action on bacteria under light activation. Effect of hNP's disinfection in dark towards the bacterial films formation will be studied in detail. The hNP's surface modification will be developed in vivo for biomedical applications. The administrated nanoparticles are eliminated from the circulation within seconds to minutes through the 
reticula-endothelial system without surface modifications. Oxide nanoparticles will be obtained by processes such as mechanic-chemical synthesis, hydrothermal method, pyrolysis, plasma-chemical method, solgel technology and precipitation methods. By using zirconium or titanium salt of different nature and different agent-precipitated and various dopants, one can control the structure and the surface state of oxide nanoparticles.

It is well known that the traditional disinfection methods such as chlorine-based technologies lead to the formation of chloroorganic disinfection by-products (DBPs) with carcinogenic and mutagenic effects on mammals (Richardson, 2003); so, it is important to develop advanced disinfection processes and applications for sustainable supply of drinking water. Marugán et al (Marugán et al, 2010) in their study are focused on the evaluation of analogies and differences found when comparing the $\mathrm{TiO}_{2}$ photocatalytic treatment for chemical oxidation and microorganism's inactivation, using methylene blue and Escherichia coli as references, respectively. The activation of both processes is based on the same physicochemical phenomena and consequently a good correlation between them is observed when analyzing the effect of operational variables such as the catalyst concentration or the incident radiation flux. Both factors influence common stages such radiation absorption and generation of reactive oxygen species. However, different microbiological aspects, such as osmotic stress, repairing mechanism, regrowth, bacterial adhesion to the titania surface, etc. make disinfection kinetics significantly more complex than the first-order profiles usually observed for the oxidation of chemical pollutants (Marugán et al, 2010). This study has shown that bacterial inactivation reactions are found to be extremely sensitive to the composition of water and modifications of the catalysts in comparison with the decolorization of the dye solutions, showing opposite behaviors in the presence of chlorides, incorporation of silver to the catalysts or the use of different types of immobilized $\mathrm{TiO}_{2}$ systems. The complex structure of living cells, the existence of several mechanisms for cell regeneration, and the possibility of post-irradiation regrowth could be considered as drawbacks when microorganism inactivation is compared to the oxidation of chemical pollutants; it is, therefore, particularly difficult to model the microbiological aspects involved in the disinfection treatment process (Marugán et al, 2010).

In recent years, researchers in the field of photocatalysis have paid more attention to the study of hybrid nanoparticle systems such as $\mathrm{Ag}$ nanoparticles on the $\mathrm{TiO}_{2}$ surface, which use UV-A light for the excitation of photocatalysts. Photo induced bactericidal activity of nanostructured 
$\mathrm{TiO}_{2}$, and the deposition effect of silver and bimetallic $\mathrm{Ag} / \mathrm{Ni}$ nanoparticles on the pathophysiological properties of titanium films were investigated. The model of microorganisms for antimicrobial activity of films was evaluated against Pseudomonas fluorescents B-22 (gramnegative bacteria) and Lactococcus lactic ssp. lactate 411 (gram-positive bacteria). The silver-modified $\mathrm{TiO}_{2}$ film demonstrates the highest photo biocide efficiency, enhancing the bactericidal activity of UV light cca. 71 times, which results from the radical improvement of microorganism adsorption and suppression of recombination of photo produced charge carriers (Skorb, E.V. et al, 2008). Recently gold-doped $\mathrm{TiO}_{2}\left(\mathrm{Au} / \mathrm{TiO}_{2}\right)$ nanocomposites have been investigated to enhance the photocatalytic efficiency of $\mathrm{TiO}_{2}$ in decomposing organic compounds and photo killing bacteria.

Photocatalytic systems based on hybrid nanoparticles with UV excitation are suggested for the production of new medical products. Ag/titanium dioxide $\left(\mathrm{TiO}_{2}\right)$-coated silicon catheters were easily fabricated with $\mathrm{Ag}$ nanoparticles deposition on both the inside wall and the outside wall of $\mathrm{TiO}_{2}$-coated catheters by the $\mathrm{TiO}_{2}$ photocatalysis. This is an application of the silicon catheters coated with $\mathrm{TiO}_{2}$ which possess a selfsterilizing and self-cleaning property combined with UV light illumination (Ohko et al, 2001). Yao et al (Yao et al, 2008) reported that similarly to $15 \mathrm{nmol} \mathrm{cm} \mathrm{cm}^{-2}$ of Ag, $99 \%$ effective sterilization occurred in a very short time: $20 \mathrm{~min}$ for E. coli, $60 \mathrm{~min}$ for Pseudomonas aeruginosa, and $90 \mathrm{~min}$ for Staphylococcus aureus; the $\mathrm{Ag} / \mathrm{TiO}_{2}$-coated catheters possessed a strong self-cleaning property. The photocatalytic decomposition rate of methylene blue dye using UV illumination representing the self-cleaning capability, on an $\mathrm{Ag} / \mathrm{TiO}_{2}$ catheter which was loaded with $2 \mathrm{nmolcm}$-2 of $\mathrm{Ag}$, was similarly 1.2 times higher (at maximum) than that on the $\mathrm{TiO}_{2}$ coating alone. Furthermore, $\mathrm{Ag}$ nanoparticles can be pre-eminently and uniformly deposited onto the $\mathrm{TiO}_{2}$ coating, and the amount of $\mathrm{Ag}$ was easily controllable from a few nanomoles per square centimeter to 70 nmolcm ${ }^{-2}$ by changing the UV illumination time for the $\mathrm{TiO}_{2}$ photocatalysis. This catheter type shows a great promise in lowering the incidence of catheter-related bacterial infections (Yao et al, 2008).

\section{Experimental}

\section{Material}

Methyl-tertiary-butyl-ether (MTBE, purity $\geq 99.5 \%$ ), hydrogen peroxide $(35 \%)$, methanol $(99.8 \%)$, sodium carbonate $\left(\mathrm{NaCO}_{3}\right)$, ammonium hydroxide $\left(\mathrm{NH}_{4} \mathrm{OH}\right)$ and ethanol (all three purity grades were 
$99.9 \%)$, barium hydroxide octahydrate $\left(\left[\mathrm{Ba}(\mathrm{OH})_{2}+8 \mathrm{H} 2 \mathrm{O}\right], 98 \%\right)$, phenolphthalein, Tryptic Soy Broth (TSB) and Caseinhydrolysate Glucose Yeast extract Broth (Base) were obtained from Merck Millipore, hydrogen chloride (35\%) from Lachema, and sodium hydroxide from Euro Hemija. Titanium dioxides were purchased from Alfa Aesar Lancaster (anatase nanopowder, 99.9\%) and Degussa AG Frankfurt $\left(\mathrm{TiO}_{2}\right.$ powder, $\left.\mathrm{P}-25^{\circledR}\right)$, and used as such. The Pseudomonas aeruginosa strains ATCC 9023 and DV 2739 were used in the experiments researching microbial activity and inactivity. All other chemicals used in the synthesis of catalyst, such as $\mathrm{LaCl}_{3} \cdot 7 \mathrm{H}_{2} \mathrm{O}, \mathrm{FeCl}_{3} \cdot 6 \mathrm{H}_{2} \mathrm{O}, \mathrm{VCl}_{3}$, and $\mathrm{TiCl}_{4}$ were obtained from Merck Millipore as the analytical grade.

\section{Method}

The experimental research in this study consists of the following components:

1. Preparation of catalysts;

2. Characterization of catalysts;

3. Research of photocatalytic activities:

I Experiments of photocatalytic activities; and

II Coupled photocatalytic-microbiological experiments;

4. Research of microbial activity and inactivity:

I Microbial activity and inactivity of coupled photocatalyticmicrobiological experiments; and

II Experiments of antimicrobial activities.

The commercial $\mathrm{TiO}_{2}$ catalysts, as anatase nanopowder and Degussa $\mathrm{P}-25^{\circledR}$, synthetized $\mathrm{TiO}_{2}$-nanoparticles catalysts (calcination duration of 5 and $7 \mathrm{~h}$ ), and synthetized $\mathrm{TiO}_{2}$ nanoparticles based catalysts doped with different concentrations of following metals: $\mathrm{La}^{3+}(0.65,1,2$, $3,4,5$ and 6 wt. \%), $\mathrm{Fe}^{3+}(1,2.5,3.0$ and 5 wt. \%, with calcination duration of 7 and $24 \mathrm{~h})$, and $\mathrm{V}^{3+}(10 \mathrm{wt}$. \%, with calcination duration of 7 and $24 \mathrm{~h}$ ); were tested in the photocatalytic, coupled photocatalyticmicrobiological and antimicrobial activities for different concentrations of the MTBE water solution. These experiments were performed in a slurrycatalyst bath circulation photoreactor in the presence of direct ultraviolet (UV) radiation simulated with a sodium lamp SONT UV400 in lab conditions. Also, both commercial titania (Degussa P-25 ${ }^{\circledR}$ and anatase powder, purity: $99.9 \%$ ), synthetized $\mathrm{TiO}_{2}$ nanoparticles (synthesized at $550{ }^{\circ} \mathrm{C}$ with a calcination duration of $5 \mathrm{~h}$ ), $\mathrm{TiO}_{2}$ nanoparticles doped $\mathrm{La}^{3+}$ ( 5 wt. \%, with a calcination duration of $7 \mathrm{~h}$ ) and $\mathrm{Fe}^{3+}$ ions $(2.5$ wt. \%, with a calcination duration of $7 \mathrm{~h}$ ) were tested in the antimicrobial activity 
experiments. $\mathrm{TiO}_{2}$-nanoparticles and their dopants catalysts were synthetized and characterized before our experiments. Pseudomonas aeruginosa strain ATCC 9023 was used as a model microorganism in the coupled photocatalytic-microbiological and first antimicrobial activity experiments, and Pseudomonas aeruginosa strain DV 2739 was used as a model microorganism in the second antimicrobial activity experiments. The antimicrobial activity experiments were performed in a microbiological cabinet. The experiments are very important for the determination of the microorganism toxicity point with $\mathrm{TiO}_{2}$ nanoparticle catalysts, i.e. the concentration at which the release of microorganisms occurrs.

\section{Photoreactor}

The photocatalytic and coupled photocatalytic-microbiological experiments in the MTBE water solution were tested in a bath slurrycatalyst circular photoreactor (Fig.1). The photoreactor consisted of a 92 $\mathrm{cm}$ long quartz tube (inner diameter $19 \mathrm{~cm}$ and outer diameter $21 \mathrm{~cm}$ ), and slurry circulated through the system by the pump, from the storage tank through the control valve and the reactor, and back to the storage tank that is thermo stated at $30{ }^{\circ} \mathrm{C}$. This set-up of the system provided uniform distribution of the photo catalyst. The storage tank has a volume of 2 liters, which is operational in full capacity for all experiments.

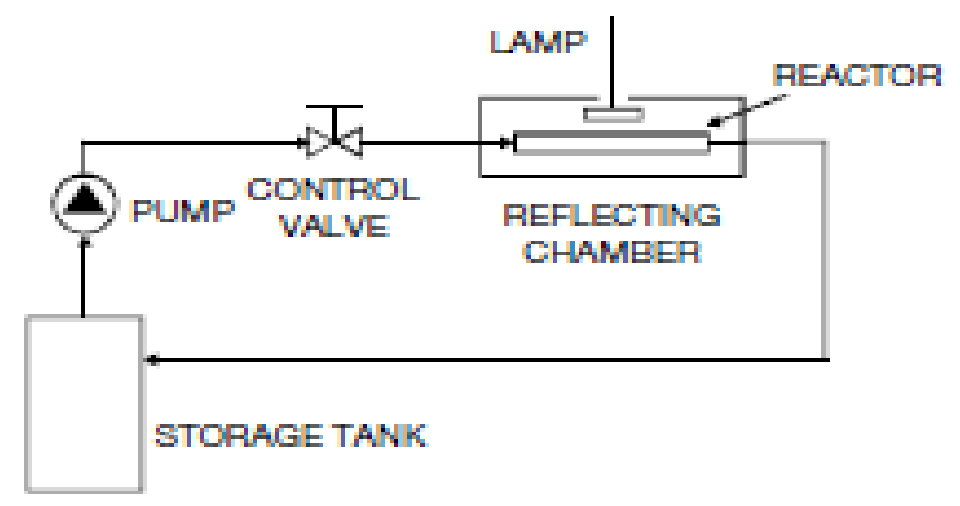

Figure 1 - Experimental apparatus for the photocatalytic and coupled photocatalyticmicrobiological experiments

Puc. 1 - Экспериментальная аппаратура для фотокаталитического и комбинационного фотокаталитично-микробиологического эксперимента Слика 1 - Експериментална апаратура за фоотокаталитички и комбиновани фотокаталитичко-микробиолошки експеримент 
The ultraviolet radiation needed for the photoreaction in the experiments was provided by a sodium lamp, SON-T UV400. The lamp produced a photon flux of $960 \mu \mathrm{molm}^{-1} \mathrm{~s}^{-2}$ in two different wavelength intervals: $380-518 \mathrm{~nm}$ and $540-800 \mathrm{~nm}$, as well as at the local maximum at $333 \mathrm{~nm}$. The distance between the reactor and the sodium lamp was $17 \mathrm{~cm}$. The reactor was in a chamber with the reflecting aluminum foil inner walls in order to provide a uniform UV radiation pattern and intensity for the experiments.

\section{MTBE as a model compound}

Methyl-tertiary-butyl-ether (MTBE) has been used as a high constituent and as a replacement for the anti-knocking agent (tetra ethyl lead) of gasoline since the late 1970s. MTBE is a colorless, transparent and flammable liquid whose harmful effects on the environment and the ecosystem have been confirmed over time. It is one of the most dangerous pollutants for human health in the environment; it is frequently detected in wastewater, groundwater, watercourses, drinking water and the soil. The purification and bioremediation of MTBE polluted groundwater is very slow; it is particularly difficult to treat, due to high MTBE solubility in the water $(48.000 \mu \mathrm{g} / \mathrm{L})$ and its low volatility (The Merck index, 1996), (Shaffer \& Uchrin, 1997). Also, The EPA characterized MTBE as a potential cancerogenic compound in the environment and suggested the concentration limit of $20-40 \mu \mathrm{g} / \mathrm{L}$ for the compound in drinking water (Squillace et al, 1996), (Pontius, 1998). Also, the California Department of Health Services has adopted $5 \mu \mathrm{g} / \mathrm{L}$ as the maximum MTBE concentration levels (California Code of Regulations, 1999).

\section{Catalyst preparation}

The sol-gel method was used for the synthesis of pure and doped anatase nanopowders with iron $\left(\mathrm{Fe}^{3+}\right)$, lanthanum $\left(\mathrm{La}^{3+}\right)$ and vanadium ion $\left(\mathrm{V}^{3+}\right)$. Titanium (IV) chloride ( $\mathrm{TiCl}_{4}, 99.0 \%$ pure, Merck) was used as the precursor in the synthesis process. Hydrogel, titanium (IV) hydroxide $\mathrm{Ti}(\mathrm{OH})_{4}$, was obtained by the hydrolysis of $\mathrm{TiCl}_{4}$ at $0^{\circ} \mathrm{C}$ with a controlled addition of $2.5 \mathrm{wt}$. \% aqueous ammonia into the aqueous solution of $\mathrm{TiCl}_{4}$ $(0.3 \mathrm{moll} / \mathrm{l})$ and a careful control of the solution's $\mathrm{pH}$ value of 9.3 for pure $\mathrm{TiO}_{2}$ nanoparticles, as well as $\mathrm{La}, \mathrm{Fe}$ and $\mathrm{V}$-dopants of $\mathrm{TiO}_{2}$ nanoparticles (Golubović et al, 2009a), (Grujić-Brojčin et al, 2014). $\mathrm{TiCl}_{4}$ is soluble in water but it experiences rigorous reaction at $20^{\circ} \mathrm{C}$ which can be very important when performing this reaction at a lower temperature. After aging in the mother liquor for $5 \mathrm{~h}$, the as-prepared hydrogel was 
filtered and washed out with distilled water until complete removal of chlorine ions. The obtained $\mathrm{Ti}(\mathrm{OH})_{4}$ hydrogel was converted to its ethanol gel by repeated exchanges with anhydrous ethanol for several times (by repeated introduction of anhydrous ethanol). The obtained Alco gel represents the starting point for the production of $\mathrm{TiO}_{2}$ nanoparticles. Alco gel was placed in a vessel, dried at $280^{\circ} \mathrm{C}$ and calcined at a temperature of $550^{\circ} \mathrm{C}$ for 5,7 and $24 \mathrm{~h}$ (depending of the sample types); after that, it was converted to nanoparticles. Dopants were in the form of chloride $\left(\mathrm{LaCl}_{3} \cdot 7 \mathrm{H}_{2} \mathrm{O}\right.$ and $\mathrm{FeCl}_{3} \cdot 6 \mathrm{H}_{2} \mathrm{O}$ and $\left.\mathrm{VCl}_{3}\right)$ and mixed with $\mathrm{TiCl}_{4}$ in the adequate ratio before hydrolysis.

The heating rate, duration of calcination for pure (S05, S06, S07, S08, S10, S11, S99 and S102), La-doped (S16, S18, S28, S38, S40a, S48, S52a and S64), Fe-doped (S24, S111-S112, S117-S120), V-doped (S93 and S96) and their different wt. \% of $\mathrm{TiO}_{2}$ dopants samples are specified in Table 1 at the Result and Discussion Section: Synthesis conditions. All samples except S05, S06, S10, S99 and S102 samples were used to test photocatalytic, microbiological and antimicrobial activities, while these pure titania nanoparticles were used for a comparative analysis in accordance with their temperature profile.

\section{Characterization of the catalysts}

X-Ray Power Diffraction (XRPD) was used for the identification of the crystalline phases, the quantitative phase analysis and the estimation of the crystallite size and strains, as explained earlier (Golubović et al, 2009a), (Grujić-Brojčin et al, 2014). The XRPD patterns for $\mathrm{TiO}_{2}$ nanoparticles for pure samples (S07, S08 and S10) and La-dopants with 0.65 and 1 moll \% of lanthanum ions (S18 and S28 samples) have been collected on a Philips diffract meter (PW1710) employing $\mathrm{Cu} \mathrm{K}_{\alpha 1,2}$, in the scanning range of $2 \theta$ between 20 and $80^{\circ}$ with the step size of $0.06^{\circ}$ and the counting time of $41 \mathrm{~s} / \mathrm{step}$. Higher La-dopants concentrations of titanium (IV) dioxide nanoparticle patterns, such as in S52a (4 wt. \%) and S64 (6 wt. \%) samples, have been collected in the same range by using a Stoe Stadi MP diffract meter $\left(\mathrm{Cu} \mathrm{K}_{\alpha 1}\right.$ radiation, primary beam germanium monochromatic linear PSD detector, Bragg-Brentano geometry), at every $0.01^{\circ}$, with a counting time of $80 \mathrm{~s} / \mathrm{step}$. A full-prof computer program was used for the structure refinements, the quantitative phase analysis and the estimation of the average crystallite size and strains (Rodriguez-Carvajal, 2008). The instrumental resolution function for the size-strain analysis was obtained by parameterizing the 
profiles of the diffraction pattern of an $\mathrm{LaB}_{6}$ (NIST SRM660a) standard specimen.

The composition/quality of $\mathrm{TiO}_{2}$ nanoparticles patterns of the samples such as S06 and S11, as well as their following La-dopants patterns ofS18, S28, S40a and S64 samples was analysed on a SEM (JOEL JSM-6460LV, with the operating voltage of $20 \mathrm{keV}$ ) equipped with the EDS (INCAx-sight) detector and the "INAx-stream" pulse processor (Oxford instruments).

An Atomic Force Microscope - AFM (Omicron B002645 SPM PROBE VT AFM 25) in the contact mode was used to create an image of the surface topology of the $\mathrm{TiO}_{2}$ nanoparticles doped: La-dopant as S18 pattern and Fe-dopant S111 patterns of the samples.

The porous structure of the catalysts has been evaluated from the adsorption/desorption isotherms of $\mathrm{N}_{2}$ measured on the $\mathrm{TiO}_{2}$ samples such as S05, S06, S11, S18, S28 and S40a at $136^{\circ} \mathrm{C}$ using the gravimetric McBain method. The main parameters of porosity such as the specific surface area and the pore volume have been estimated by the BET method and the $\alpha_{s}$-plot, as reported by Kaneko et al (Kaneko et al, 1998) and the references therein. The pore size distributions have been estimated from the experimental nitrogen sorption data by the $\mathrm{BJH}$ and CPSM methods (Golubović et al, 2013), (Barrett et al, 1951).

The Raman scattering measurements of the chosen $\mathrm{TiO}_{2}$ nanoparticles patterns of samples such as S11, S99 and S102 and their doped patterns of samples such as S48, S93 and S96 were performed in the backscattering geometry at room temperature in the air using a Jobin-Yvon T64000 triple spectrometer, equipped with a confocal microscope and a nitrogen-cooled charge coupled device detector. To avoid local heating due to laser irradiation, the spectra have been excited by a $514.5 \mathrm{~nm}$ line of $\mathrm{Ar}^{+} / \mathrm{Kr}^{+}$ion laser with an output power of less than $5 \mathrm{~mW}$.

\section{Measurement of photocatalytic activities}

The photocatalytic activities of $\mathrm{TiO}_{2}$ (commercial and synthetized nanoparticles) and their $\mathrm{La}^{3+}, \mathrm{Fe}^{3+}$ and $\mathrm{V}^{3+}$ dopants were evaluated by the degradation of the MTBE water solution. The photocatalytic degradation of the water polluted by MTBE in lab conditions was carried out as described in our previous research, as reported by Kuburovic et al (Kuburovic et al, 2005, 2007, 2009) and presented at a conference (Kuburovic \& Orlovic, 2010) as a part of the Preliminary study of photocatalytic wastewater treatments conducted in lab conditions using water samples from the Belgrade sewage system. 
The photocatalytic activity measurement was performed in two types of experiments: the photocatalytic experiments and the coupled photocatalytic-microbiological experiments. The photocatalytic experiments were carried out in the presence of $\mathrm{TiO}_{2}$ (commercial and synthetized nanoparticles) and their dopant catalysts.

The stock solution for the first experiment type (photocatalytic experiment) was prepared by stirring $2 \mathrm{ml}$ of MTBE with $8 \mathrm{ml}$ of ethanol (both Merck Millipore). The prepared stock solution was mixed with distilled water (2L volume) from which $10 \mathrm{ml}$ of water was extracted for all photocatalytic experiments.

The stock solution for the second experiment type (coupled photocatalytic-microbiological experiments) was prepared by stirring $1 \mathrm{ml}$ of MTBE with $9 \mathrm{ml}$ of ethanol (both Merck Millipore). The prepared stock solution was mixed with distilled water (2L volume) from which $30 \mathrm{ml}$ of water was extracted in two steps: in the first step, $10 \mathrm{ml}$ of water was extracted, added to the stock solution and mixed; in the second step, 20 $\mathrm{ml}$ of water solution was extracted followed by the addition of $20 \mathrm{ml}$ of the microorganism (MO) Pseudomonas aeruginosa strain ATCC 9023 in a

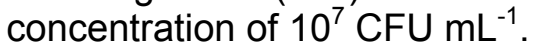

The resulting water solution (in both experiments, with the $\mathrm{MO}$ and without it) of MTBE was poured into the photoreactor and thus prepared for each experiment. Each experiment began with a circulation in the photoreactor and the burning of the UV lamp. When the photoreactor started to work in the uniform mode, 10 minutes after the beginning, the experiment was started with zero time. After the completion of the experiment, the reactor was thoroughly washed and sterilized, and after that prepared for the next experiment. The method of preparing the MO for the coupled photo catalytic-microbiological experiments was explained in the part entitled Measurements of the Microbiological Growth.

The GC-MS determinations in the photocatalytic activity experiments were carried out on an Agilent Technologies gas chromatographer equipped with a mass detector using the headspace (GC/MSD/Headspace - 7890A/5975C/G1888). Nitrogen was used as a carrier gas.

The total oxigen carbon (TOC) analysis was carried out by the AstroZellwenger LabToc-2100 as in the previous research the results of which are compared in the study.

The kinetics of $\mathrm{CO}_{2}$ evoultion during the photocatalytic activity experiment for titania nanopowders Fe-dopants consisted of flushing the $\mathrm{CO}_{2}$ produced by oxygen into a flask containing a $10^{-2} \mathrm{M}$ of $\mathrm{Ba}(\mathrm{OH})_{2}$ 
solution followed by titration with a $0.001 \mathrm{~N} \mathrm{HCl}$ solution. Phenolphtalein was used as an indicator.

The quantification of the bacterial cultures from all tested solutions in microbiological activity and inactivity during the coupled photocatalyticmicrobiological experiments was carried out on the Shimatzu Cary "UV 1700" UV-VIS spectrophotometer, and for the antimicrobial activity, the experiments were carried out on a calorimeter analog photo calorimeter, Labtronics, India.

\section{Measurement of the microbiological growth}

The research of microbial activity and inactivity can be conducted with the measurements of the microbiological growth using optical density. The methodology of both experiments is presented in the text below.

Microbial activity and inactivity of the coupled photocatalytic-microbiological experiments

Our research of the microorganism activity from the coupled photocatalytic-microbiological experiments was performed on the model microorganism (MO) Pseudomonas aeruginosa strain ATCC 9023 in the presence and without $\mathrm{TiO}_{2}$-nanoparticles and their $\mathrm{La}, \mathrm{Fe}$ and $\mathrm{V}$-dopants at the batch slurry-catalyst circular photoreactor.

The MO model was a fresh bacterial culture of around $10^{9} \mathrm{CFU} \mathrm{mL}{ }^{-1}$ of a stationary concentration prepared by the inoculation of $100 \mathrm{~mL}$ Tryptic Soy Broth (TSB) enriched with $0.6 \%$ of Caseinhydrolysate Glucose Yeast extract Broth (Base) (both Merck Millipore) and aerobic incubation at $37^{\circ} \mathrm{C}$ under rotary shaking for $24 \mathrm{~h}$. We thus obtained an TSB enriched substrate for the experiment and the zero control samples $\left(k_{0}\right)$. After that, the TSB enriched base substrate in a volume of $20 \mathrm{~mL}$ was additionally enriched with a $0.5 \mu \mathrm{l} / \mathrm{ml}$ of the MTBE stock solution (as the first control sample $-k_{1}$ ) and centrifuged for each experiments and rinsed twice with sterile ultrapure water (Milli-Q, 18.2 M $\Omega \mathrm{cm}$ ) before diluting $20 \mathrm{~mL}$ of the resultant bacterial suspension to $2 \mathrm{~L}$ to prepare the reacting suspensions, with an initial concentration of viable bacteria

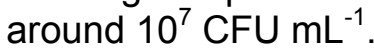

The experiment started 10 minutes (contact time) after mixing the water solution of MTBE with the $20 \mathrm{~mL}$ prepared MO, Pseudomonas strain ATCC $9023\left(10^{7} \mathrm{CFU} \mathrm{mL}^{-1}\right)$, testing catalysts, at the batch slurrycatalyst circular photoreactor and switching the recirculation pump. The photocatalytic experiments were followed during 150 minutes, depending 
on the experiment. The contact time was necessary for the habituation of the MO on the MTBE solution and the catalyst, as well as for preparing the uniform sodium lamp to work.

The quantification of Pseudomonas aeruginosa strain ATCC 9023 from all tested solutions has been determined on the Shimatzu Cary "UV 1700" UV-VIS spectrophotometer at $550 \mathrm{~nm}$. Optical density was also measured when each component (MTBE water solution, MO, catalyst) was added to the MTBE water solution after mixing in the photoreactor. In this experiment, an increase in the absorption of the solution to 648 $\mathrm{nm}$ was observed, as a measure of increase of the MO growth and its microbiological activity.

\section{Experiments of the antimicrobial activities}

Pseudomonas aeruginosa strains ATCC 9023 and DV 2739 were used as model microorganisms for the experiments on antimicrobial activities, performed in a microbiological cabinet. Namely, Pseudomonas aeruginosa strain ATCC 9023 was used earlier for our preliminary research, the results of which were presented as an oral presentation by Kuburovic (Kuburovic \& Dimitrijevic-Brankovic, 2006) at the EMEC7 Conference, but they have not been published yet. After our preliminary study, Pseudomonas aeruginosa strain DV 2739 was used in all other experiments on antimicrobial activities.

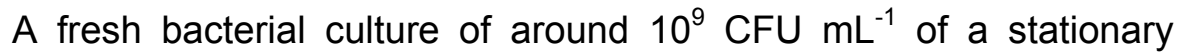
concentration was prepared for both experiments, by the inoculation of $50 \mathrm{~mL}$ Triptyc Soy Broth (TSB) enriched with $0.6 \%$ Casein hydro lysate Glucose Yeast extract Broth (Base) (both Merck Millipore) and aerobic incubation at $37^{\circ} \mathrm{C}$ under rotary shaking for $24 \mathrm{~h}$. We thus obtained an TSB enriched base substrate for the experiments and the zero control samples $\left(\mathrm{k}_{0}\right)$, which was seeded individually on the following samples:

I Premilinary research: The volume of $2.0 \mathrm{ml}$ of the TSB enriched base substrate for each of five samples was seeded with different concentrations of the MTBE stock solution of $0.15 ; 0.25 ; 0.5 ; 1.0$ and $2.0 \mu \mathrm{l} / \mathrm{ml}$, respectively. Also, the volume of $2.0 \mathrm{ml}$ of the TSB enriched base substrate was seeded for three new samples with the $0.5 \mu \mathrm{l} / \mathrm{ml}$ of MTBE stock solution with $0.1 \mathrm{~g} / \mathrm{L} \mathrm{TiO}$ (anatase $\mathrm{TiO}_{2}$ nanoparticles, $99.9 \%$, Alfa Aesar Lancaster), $\mathrm{FeCl}_{3}$ in a concentration of $5 \mu \mathrm{l} / \mathrm{ml}$ and the catalyst-reagent system $\mathrm{TiO}_{2}$ and $\mathrm{FeCl}_{3}$ in the ratio of $1: 1$ in the concentration of $5 \mu \mathrm{l} / \mathrm{ml}$, respectively. All such prepared samples were centrifuged for each experiment and rinsed twice with sterile ultrapure water (Milli-Q, 
18.2 $\mathrm{M} \Omega \mathrm{cm}$ ) before diluting $2 \mathrm{~mL}$ of the resultant bacterial suspension to prepare the initial concentration of viable bacteria of

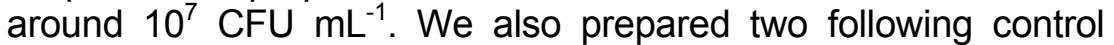
samples for each experiment: the TSB enriched base substrate (without anything else) and the TSB enriched base substrate that was seeded with an initial concentration of $0.50 \mu \mathrm{l} / \mathrm{ml}$ of the MTBE stock solution;

II Antimicrobial activity research: The volume of $2.0 \mathrm{ml}$ of the TSB enriched base substrate was seeded for twenty-four samples (6 samples in 4 different concentrations) with $0.5 \mu \mathrm{l} / \mathrm{ml}$ of the MTBE stock solution with different concentrations of $\mathrm{TiO}_{2}$ nanoparticle catalysts such as: comercial $\mathrm{TiO}_{2}$ (anatase, $99.9 \%$, Alfa Aesar Lancaster) and P-25 (Degussa P-25 ${ }^{\circledR}$ ), synthetized as pure $\mathrm{S} 11$ sample and doped $\mathrm{TiO}_{2}$ nanoparticles sample, S16 (La-dopant) and S24 (Fe-dopant), as well as the catalyst-reagent system of $\mathrm{TiO}_{2}$ and $\mathrm{FeCl}_{3}$ in the ratio of $1: 1$ in the concentration of $5 \mu \mathrm{l} / \mathrm{ml}$, respectively; each in several concentrations: $0.05,0.10,0.20$ and $0.25 \mathrm{mg} / \mathrm{L}$. All such prepared samples were centrifuged for each experiment and rinsed twice with sterile ultrapure water (Milli-Q, $18.2 \mathrm{M} \Omega \mathrm{cm}$ ) before diluting $2 \mathrm{~mL}$ of the resultant bacterial suspension to prepare the initial concentration of viable bacteria of

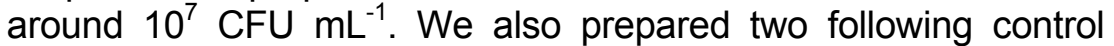
samples for each experiment: the TSB enriched base substrate (without anything else) and the TSB enriched base substrate that was seeded with the initial concentration of $0.50 \mu \mathrm{l} / \mathrm{ml}$ of the MTBE stock solution;

The MTBE stock solution for both experiment types was prepared by stirring $1 \mathrm{ml}$ of MTBE (Merck Millipore) with $9 \mathrm{ml}$ of ultrapure water (Milli$\mathrm{Q}, 18.2 \mathrm{M} \Omega \mathrm{cm}$ ) without ethanol, which gave the MTBE concentration of $0.50 \mu \mathrm{l} / \mathrm{ml}$. The photo activity of the catalysts on Pseudomonas aeruginosa strains ATCC 9023 and DV 2739 in both experiments was investigated in a microbiological chamber illuminated sample with an UVA lamp at $366 \mathrm{~nm}$.

The quantification of Pseudomonas aeruginosa strains ATCC 9023 and DV 2739 from all tested solutions has been performed on an analog photocolorimeter (Labtronics, India) at $550 \mathrm{~nm}$. In this experiment, a reduction in the absorption of the solution to $648 \mathrm{~nm}$ was observed, as a measure of decrease of the MO growth and their antimicrobial activity. 


\section{Results and Discussion}

\section{Synthesis conditions}

The properties of the synthetized pure and doped titanium (IV) oxide nanoparticles by the sol-gel method synthesis determined the main of the following parameters: the $\mathrm{pH}$ value in the hydrolysis process, the precursor type, the temperature and the duration of hydrolysis (aging) and drying, and Alco gel. The most important are the ones of the calcination process parameters: heating rate, temperature, calcination cooling and duration rate. Titanium (IV) chloride $\left(\mathrm{TiCl}_{4}\right)$, as a cheap compound, is the primary starting material for the commercial production of titanium powders. The sol-gel method synthesis entails the hydrolysis of a precursor molecule solution aiming to obtain first a suspension of colloidal particles - the sol and then a gel composed of aggregated sol particles, which is in the further processing thermally treated yielding to the desired nanoparticles material. The process takes the following direction:

$$
\mathrm{TiCl}_{4} \rightarrow \mathrm{Ti}(\mathrm{OH})_{4} \rightarrow \text { Alco gel }
$$

This reaction can be written in a chemical way as

$$
\begin{aligned}
& \mathrm{TiCl}_{4}+4 \mathrm{NH}_{4} \mathrm{OH} \rightarrow \mathrm{Ti}(\mathrm{OH})_{4} \downarrow+4 \mathrm{NH}_{4} \mathrm{Cl} \\
& \mathrm{Ti}(\mathrm{OH})_{4} \rightarrow \mathrm{TiO}_{2}+2 \mathrm{H}_{2} \mathrm{O}
\end{aligned}
$$

The $\mathrm{pH}$ value of the precursor solution is a decisive factor in controlling the final particle size and shape, the crystal phase and the agglomeration (Zhang \& Sun, 2004) due to its crucial influence on the relative rates of hydrolysis and polycondensation. Aruna et al (Aruna, et al, 2000) have found that the main hydrolysate in this reaction is $\left[\mathrm{Ti}(\mathrm{OH})_{n}(\mathrm{H} 2 \mathrm{O})_{6-n}\right]^{(4-n)+}$, where the amount of water varies with the relative rates of hydrolysis and polycondensation.

The titanium monomers formed during the reaction in the precursor solution play a significant role in the condensation process (Sun, J., et al. 2002) and in the formation of the final gel structure containing precursor molecules (Díaz-Díez, M.Á., et al, 2003). Since the intention was to obtain $\mathrm{TiO}_{2}$ nanoparticles in the anatase form, the $\mathrm{pH}$ value of the solution during the hydrolysis process was chosen to be 9.3 which is in accordance with the $\mathrm{pH}$ value of 9.4 used by Venz et al (Venz, P.A. et al. 2000) for the same sol state and tetra isopropyl titanate used as a precursor. The $\mathrm{pH}$ value is several $\mathrm{pH}$-units above the $\mathrm{pH}$ value where 
the zeta-potential is zero (isoelectric point), as shown by Venz et al (Venz, P.A. et al. 2000). This is suitable for obtaining the stable sol with the maximum reduction of particle aggregation.

Aging is a process during which the gel properties can be changed as a result of polymerization, coarsening and phase transformation as reported by Wang et al (Wang et al, 2012). The nano crystallite growth presents the coalescence of small neighboring crystallites that become oriented due to the atomic diffusion or discrete orientation attachment. The aging conditions were the same in all experiments, with the temperature of $0^{\circ} \mathrm{C}$ and the process duration of $5 \mathrm{~h}$. This is in accordance with the literature data (He, D. et al. 2007; Hari-Bala, G.Y., et al. 2006). The influence of aging on the properties of synthetized anatase nanoparticles was thus eliminated.

Titanium hydroxide was dried and calcined at high temperature, in order to obtain crystalline $\mathrm{TiO}_{2}$-nanoparticles by the sol-gel method synthesis. In our experiment, as shown by Golubovic et al (Golubović et al, 2009a), the drying temperature was always $280^{\circ} \mathrm{C}$, while the process duration was $4 \mathrm{~h}$. The influence of the calcination parameters on the physical-chemical properties of anatase nanopowders and their dopants was examined by changing the heating rates $\left(55,67.5\right.$ and $\left.135^{\circ} \mathrm{C} / \mathrm{h}\right)$ and their influence of three different calcination durations $(5,7$ and 24$)$ with the constant of the calcination temperature $\left(550^{\circ} \mathrm{C}\right)$ and their cooling rate $\left(37.42^{\circ} \mathrm{C} / \mathrm{h}\right)$. Only S07 sample was synthesized with a little different value of the calcination temperature and the cooling rate from all other samples, at $500^{\circ} \mathrm{C}$ and $37.42^{\circ} \mathrm{C} / \mathrm{h}$ respectively, which can be seen in Table 2.

Some of the sol-gel synthesis parameters for the chosen $\mathrm{TiO}_{2}$ samples (pure and doped), which are the subject of this paper are listed in Table 1.

The temperature profiles for pure $\mathrm{TiO}_{2}$-nanoparticles of $\mathrm{S} 05, \mathrm{~S} 06$, S07, S08, S10, S11, S99 and S102 samples (Table 2) were obtained, investigated and reported earlier (S07, S08 and S10, as A2, A3 and A6 profile samples; S05 and S06, S99 and S102 with a calcination duration of 5, 7 and 24 h, respectively): Golubovic et al (Golubović et al, 2009a), (Golubovic et al, 2013) and Scepanovic et al (Šćepanović et al, 2010) without S11 sample that is here for the comparison purposes.

During the sol-gel synthesis, we prepared pure and doped $\mathrm{TiO}_{2}$ nanoparticles. Based on the presented synthesis data in Tables 1 and 2, the models of the sample temperature profiles for pure $\mathrm{TiO}_{2}-\mathrm{NPs}, \mathrm{S} 05$, S06, S07, S08, S10 and S99 and their dopants are shown in the text bellow. 
Table 1 - Selected parameters for pure $\mathrm{TiO}_{2}-\mathrm{NPs}$ and their $\mathrm{La}^{3+}, \mathrm{Fe}^{3+}$ and $\mathrm{V}^{3+}$ dopants Таблица 1 - Выбранные праметры чистых $\mathrm{TiO}_{2}-\mathrm{H} 4$ и uх $\mathrm{La}^{3+}, \mathrm{Fe}^{3+} \mathrm{u} \mathrm{V}^{3+}$ допантов Табела 1 - Одабрани параметри за чисте $\mathrm{TiO}_{2}-\mathrm{H}$-е и њихове $\mathrm{La}^{3+}, \mathrm{Fe}^{3+} \mathrm{u} \mathrm{V}^{3+}$ допанте

\begin{tabular}{|c|c|c|c|c|c|c|c|}
\hline \multirow{2}{*}{$\begin{array}{l}\text { Pure } \\
\mathrm{TiO}_{2}-\mathrm{NPS}\end{array}$} & \multirow{2}{*}{$\begin{array}{l}\text { La-doped } \\
\mathrm{TiO}_{2}-\mathrm{NPs}\end{array}$} & \multirow{2}{*}{$\begin{array}{l}\text { Fe-doped } \\
\mathrm{TiO}_{2}-\mathrm{NPs}\end{array}$} & \multirow{2}{*}{$\begin{array}{l}\text { V-doped } \\
\mathrm{TiO}_{2}-\mathrm{NPs}\end{array}$} & \multirow{2}{*}{$\begin{array}{l}\text { wt. \% } \\
\text { dopant }\end{array}$} & \multicolumn{3}{|l|}{ Calcination } \\
\hline & & & & & $\begin{array}{l}\text { Heating } \\
\text { rate }\left[{ }^{\circ} \mathrm{C} / \mathrm{h}\right]\end{array}$ & $\mathrm{T}\left[{ }^{\circ} \mathrm{C}\right]$ & $\begin{array}{l}\mathrm{t} \\
{[\mathrm{h}]}\end{array}$ \\
\hline S05 & & & & & 55 & 550 & 5 \\
\hline S06 & & & & & 55 & 550 & 7 \\
\hline S07 & & & & & 55 & 500 & 7 \\
\hline S08 & & & & & 55 & 550 & 7 \\
\hline S10 & & & & & 135 & 550 & 7 \\
\hline \multirow[t]{12}{*}{$\mathrm{S} 11$} & & & & & 55 & 550 & 5 \\
\hline & S16 & & & 5.0 & 67.5 & 550 & 7 \\
\hline & S18 & & & 0.65 & 67.5 & 550 & 7 \\
\hline & & S24 & & 2.5 & 135 & 550 & 7 \\
\hline & $\mathrm{S} 28$ & & & 1.0 & 135 & 550 & 7 \\
\hline & S38 & & & 5.0 & 135 & 550 & 7 \\
\hline & S40a & & & 2.0 & 135 & 550 & 7 \\
\hline & S48 & & & 3.0 & 135 & 550 & 7 \\
\hline & S52a & & & 4.0 & 135 & 550 & 7 \\
\hline & S64 & & & 6.0 & 135 & 550 & 7 \\
\hline & & & S93 & 10 & 67.5 & 550 & 7 \\
\hline & & & S96 & 10 & 135 & 550 & 24 \\
\hline S99 & & & & & 67.5 & 550 & 7 \\
\hline \multirow[t]{7}{*}{ S102 } & & & & & 135 & 550 & 24 \\
\hline & & S111 & & 5.0 & 135 & 550 & 7 \\
\hline & & $\mathrm{S} 112$ & & 5.0 & 135 & 550 & 24 \\
\hline & & S117 & & 1.0 & 135 & 550 & 7 \\
\hline & & $\mathrm{S} 118$ & & 1.0 & 135 & 550 & 24 \\
\hline & & S119 & & 3.0 & 135 & 550 & 7 \\
\hline & & S120 & & 3.0 & 135 & 550 & 24 \\
\hline
\end{tabular}

Pure and dopants of the model of the S07 sample temperature profile:

These samples were not doped, they were synthesized as S05, S06, S07 and S11 samples, all four with this temperature profile; the only differences between the samples are that S11 sample has a shorter calcination duration of 5 hours (than the calcinatin duration of $7 \mathrm{~h}$ for the other three samples), and that only S07 sample has a lower cooling temperature $\left(500^{\circ} \mathrm{C}\right.$, and for the other three is $\left.550^{\circ} \mathrm{C}\right)$ 
Table 2 - The parameters of the sol-gel process for the same $\mathrm{TiO}_{2}-\mathrm{NPs}$ samples (Golubović et al, 2009a), (Golubović et al, 2013) and (Šćepanović et al, 2010). Only S11 sample has not been reported earlier

Таблица 2 - Параметры золь-гель процесса по тем же образцам $\mathrm{TiO}_{2}-\mathrm{H} 4$ (Golubović et al, 2009a), (Golubović et al, 2013) u (Šćepanović et al, 2010). He был опубликован только образец С11

Табела 2 - Параметри сол-гел процеса за исте узорке TiO 2 -H4-a (Golubović et al, 2009a), (Golubović et al, 2013) u (Šćepanović et al, 2010). Само узорак C11 нuје објављен раније

\begin{tabular}{|l|l|l|l|l|l|l|l|l|l|}
\hline \multirow{2}{*}{$\begin{array}{l}\text { Sam- } \\
\text { ple }\end{array}$} & \multicolumn{3}{|l|}{ Aging } & \multicolumn{3}{l|}{ Drying } & \multicolumn{3}{l|}{ Calcination } \\
\cline { 2 - 10 }$[\mathrm{h}]$ & $\mathrm{T}\left[{ }^{\circ} \mathrm{C}\right]$ & $\begin{array}{l}\text { Dura- } \\
\text { tion }[\mathrm{h}]\end{array}$ & $\mathrm{T}\left[{ }^{\circ} \mathrm{C}\right]$ & $\mathrm{t}[\mathrm{h}]$ & $\begin{array}{l}\text { Heat. } \\
\text { rate }\left[{ }^{\circ} \mathrm{C} / \mathrm{h}\right]\end{array}$ & $\mathrm{T}\left[{ }^{\circ} \mathrm{C}\right]$ & $\mathrm{t}[\mathrm{h}]$ & $\begin{array}{l}\text { Cooling rate } \\
{\left[{ }^{\circ} \mathrm{C} / \mathrm{h}\right]}\end{array}$ \\
\hline $\mathrm{S} 05$ & 5 & 0 & 2 & 280 & 4 & 55 & 550 & 5 & 37.42 \\
\hline S06 & 5 & 0 & 2 & 280 & 4 & 55 & 550 & 7 & 37.42 \\
\hline S07 & 5 & 0 & 2 & 280 & 4 & 55 & 500 & 7 & 36.46 \\
\hline S08 & 5 & 0 & 2 & 280 & 4 & 55 & 550 & 7 & 37.42 \\
\hline S10 & 5 & 0 & 2 & 280 & 4 & 135 & 550 & 7 & 37.42 \\
\hline S11 & 5 & 0 & 2 & 280 & 4 & 55 & 550 & 5 & 37.42 \\
\hline S99 & 5 & 0 & 2 & 280 & 4 & 67.5 & 550 & 7 & 37.42 \\
\hline S102 & 5 & 0 & 2 & 280 & 4 & 135 & 550 & 24 & 37.42 \\
\hline
\end{tabular}

Pure and dopants of the model of the S08 sample temperature profile:

- Dopants of lanthanum: S16 (wt. $5.0 \%$ ) and S18 (wt. $0.65 \%$ ) samples;

- Dopants vanadium: S93 (wt. $10 \%$ ) sample.

Pure and dopants of the model of the $\mathrm{S} 10$ sample temperature profile:

- Dopants of lanthanum: S28 (wt. $1.0 \%$ ), S38 (wt. $5.0 \%$ ), S40a (wt. $2.0 \%$ ), S48 (wt. $3.0 \%$ ), S52a (wt. $4.0 \%$ ) and S64 (wt. $6.0 \%$ ) samples;

- Dopant of iron: S24 (wt. 2,5\%), S111-S112 (wt. 5.0\%), S117-S118 (wt. $1.0 \%$ ) and S119-S120 (wt. $3.0 \%$ ) samples. The samples of S112, S118 and S120 had a longer calcination duration of $24 \mathrm{~h}$ (calcination duration of $7 \mathrm{~h}$, for S111, S117 and S119 samples);

Pure and dopants of the model of the $\$ 99$ sample temperature profile:

- Dopants vanadium: S93 (wt. $10 \%$ ) sample;

Pure and dopants of the model of the $\$ 102$ sample temperature profile:

- Dopant of vanadium: S96 (wt. 10\%) sample. 


\section{The results of $X R D$ and $X R P D$ diffractions}

The XRPD and XRD patterns of pure and some La-doped $\mathrm{TiO}_{2}$ nanopowders are shown from Figure 2 to Figure 4. The most intensive diffraction picks can be ascribed to the anatase crystal structure (JCPDS card 78-2486). Structure refinements have been performed by the Rietveld method: the lattice parameters, the unit cell volume, the average crystallite size and the average strain in the anatase and brookite phase, and the results of the quantitative phase analysis for brookite (brookite content) are summarized in Table 3 , as partially reported earlier by (Golubović et al, 2009a), (Golubović et al, 2013), (Grujić-Brojčin et al, 2014) and (Šćepanović et al, 2010). The value of the anatase a parameter for the chosen tested samples considered and compared in Table 3 varies around its reference value $\left(a_{0}=0.378479(3) \mathrm{nm}\right)$, whereas the value of the $c$ parameter is slightly lower than the reference one $\left(\mathrm{c}_{0}=0.951237(1) \mathrm{nm}\right.$ ), as reported by Grujic-Brojcin (Grujić-Brojčin et al, 2014) earlier; except for the sample labeled as S96. The unit cell volume of all samples of La-doped $\mathrm{TiO}_{2}$ is also lower in comparison with the reference value, except for the pure $\mathrm{TiO}_{2}$. The structural refinement has revealed that the anatase crystallite size of the doped samples is decreased from 15.0 to $17.5 \mathrm{~nm}$ in the pure $\mathrm{TiO}_{2}$ (S06, S05 and $\mathrm{S} 11$, respectively) to $12 \mathrm{~nm}$ in the La-doped samples. The pure $\mathrm{TiO}_{2^{-}}$ nanoparticles strain is slightly increased with doping (Table 3 ). The brookite phase is highly disordered in all samples, which is indicated with a large value of the average strain in brookite crystallite.

The chosen XRD diffract grams of the chosen pure $\mathrm{TiO}_{2}$ nanoparticles patterns labeled as S07, S08 and S10 are presented in Figure 2, which has been reported earlier by Golubovic et al (Golubović et al, 2009a).

The XPRD patterns labeled as S28, S52a and S64 of anatase $\mathrm{TiO}_{2^{-}}$ NPs doped with different wt. concentration of lanthanum (1 wt. \%, 4 wt. $\%$ and 6 wt. \%, respectively) are presented from Figure 3 to Figure 5, respectively. Figure 4 has been reported earlier by Golubovic et al (Golubović et al, 2009b) as a conference poster. 
Table 3 - The results of the Rietveld analyses of the samples (the unit cell parameters and the unit volume of anatase, the average crystallite size and the average strain in the anatase and brookite mineral forms and the content of brookite form) for pure and La and

$\mathrm{Fe}$-doped $\mathrm{TiO}_{2}-\mathrm{NPs}$ (the values in the paretheses represent the estimated standard deviations) (Golubović et al, 2009a), (Golubović et al, 2013), (Šćepanović et al, 2010), (Grujić-Brojčin et al, 2014)

Таблица 3 - Результаты проведенного по методу Ритвельда анализа образцов (параметры элементарной ячейки анатаза, в том числе ее объема, средний размер кристаллитов и средняя твердость анатаза и брукита и состав фрорм брукита) чистых и La u Fe легированных $\mathrm{TuO}_{2}-\mathrm{H} 4$-е (значения в скобках представляют допустимые отклонения) (Golubović et al, 2009a), (Golubović et al, 2013), (Šćepanović et al, 2010), (Grujić-Brojčin et al, 2014)

Табела 3 - Резултати Ритвалдове анализе узорака (параметри јединичне ћелије и јединичне зепремине анатаса, просечна величина кристалита и просечна сила у минералној форми анатаса и брукита и садржај брукитне форме) за чисте и La u

$\mathrm{Fe}$ допиране $\mathrm{TuO}_{2}-\mathrm{HЧ}$-е (вредности у заградама представљају процењена стандардна одступања) (Golubović et al, 2009a), (Golubović et al, 2013), (Šćepanović et al, 2010), (Grujić-Brojčin et al, 2014)

\begin{tabular}{|c|c|c|c|c|c|c|c|c|c|}
\hline \multirow[b]{2}{*}{$\begin{array}{l}\text { Sam- } \\
\text { ple }\end{array}$} & \multirow[b]{2}{*}{$\begin{array}{l}\text { Dopant } \\
\text { wt. \% }\end{array}$} & \multicolumn{5}{|l|}{ Anatase } & \multicolumn{3}{|l|}{ Brookite } \\
\hline & & $\mathrm{a}(\mathrm{nm})$ & $\mathrm{c}(\mathrm{nm})$ & $\begin{array}{l}V \\
\left(10^{-3} \mathrm{~nm}^{3}\right)\end{array}$ & $\begin{array}{l}\text { Cryst } \\
\text {.size } \\
(\mathrm{nm})\end{array}$ & $\begin{array}{l}\text { Strain } \\
\left(\times 10^{-3}\right)\end{array}$ & $\begin{array}{l}\text { Content } \\
\text { (\%) }\end{array}$ & $\begin{array}{l}\text { Cryst. } \\
\text { size } \\
(\mathrm{nm})\end{array}$ & $\begin{array}{l}\text { Strain } \\
\left(\times 10^{-3}\right)\end{array}$ \\
\hline S05 & 0.0 & $0.37873(0)$ & $0.9496(4)$ & $136.21(4)$ & 15.4 & & & & \\
\hline S06 & 0.0 & $0.37852(0)$ & $0.9484(1)$ & & 17.5 & & & & \\
\hline S07 & 0.0 & $0.37844(1)$ & $0.94838(4)$ & & 12 & 4.5 & 17 & 12 & 16.9 \\
\hline S08 & 0.0 & $0.37856(1)$ & $0.94860(4)$ & & 12 & 4.2 & 16 & 35 & 19.6 \\
\hline S10 & 0.0 & $0.37884(1)$ & $0.94980(3)$ & & 10 & 3.4 & 10 & 58 & 16.8 \\
\hline S11 & 0.0 & $0.37884(1)$ & $0.94980(5)$ & 136.31(1) & 15 & 3 & $10(2)$ & 58 & 17 \\
\hline $\mathrm{S} 18$ & 0.65 & $0.37895(2)$ & $0.9485(1)$ & $136.21(2)$ & 12 & 4 & $42(5)$ & 2 & 29 \\
\hline S28 & 1.0 & $0.37880(2)$ & $0.94780(1)$ & $136.01(2)$ & 10 & 5 & $24(3)$ & 26 & 22 \\
\hline S40a & 2.0 & $0.37853(2)$ & $0.94908(9)$ & $135.99(2)$ & 12 & 8 & $21(1)$ & 12 & 8 \\
\hline S48 & 3.0 & $0.37823(6)$ & $0.9471(3)$ & $135.49(5)$ & 12 & 8 & $21(4)$ & 12 & 8 \\
\hline S16 & 5.0 & $0.37874(3)$ & $0.9485(1)$ & $136.06(2)$ & 12 & 8 & $22(2)$ & 12 & 8 \\
\hline S96 & 10.0 & 0.37719 & 0.95266 & & & & & & \\
\hline
\end{tabular}




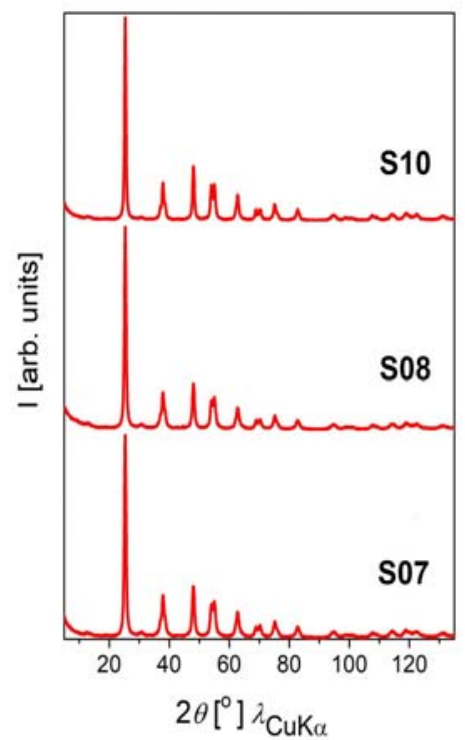

Figure 2 - XRD diffract grams of the chosen temperature profiles of $\mathrm{TiO}_{2}$ samples (Golubović et al, 2009a)

Puc. 2 - XRD-дифррактограммы, выбранных температурных профилей образцов TiO2 (Golubović et al, 2009a)

Слика 2 - XRD дифррактограми одабраних температурних профила $\mathrm{TuO}_{2}$ узорака (Golubović et al, 2009a)

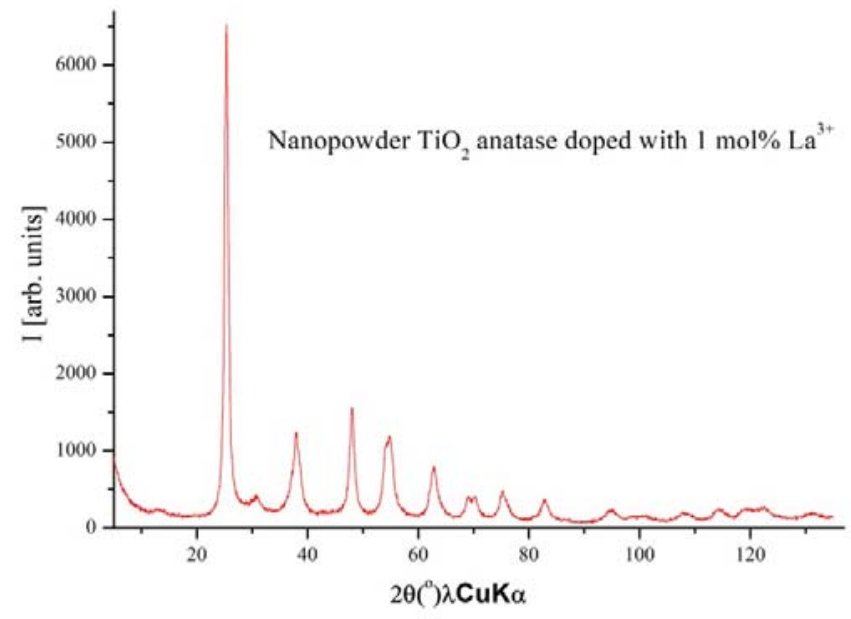

Figure $3-X P R D$ diffract gram for $S 28$ sample Puc. 3 - XPRD-дифррактограмма образца C28 Слика 3 - XPRD дифрактограм за узорак C28 


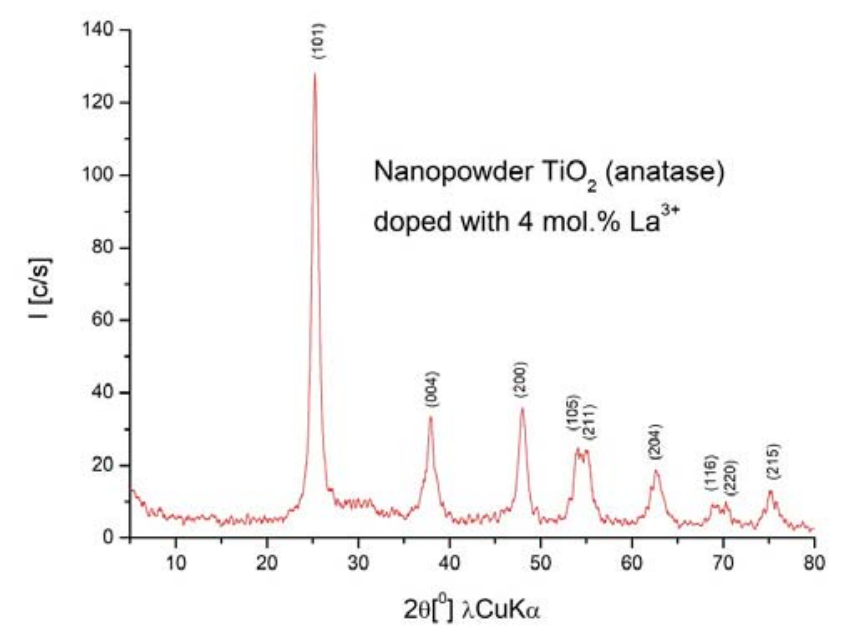

Figure 4 - XPRD diffract gram for S52a sample (Golubović et al, 2009b) Puc. 4 - XPRD-дuфррактограмма образца C52a (Golubović et al, 2009b) Слика 4 - XPRD дифрактограм за узорак C52a (Golubović et al, 2009b)

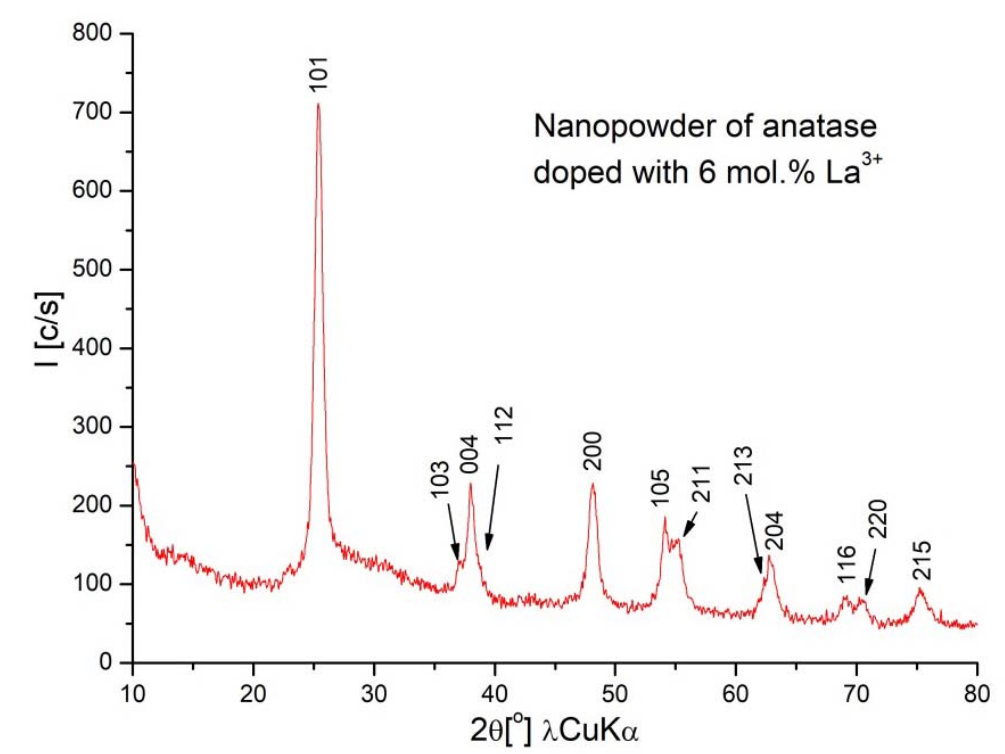

Figure 5 - XPRD diffract gram for 564 sample Puc. 5 - XPRD-дифрактограмма образца C64 Слика 5 - XPRD дифрактограм за узорак C64 
The results of the Raman spectroscopy

In the Raman mode of synthesized pure La and V-doped $\mathrm{TiO}_{2}-\mathrm{NPs}$, which are the subject of this paper, the anatase Raman mode dominates (Ohsaka et al, 1978), (Šćepanović etal, 2007): $\mathrm{Eg}_{(1)}\left(\sim 143 \mathrm{~cm}^{-1}\right), \mathrm{Eg}_{(2}$ ) $\left(\sim 198 \mathrm{~cm}^{-1}\right), \mathrm{B}_{1 \mathrm{~g}}\left(\sim 398 \mathrm{~cm}^{-1}\right), \mathrm{A}_{1 \mathrm{~g}}+\mathrm{B}_{1 \mathrm{~g}}\left(\sim 518 \mathrm{~cm}^{-1}\right)$, and $\mathrm{Eg}_{(3)}\left(\sim 639 \mathrm{~cm}^{-1}\right)$, as reported by Golubovic et al (Golubović et al, 2009a), (Golubović et al, 2013), Grujic-Brojcin et al (Grujić-Brojčinetal, 2014) and Scepanovic et al (Šćepanović etal, 2010). The Raman spectra of the chosen pure and some $\mathrm{La}^{3+}$ and $\mathrm{V}^{3+}$ doped $\mathrm{TiO}_{2}$ nanoparticles were measured at room temperature. Some of these spectra are shown in Figure 6 and Figure 7, as the samples labeled as $\mathrm{S} 11$ (pure $\mathrm{TiO}_{2}-\mathrm{NP}$ ) and $\mathrm{S} 48$ (3 wt. \%):

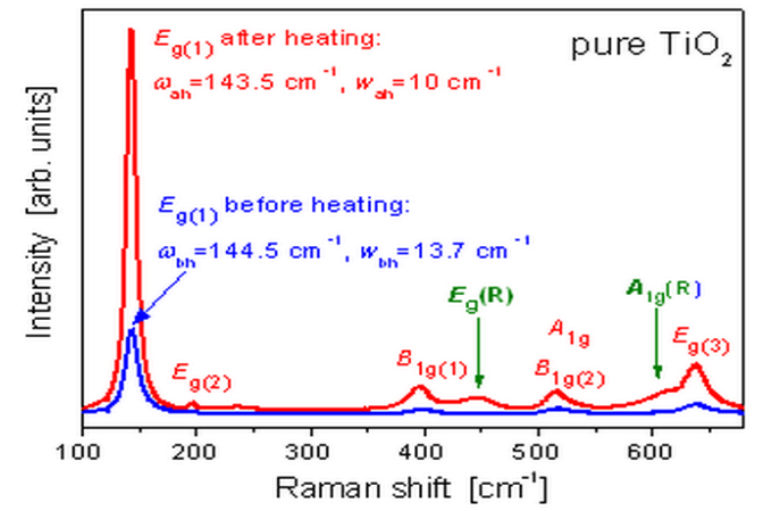

Figure 6 - Raman scattering spectra for S11 sample (Golubović et al, 2009b) Puc. 6 - Рамановская спектроскопия образца C11 (Golubović et al, 2009b) Слика 6 - Раманов расејани спектри за узорак C11 (Golubović et al, 2009b)

On the poster at the conference presented earlier in Figures 6 and 7, Golubovic et al (Golubovic, A. et al. 2009b) reported that the heating of pure $\mathrm{TiO}_{2}$-nanoparticles ( $\mathrm{S} 11$ sample) to $800^{\circ} \mathrm{C}$ causes redshift and narrowing of anatase $\mathrm{E}_{\mathrm{g}(1)}$. The Raman mode as well as the appearance of new Raman modes were assigned to the rutile phase. After the same heating treatment, there are neither a drastic change of $E_{g(1)}$ Raman mode in the spectra of La-doped sample labeled as S48 nor the appearance of additional modes. Therefore, it can be concluded that doping with $\mathrm{La}^{3+}$ ions stabilizes the $\mathrm{TiO}_{2}$ nanostructure in the anatase phase at high temperature. The frequencies of the anatase modes in Vdoped $\mathrm{TiO}_{2}$-nanoparticles shift more with different synthesis conditions, in comparison to their counterparts, as it can been seen from the data listed in Table 4, reported earlier (Šćepanović et al, 2010). 


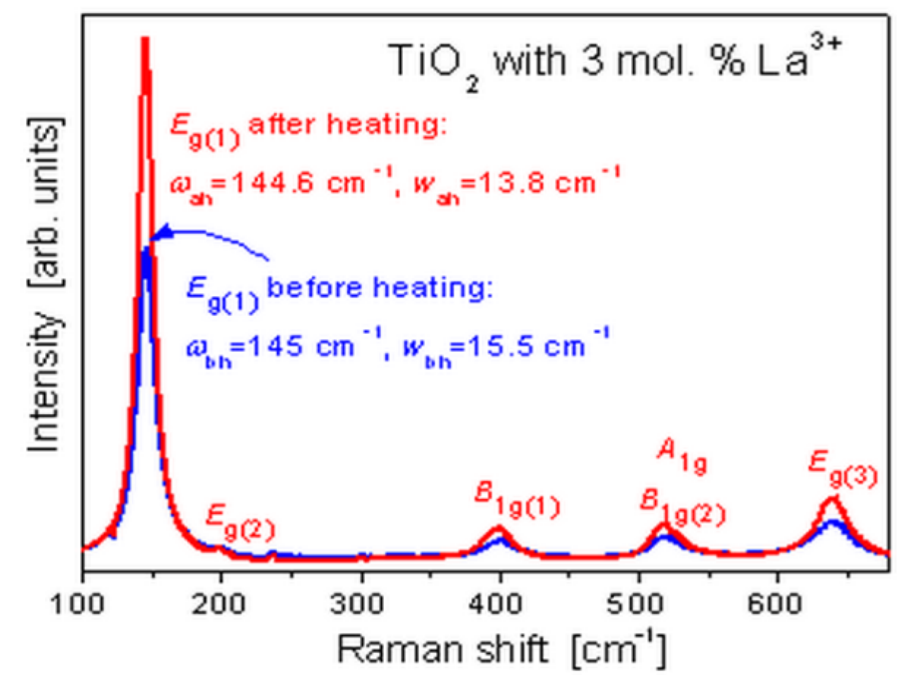

Figure 7 - Raman scattering spectra for S48 sample (Golubović et al, 2009b)

Puc. 7 - Рамановская спектроскопия образца C48 (Golubović et al, 2009b)

Слика 7 - Раманови расејани спектри за узорак C48 (Golubović et al, 2009b)

Table 4 - Frequencies of the anatase Raman modes in the pure and V-doped $\mathrm{TiO}_{2}$ nanoparticle samples

Таблица 4 - Частота Рамановского режима для атаназа чистых и Vлегированных образцов наночастиц $\mathrm{TiO}_{2}$

Табела 4 - Фреквенције Раманових режима за анатас у чистим и V-допираним $\mathrm{TuO}_{2}$ наночестицама

\begin{tabular}{|l|l|l|l|l|l|}
\hline \multirow{2}{*}{ Sample } & \multicolumn{6}{|l|}{ Raman frequencies of anatase modes $\left(\mathrm{cm}^{-1}\right)$} \\
\cline { 2 - 6 } & $\mathrm{E}_{\mathrm{g}(1)}$ & $\mathrm{E}_{\mathrm{g}(2)}$ & $\mathrm{B}_{1 \mathrm{~g}(1)}$ & $\mathrm{A}_{1 \mathrm{~g}(1)}+\mathrm{B}_{1 \mathrm{~g}(2)}$ & $\mathrm{E}_{\mathrm{g}(3)}$ \\
\hline S93 & 145.3 & 198.4 & 397.0 & 516.5 & 637.7 \\
\hline S96 & 148.9 & 201.9 & 394.6 & 514.2 & 633.4 \\
\hline S99 & 143.7 & 197.7 & 396.8 & 518.7 & 639.6 \\
\hline S102 & 143.8 & 197.8 & 397.0 & 518.8 & 639.7 \\
\hline
\end{tabular}

The Raman mode of $\mathrm{TiO}_{2}$-nanoparticles for the chosen pure and $\mathrm{V}$ doped samples, labeled as S99, S93 and S96, respectively, feature twelve well-resolved bands at about 101, 143, 284, 305, 406, 478, 531, 699, 810, 926, 996 and $1020 \mathrm{~cm}^{-1}$, as reported by Scepanovic et al (Šćepanović et al, 2010). The frequencies of these additional Raman modes, which can be related to the presence of vanadium, are listed in Table 5. 
Table 5 - Frequencies of the $\mathrm{V}$-related Raman modes in the $\mathrm{V}$-doped anatase $\mathrm{TiO}_{2}-\mathrm{NPS}$ Таблица 5 - Частоты V-связанных в Рамановском режиме в V-легированных фразах анатаза TiO2-N4

Табела 5 - Фреквенције за V-повезане Раманове режиме у V-допираној фрази анатас $\mathrm{TiO}_{2}-\mathrm{H} 4-\mathrm{a}$

\begin{tabular}{|l|l|l|l|l|l|l|l|l|l|l|l|l|}
\hline \multirow{2}{*}{ Sample } & \multicolumn{9}{|c|}{ Raman frequencies $\left(\mathrm{cm}^{-1}\right)$} \\
\cline { 2 - 16 } & 1 & 2 & 3 & 4 & 5 & 6 & 7 & 8 & 9 & 10 & 11 & 12 \\
\hline $\mathrm{V}_{2} \mathrm{O}_{5}$ & 100 & 143 & 283 & 303 & 407 & 477 & 526 & 696 & - & - & 995 & - \\
\hline $\mathrm{S} 93$ & 101 & 143 & 284 & 305 & 406 & 479 & 532 & 700 & 808 & 924 & 996 & 1017 \\
\hline $\mathrm{S} 96$ & - & 143 & 284 & 308 & - & - & - & 699 & 810 & 934 & 996 & 1027 \\
\hline
\end{tabular}

The measured values of the data from Table 4 and Table 5 have been reported earlier by Scepanovic et al (Šćepanović et al, 2010); it has been reported earlier that the presence of the additional Raman mode in the spectra of doped samples unambiguously shows that vanadium ions formed vanadium oxides (mostly $\mathrm{V}_{2} \mathrm{O}_{5}$ ) and some other vanadate structures in V-doped nanopowders. This confirms that a higher concentration of $\mathrm{V}$ in $\mathrm{TiO}_{2}$ tends to stabilize $\mathrm{V}$ in the $5+$ state predominantly, as reported by Bhattacharyya et al (Bhattacharyya et al, 2010). However, the change in pure $\mathrm{TiO}_{2}$-nanoparticles of the Raman modes in those samples reveals that a certain amount of vanadium ions is introduced into the $\mathrm{TiO}_{2}$ crystal lattice, which strongly depends on the conditions of the synthesis, such as the calcination heating rate and its duration.

\section{The Results of the ESM}

For $\mathrm{TiO}_{2}$, La and $\mathrm{Fe}$ dopants nanoparticles, the particle size distributions were obtained by the elastic sphere model (ESM) and presented in Figures 8 and 11, respectively. In Figure 8, we can see that the mean particle size was around $12 \mathrm{~nm}$ for the La-dopant $\mathrm{TiO}_{2}$ nanoparticles samples up to $4 \mathrm{wt}$. \% of lanthanum ions, compared to pure anatase. The value of the mean particle size is increased for a higher lanthanum ion concentration.

The mean particle size was around $15.5 \mathrm{~nm}$ for $\mathrm{S} 111$ sample of $\mathrm{Fe}-$ dopant of $\mathrm{TiO}_{2}$ nanoparticles in a concentration of $5 \mathrm{wt}$. \%, synthetized at the calcination duration of $7 \mathrm{~h}$, as shown in Figure 11, compared to the same concentration of the La-dopant (Figure 8). 


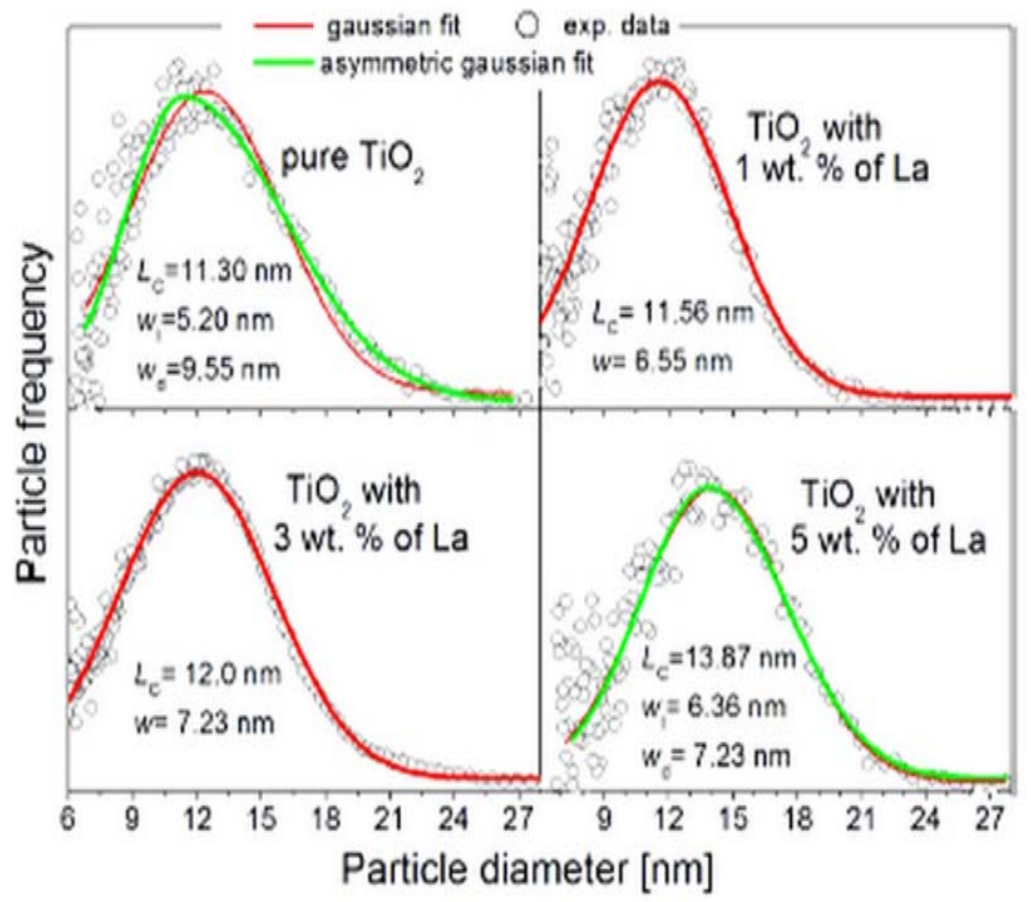

Figure 8 - Particle size distributions in the pure and La-doped $\mathrm{TiO}_{2}$ samples such as $\mathrm{S11}$, S28, S48 and S16 (Golubović et al, 2009b)

Puc. 8 - Распределение частии по размерам в чистых и легированных La образцах TiO2, таких как C11, C28, C48 и C16 (Golubović et al, 2009b)

Слика 8 - Дистрибуција величине честица у чистим и La-допираним TuO 2 узорцима, као C11, C28, C48 и C16 (Golubović et al, 2009b)

The results of the Atomic Force Microscopy Measurements

The surface of the lanthanum and iron doped $\mathrm{TiO}_{2}$ nanoparticles sample labeled as $\mathrm{S} 18$ (0.65 wt. \%) and S111 (5.0 wt. \%) recorded by the AFM in the non-contact mode is shown in Figures 9 (Golubović et al, $2009 \mathrm{~b}), 10$ and 12, respectively. These images are recorded on doped $\mathrm{La}$ and $\mathrm{Fe}$-doped $\mathrm{TiO}_{2}$-nanoparticles, previously dispersed in ethanol, deposited on freshly cleaved highly oriented prolific graphite (HOPG). From these images, we can observe that sample S18 consists of very small nanocrystals of $12 \mathrm{~nm}$ and greater agglomerated particles. Also, sample S111 consists of several larger nanocrystals, with a large number of agglomerates arranged as it can be seen on its particle histogram in Figure 11. 


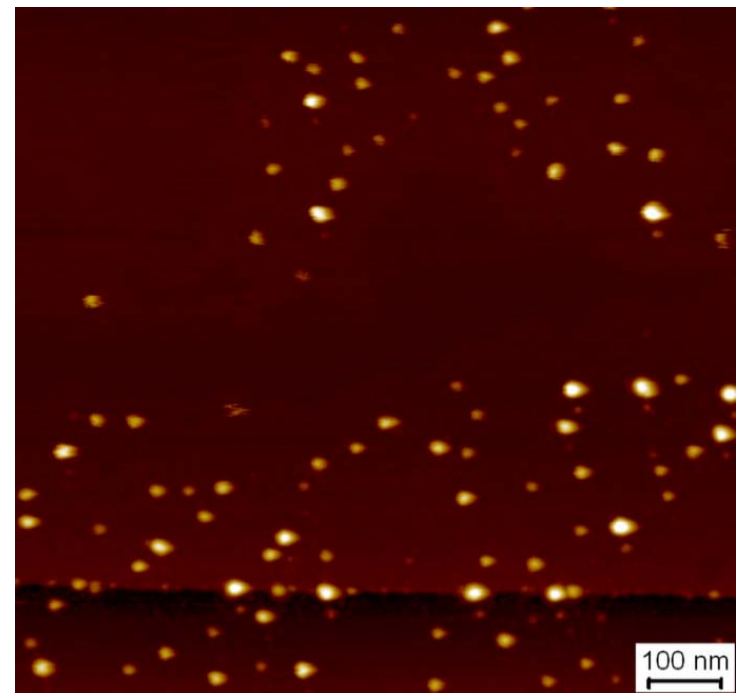

Figure 9 - AFM image of S18 sample (anatase doped with 0.65 wt. \% La ${ }^{3+}$ ) $(1000 \times 1000 \mathrm{~nm})$

Puc. 9 - AFM изображение C18 образца (анатаз легированный с 0.65 вес. \% $\mathrm{La}^{3+}$ ) $(1000 \times 1000 \mathrm{~nm})$

Слика 9 - AFM слика C18 узорка (анатас допиран са 0.65 теж.\% La ${ }^{3+}$ ) $(1000 \times 1000 \mathrm{~nm})$

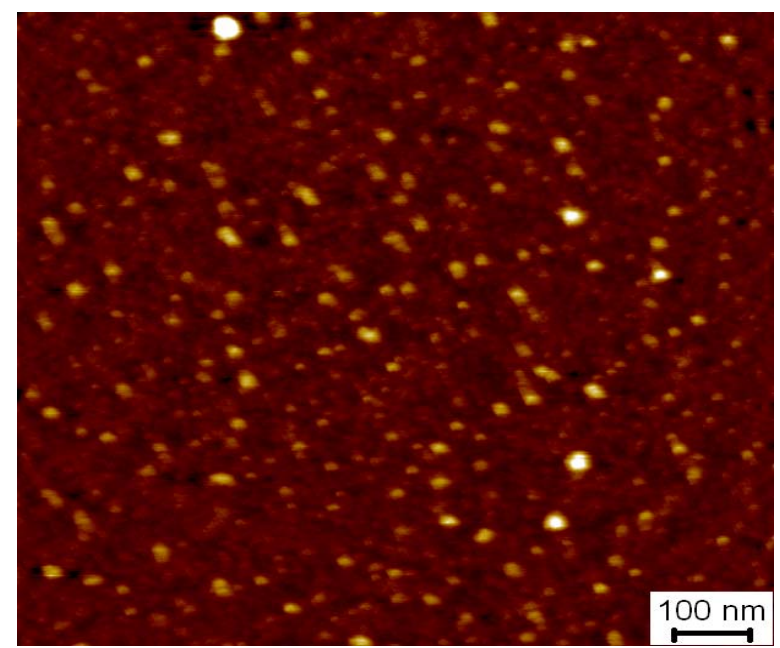

Figure 10 - AFM image of an S111 anatase nanoparticle sample doped with $5 \mathrm{wt} . \% \mathrm{Fe}^{3+}$ and a calcination duration of $7 \mathrm{~h}(1000 \times 1000 \mathrm{~nm})$

Puc. 10 - AFM изображение C111 образца наночастиц атаназа легированных с 5 вес. \% Fe ${ }^{3+}$ и временем прокаливания - 7 ч. (1000 x 1000 nm)

Слика 10 - AFM слика C111 узорка анатас наночестице допиране са

5 теж. \% Fe ${ }^{3+}$ и време трајања калцинације од 7 ч (1000 x $\left.1000 \mathrm{~nm}\right)$ 


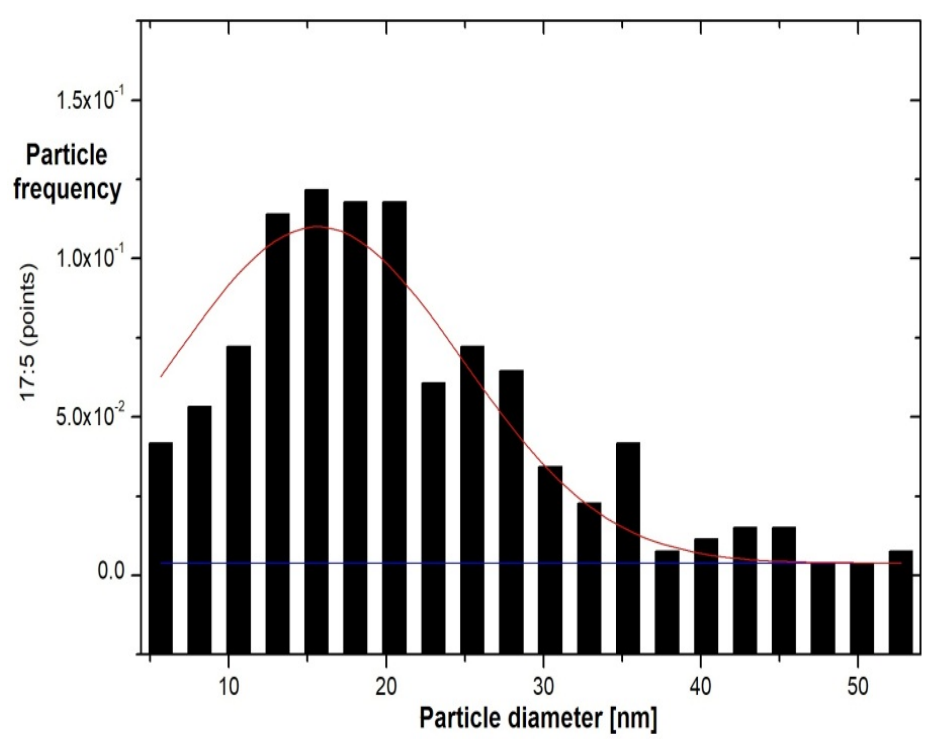

Figure 11 - Particle histogram for the Fe-doped $\mathrm{TiO}_{2}-\mathrm{NP}$ of $\mathrm{S} 111$ sample Puc. 11 - Гистограмма частиц образца C111 (Fe-допант $\mathrm{TiO}_{2}-\mathrm{H} 4$ ) Слика 11 - Хистограм честица за узорак C111 (Fe-допанm $\mathrm{TuO}_{2}-\mathrm{H} 4$-a)

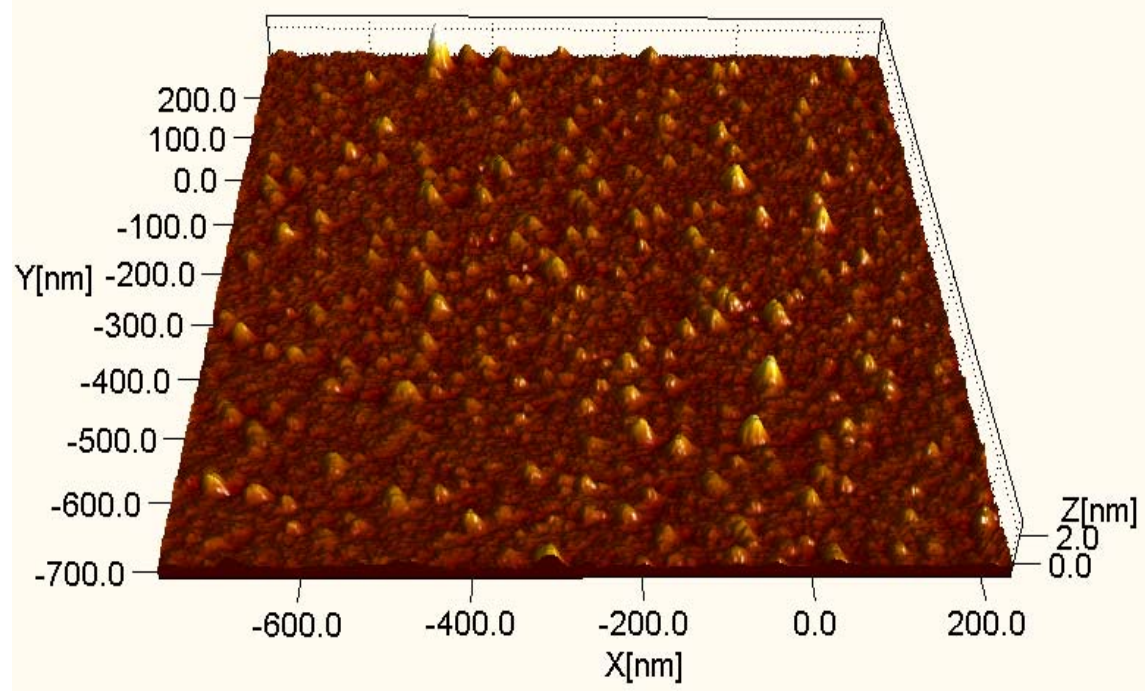

Figure 12 - AFM image of S111 sample - display at an angle Puc. 12 - AFM изображение образца C111 - вид под наклоном Слика 12 - AFM слика узорка C111 - приказ под углом 


\section{Results of the EDS}

The chemical compositions of pure and some chosen La-doped $\mathrm{TiO}_{2}$-nanoparticles have been estimated by the EDS method, and summarized in Table 6, which was partially reported earlier (Golubović et al, 2013), (Grujić-Brojčin et al, 2014).

Table 6 - EDS results for pure and some chosen La-doped $\mathrm{TiO}_{2}-\mathrm{NPS}$ Таблица 6 - EDS результаты по чистым и некоторым La легированным $\mathrm{TiO}_{2}-\mathrm{H} 4$ Табела 6 - EDS резултати за чисте и неке изабране La допиране $\mathrm{TiO}_{2}-\mathrm{H}$-а

\begin{tabular}{|l|l|l|l|l|l|l|l|}
\hline & \multirow{2}{*}{$\begin{array}{l}\text { La } \\
(\text { wt. \%) }\end{array}$} & \begin{tabular}{l} 
EDS data \\
\cline { 3 - 8 } \\
\end{tabular} & $\begin{array}{l}\text { (wt. \%) } \\
\text { (wt. \%) }\end{array}$ & $\begin{array}{l}\text { Na } \\
(\text { wt.\%) }\end{array}$ & $\begin{array}{l}\text { Cl } \\
\text { (wt.\%) }\end{array}$ & $\begin{array}{l}\text { La } \\
\text { (wt.\%) }\end{array}$ & $\begin{array}{l}\text { Total } \\
\text { (wt. \%) }\end{array}$ \\
\hline S06 & 0.0 & 32.72 & 64.54 & 1.84 & 0.90 & 0.0 & 100 \\
\hline S11 & 0.0 & 39.46 & 60.54 & - & - & 0.0 & 100 \\
\hline S18 & 0.65 & 42.91 & 57.09 & - & - & 0.0 & 100 \\
\hline S28 & 1.0 & 49.71 & 49.44 & - & - & 0.85 & 100 \\
\hline S40a & 2.0 & 44.59 & 53.45 & - & - & 1.96 & 100 \\
\hline S64 & 6.0 & 41.71 & 52.39 & - & - & 5.91 & 100 \\
\hline
\end{tabular}

The EDS data (shown in Table 6) and the spectra of pure and Ladoped of $\mathrm{TiO}_{2}$-nanoparticles patterns of samples have been reported earlier by Golubovic et al. (Golubović et al, 2013), for S06 sample and Grujic-Brojcin et al (Grujić-Brojčin et al, 2014), for S11, S18, S28, S40a and S64 samples). These analyzes have shown that only S06 sample synthesized with a calcination duration of $7 \mathrm{~h}$ consists of sodium $\left(\mathrm{Na}^{+}\right)$ and chlorine $\left(\mathrm{Cl}^{-}\right)$ions, which has not been detected in the other observed samples, as we can see in Table 6. Golubovic et al (Golubović et al, 2013) have reported earlier that short duration of calcination may also be the reason for a relatively high concentration of sodium $\left(\mathrm{Na}^{+}\right)$and chlorine $\left(\mathrm{Cl}^{-}\right)$ions in the sample with a calcination duration of $1 \mathrm{~h}$. We can see, in Table 6, that the oxygen weight percent in the pure $\mathrm{TiO}_{2-}$ nanoparticle sample is close to stoichiometric $\mathrm{TiO}_{2}(40.0 \mathrm{wt}$. \%), and that the percent of oxygen is higher in the La-doped samples. Based on the data obtained from the EDS measurement method, the final molar La/Ti ratio is lower than at the beginning of the synthesis process; which is estimated at around $63 \%$ of the starting value, except in the case of the sample doped with $0.65 \mathrm{wt}$. \% of La. Finally, the results also show that a low content of La $(0.65$ wt. \%) could not be detected in S18 sample by the EDS method. 


\section{Results of the BET}

The porous properties of the $\mathrm{TiO}_{2}$-nanoparticles samples such as $\mathrm{P}$ $25, S 05, S 06, S 11, S 18, S 28$ and S40a have been estimated by the BET, BJH and CPMS methods and summarized in Table 7 which has been partially reported earlier (Golubović et al, 2013), (Grujić-Brojčin et al, 2014).

Table 7 - Porous properties of the chosen $\mathrm{TiO}_{2}$ samples (P-25, S05, S06, S11, S18, S28 \& S40a): specific surface area $\left(S_{B E T}, S_{\text {meso }}, S_{\text {mic }} \& S_{B J H}\right)$, pore volume $\left(V_{p} \& V_{\text {mic }}\right)$, mean pore diameters obtained from different methods $\left(\check{D}_{B E T}, \check{D}_{B J H} \& \bar{D}_{C P S M}\right), C P M S$ fitting parameter $\left(N_{s}\right)$ and the predicted tortuosity factor $(\tau)$

Таблица 7 - Характеристики пористой структуры, выбранных образцов $\mathrm{TiO}_{2}(P$ 25, S05, S06, S11, S18, S28 и S40a): Удельная поверхность $\left(S_{B E T}, S_{\text {meso }}, S_{\text {mic }} \& S_{B J H}\right)$, объем пор $\left(V_{p} u V_{\text {mic }}\right)$ различные методы ( $\check{D}_{B E T}$, $\left.\check{D}_{B J H} \& \check{D}_{C P S M}\right)$, CPMS параметры настройки $\left(N_{s}\right)$ и коэфрфиицент извилистости $(\tau)$

Табела 7 - Порозна својства одабраних узорака $\mathrm{TiO}_{2}(P-25, \mathrm{~S} 05, \mathrm{~S} 06, \mathrm{~S} 11, \mathrm{~S} 18, \mathrm{~S} 28$ u S40a): специфична површина $\left(S_{B E T}, S_{\text {meso }}, S_{\text {mic }} \& S_{B J H}\right)$, запремина пора $\left(V_{p} u V_{\text {mic }}\right)$ Средњи пречници пора добијени различитим методама ( $\left.\check{D}_{B E T}, \check{D}_{B J H} \& \check{D}_{C P S M}\right), C P M S$ параметар за подешавање $\left(N_{s}\right)$ и процењени фактор тортуозности $(\tau)$

\begin{tabular}{|c|c|c|c|c|c|c|c|}
\hline \multirow[b]{2}{*}{ Parameters } & \multicolumn{7}{|c|}{ Sample } \\
\hline & P-25 & $\begin{array}{l}\text { S05 } \\
(0.0)\end{array}$ & $\begin{array}{l}\text { S06 } \\
(0.0)\end{array}$ & $\begin{array}{l}\text { S11 } \\
(0.0)\end{array}$ & $\begin{array}{l}\text { S18 } \\
(0.65)\end{array}$ & $\begin{array}{l}\text { S28 } \\
(1.0)\end{array}$ & $\begin{array}{l}\text { S40a } \\
(2.0)\end{array}$ \\
\hline $\mathrm{S}_{\mathrm{BET}}\left(\mathrm{m}^{2} \mathrm{~g}^{-1}\right)$ & 13 & 17 & 51 & 58 & 79 & 84 & 78 \\
\hline$S_{\text {meso }}\left(m^{2} g^{-1}\right)$ & 13 & 17 & 51 & - & & & \\
\hline$S_{\text {mic }}\left(m^{2} g^{-1}\right)$ & - & - & - & - & & & \\
\hline $\mathrm{S}_{\mathrm{BJH}}\left(\mathrm{m}^{2} \mathrm{~g}^{-1}\right)$ & - & & - & 58.2 & 79.4 & 83.8 & 78.1 \\
\hline$V_{p}\left(\mathrm{~cm}^{3} \mathrm{~g}^{-1}\right)$ & 0.024 & 0.030 & 0.088 & 0.160 & 0.185 & 0.258 & 0.215 \\
\hline$V_{\text {mic }}\left(\mathrm{cm}^{3} \mathrm{~g}^{-1}\right)$ & - & - & - & - & & & \\
\hline $\mathrm{D}_{\mathrm{BET}}(\mathrm{nm})$ & 7.5 & 7.1 & 6.9 & 7.1 & 6.0 & 7.9 & 7.1 \\
\hline $\mathrm{D}_{\text {BJH }}(\mathrm{nm})$ & 7.4 & 6.7 & 6.8 & 7.1 & 6.3 & 7.7 & 7.5 \\
\hline $\mathrm{D}_{\mathrm{CPSM}}(\mathrm{nm})$ & 7.7 & 7.4 & 7.1 & 8.1 & 6.9 & 7.7 & 7.5 \\
\hline $\mathrm{N}_{\mathrm{s}}$ & 5.5 & 8 & 4 & 8 & 13 & 12 & 11 \\
\hline$\tau$ & 3.0 & 4.0 & 2.7 & 4.1 & 5.3 & 4.4 & 4.6 \\
\hline
\end{tabular}

In order to investigate the effect of the chosen $\mathrm{TiO}_{2}$ nanoparticles and their lanthanum doped catalysts on the pore structure and the adsorption ability, the nitrogen sorption isotherm measurements have been carried out. The specific surface area $\left(\mathrm{S}_{\mathrm{BET}}\right)$ and the pore volume $\left(V_{p}\right)$ obtained by the BET method, and the mesopore diameter calculated from both the BET and the BJH ( $D_{B E T}, D_{B J H}$, respectively) for the chosen samples can be seen in Table 7, the data of which have been shown earlier by Golubovic et al (Golubović et al, 2013) for P-25, S05 and S06 
patterns of samples and by Grujic-Brojcin et al (Grujić-Brojčin et al, 2014), for S11, S18, S28 and S40a patterns of samples, respectively.

Based on the porosity parameters obtained from the standard nitrogen adsorption isotherms determined from the $\alpha_{c}$ plot (Kaneko et al, 1998), we can also establish that the chosen $\mathrm{TiO}_{2}$ samples are completely mesoporous nanoparticles. The value of $\mathrm{S}_{\mathrm{BET}}$ in the La-doped samples, S18 and S28: 79 and $84 \mathrm{~m}^{2} \mathrm{~g}^{-1}$, respectively, are higher than those in the pure $\mathrm{TiO}_{2}$ nanoparticles samples, S05, S06 and S11: 17, 51 and $58 \mathrm{~m}^{2} \mathrm{~g}^{-1}$ respectively. Also, the values of $S_{\mathrm{BET}}$ for the synthesis of $\mathrm{TiO}_{2}$ nanoparticles, in the range of $17-58 \mathrm{~m}^{2} \mathrm{~g}^{-1}$ are greater than $\mathrm{S}_{\mathrm{BET}}$ of Degussa $\mathrm{P}-25^{\circledR}$ in the value of $13 \mathrm{~m}^{2} \mathrm{~g}^{-1}$. The mean pore diameters, obtained from the BET results $\left(1 / 4 \mathrm{D}_{\mathrm{BET}} \bullet 4 \mathrm{Vp}=\mathrm{S}_{\mathrm{BET}}\right)$ were in good agreement with the diameters obtained by the BJH method. The most commonly used method entitled as the BJH method for the determination of the pore size distribution (PSD) listed in Table 7, as reported by Barrett (Barrett et al, 1951), is estimated from the desorption branch of the hysteresis isotherm loops. Also, the CPSM method (Salmas \& Androutsopoulos, 2001), (Androutsopoulos \& Salmas, 2000) for the PSD evaluation has been applied. In this method, the pore structure is considered as a statistically large number of independent, nonintersected corrugated pores, made of a series of $\mathrm{N}_{S}$ cylindrical segments of equal length, with randomly distributed diameters of mesopores nanoparticles (Golubović et al, 2013), (Salmas \& Androutsopoulos, 2001), (Androutsopoulos \& Salmas, 2000). The CPSM fitting parameter $\mathrm{N}_{\mathrm{S}}$, mentioned above, is also listed in Table 7: higher values of $\mathrm{N}_{\mathrm{S}}$ have been obtained for the doped samples, which can be associated with a more complex pore structure in the doped samples (Salmas \& Androutsopoulos, 2001). As a result of the CPSM, the pore tortuosity factor $\mathrm{T}$ is also estimated and listed in Table 7, as a measure of diffusion through porous media based on the nitrogen sorption hysteresis data (Golubović et al, 2013), (Salmas \& Androutsopoulos, 2001). The dependence of the tortuosity factor on the La-content in the doped samples shows the same tendency as $N_{S}$ (Grujić-Brojčin et al, 2014); higher values of $\mathrm{T}$ are obtained for the doped samples, with the maximum in S18 sample with $\mathrm{T}=5.3$. This points to the most complex pore structure consisting of interconnected pore segments with different diameters in this sample.

Finally, we expect that the best catalytic properties of the chosen $\mathrm{TiO}_{2}$-NPs samples are found in $\mathrm{S} 11$ as pure and in S28 dopant sample that doped $\mathrm{TiO}_{2}$ nanoparticles in a concentration of 1.0 mole $\%$ of $\mathrm{La}^{3+}$ ions, based on the value of the $S_{B E T}$ in Table 7 . If we compare the 
properties of S05 samples synthesized with the calcination duration of 5 $\mathrm{h}$ and S06 and S11 samples, whose calcination duration was $7 \mathrm{~h}$, we can determine that the catalysts calcined for $7 \mathrm{~h}$ have better properties. The best properties found in $\mathrm{S} 11$ sample for pure $\mathrm{TiO}_{2}$ nanoparticles, as seen in Table 7, led us to choose this pure $\mathrm{TiO}_{2}$ sample for photocatalytic research and testing in our study.

\section{Result of the photocatalytic activities}

The photocatalytic activity was measured in four experiments: three experiments of photocatalytic activities and one coupled photocatalyticmicrobiological experiment. All experiments were carried out in a bath slurry-catalyst circular photoreactor, in dark and under direct ultraviolet radiation simulated with a sodium SONT UV400 lamp, with the initial concentrations of $1.00 \mathrm{ml} / \mathrm{L}$ and $0.50 \mathrm{ml} / \mathrm{L}$ MTBE in the water solution, respectively, depending on the types of experiments.

\section{Results of the experiments of the photocatalytic activities}

The experimental investigation of the photocatalytic degradation of MTBE was performed in three different experiments. The initial concentration in all these experiments was $1.00 \mathrm{ml} / \mathrm{L}$ and the solutions were thermo-stated at $30^{\circ} \mathrm{C}$. All solutions were tested for 60 minutes in the bath slurry-catalyst circular photoreactor in aerobic conditions and their degradation rate was measured in 15-minute intervals.

The first experiment was carried out under direct UV radiation simulated with the sodium SONT UV400 lamp in the photoreactor with the initial concentration of $0.50 \mathrm{ml} / \mathrm{L}$ of the MTBE water solution and different types of synthetized $\mathrm{TiO}_{2}$ nanoparticles, using the following samples of $\mathrm{TiO}_{2}$ nanoparticles: $\mathrm{S} 07$ (pure $\mathrm{TiO}_{2}$ nanoparticles), S18, S28, S38, S40a, S48, S52a and S64 $\left(\mathrm{TiO}_{2}\right.$ nanoparticles doped with $\mathrm{La}^{3+}$ in the following concentration: $0.65 ; 1.0 ; 2.0 ; 3.0 ; 4.0 ; 5.0$ and 6.0 wt. \%, respectively) and one commercial $\mathrm{TiO}_{2}$ nanoparticles catalyst (Degussa $P-25^{\circledR}$ ). The concentration of all catalysts used in the experiment was 0.1 $\mathrm{g} / \mathrm{L}$. The results of the measurements of the detected reduction of the MTBE concentration during all experiments at the GC/MSD/Headspace are shown In Table 8.

Our results in the experiment show that the best photocatalytic efficiency was obtained in $\mathrm{TiO}_{2}$ doped with $\mathrm{La}^{3+}$ of $1 \mathrm{wt}$. \%, but the fastest drop in the polluted MTBE concentration in the water solution was achieved in $\mathrm{TiO}_{2}$ doped with $\mathrm{La}^{3+}$ of 3 wt. \%. 
Table 8 - Photocatalytic degradation of the MTBE initial concentration of $1.00 \mathrm{ml} / \mathrm{L}$ with different concentrations of La-doping of $\mathrm{TiO}_{2}-\mathrm{NPs}$ and pure $\mathrm{TiO}_{2}-\mathrm{NPs}$ (synthetized and commercial Degussa $P-25^{\circledR}$ ) in a concentration of $0.1 \mathrm{~g} / \mathrm{L}$

Таблица 8 - Фотокаталитическая деградация МТБЭ начальной концентрации 1,00 ml/L c различной концентрацией $\mathrm{La}$ - легированных $\mathrm{TiO}_{2}-\mathrm{H} 4$ и чистых $\mathrm{TiO}_{2}-\mathrm{H} 4$ (синтезировано в коммерческих целях Degussa P-25 ${ }^{\circledR}$ ) с концентрацией 0,1 g/L

Табела 8 - Фотокаталитичка деградација МТБЕ почетне концентрације од 1,00 $\mathrm{ml} / \mathrm{L}$ са различитом концентрацијом La -допинта $\mathrm{TiO}_{2}-\mathrm{H} 4$-а и чистux $\mathrm{TiO}_{2}-\mathrm{H} 4$-а (синтетизованог и комерцијалног Degussa P-25 ${ }^{\circledR}$ ) у концентрацији од 0,1 g/L

\begin{tabular}{|l|l|l|l|l|l|l|l|l|l|}
\hline \multirow{2}{*}{$\begin{array}{l}\text { Time } \\
\text { UV } \\
(\mathrm{min})\end{array}$} & \multirow{2}{*}{$\mathrm{S} 07$} & $\mathrm{P}-25$ & \multicolumn{6}{|l|}{ Samples $\mathrm{TiO}_{2}$ doped with different wt. \% $\mathrm{La}^{3+}$} \\
\cline { 4 - 11 } & $\begin{array}{l}\mathrm{S} 18 \\
(0.65)\end{array}$ & $\begin{array}{l}\mathrm{S} 28 \\
(1.0)\end{array}$ & $\begin{array}{l}\mathrm{S} 40 \mathrm{a} \\
(2.0)\end{array}$ & $\begin{array}{l}\mathrm{S} 48 \\
(3.0)\end{array}$ & $\begin{array}{l}\mathrm{S} 52 \mathrm{a} \\
(4.0)\end{array}$ & $\begin{array}{l}\mathrm{S} 38 \\
(5,0)\end{array}$ & $\begin{array}{l}\mathrm{S} 64 \\
(6.0)\end{array}$ \\
\hline 0 & 1.000 & 1.000 & 1.000 & 1.000 & 1.000 & 1.000 & 1.000 & 1.000 & 1.000 \\
\hline 15 & - & - & 0.797 & - & - & 0.184 & 0.678 & & 0.671 \\
\hline 30 & 0.659 & - & 0.188 & 0.180 & 0.198 & - & 0.132 & & 0.410 \\
\hline 45 & & & 0.095 & 0.062 & - & - & & 0.225 & 0.239 \\
\hline 60 & 0.093 & 0.488 & - & - & 0.122 & 0.178 & 0.052 & - & - \\
\hline
\end{tabular}

The second experiment was carried out under direct ultraviolet radiation simulated with the SONT UV400 lamp in the photoreactor with the initial concentration of $1.00 \mathrm{ml} / \mathrm{L}$ of the MTBE water solution in presence of the catalyst synthetized $\mathrm{TiO}_{2}$-nanoparticles doped with different concentrations of $\mathrm{Fe}^{3+}$ ions and their two calcination durations of 7 and $24 \mathrm{~h}$. We tested the photocatalytic activities catalysts and their dependence on the calcination duration of the following samples: S111 S112 (5 wt. \%, calcination duration of 7 and 24h, respectively), S117 S118 (1 wt. \%, calcination duration of 7 and 24h, respectively), and S119 - S120 (3 wt. \%, calcination duration of 7 and $24 \mathrm{~h}$, respectively), as a photocatalytic degradation degree of MTBE in the water solution. The carbon-dioxide evolution during the experiment is shown in Table 9 in comparison with pure $\mathrm{TiO}_{2}$-nanoparticles: synthetized $\mathrm{S} 07$ catalyst sample and commercial catalyst - Degussa $\mathrm{P}-25^{\circledR}$, determined at the GC/MSD/Headspace (as shown In Table 8). The concentration of all catalysts used in the experiment was $0.1 \mathrm{~g} / \mathrm{L}$.

Our results in the second experiment show that the best photocatalytic efficiency was found in $\mathrm{TiO}_{2}$ doped with the highest concentration of $\mathrm{Fe}^{3+}$ ions dopant, 5 wt. $\%$ and the calcination duration time of $7 \mathrm{~h}$. The greatest difference in the degradation degree versus the calcination duration is the highest concentration catalyst, and the smallest concentration is 3 wt. $\%$ of the $\mathrm{Fe}$-doped $\mathrm{TiO}_{2}$ nanoparticle catalyst. 
Table 9 - Photocatalytic degradation of MTBE as the percentage of the total $\mathrm{CO}_{2}$ yield, the initial concentration of $1.00 \mathrm{ml} / \mathrm{L}$ MTBE in the water solution with different concentrations of Fe-doping of $\mathrm{TiO}_{2}-\mathrm{NPs}$ and pure $\mathrm{TiO}_{2}-\mathrm{NPs}$ (synthetized and commercial Degussa $P-25^{\circledR}$ ) in a concentration of $0.1 \mathrm{~g} / \mathrm{L}$

Таблица 9 - Фотокаталитическая деградация МТБЭ как процент общего выброса $\mathrm{CO}_{2}$, с начальной концентрацией 1,00 mI/L MТБЭ в водном растворе с различной концентрацией $\mathrm{Fe}$-легированных $\mathrm{TiO}_{2}-\mathrm{H} 4$ и чистых $\mathrm{TiO}_{2}-\mathrm{H} 4$ (синтезировано в коммерческих целях Degussa P-25 ${ }^{\circledR}$ ) с концентрацией $0,1 \mathrm{~g} / \mathrm{L}$

Табела 9 - Фотокаталитичка деградација МТБЕ-а као проценат укупног приноса $\mathrm{CO}_{2}$, почетне концентрације од 1,00 ml/L MТБЕ у воденом раствору са различитом концентрацијом Fe-допинга од TuO2-H4-а и чистих TuO2-H4-а (синтетизованог и комерцијалног Degussa $P-25^{\circledR}$ ) у концентрацији од 0,1 g/L

\begin{tabular}{|l|l|l|l|l|l|l|l|l|}
\hline \multirow{2}{*}{$\begin{array}{l}\text { Time } \\
\text { UV } \\
(\mathrm{min})\end{array}$} & \multirow{2}{*}{ S07 } & P-25 & & \multicolumn{6}{|l|}{ Samples $\mathrm{TiO}_{2}$ doped with different wt. \% $\mathrm{Fe}^{3+}$} \\
\cline { 4 - 9 } & & $\begin{array}{l}\mathrm{S} 111 \\
(5.0)\end{array}$ & $\begin{array}{l}\mathrm{S} 112 \\
(5.0)\end{array}$ & $\begin{array}{l}\mathrm{S} 117 \\
(1.0)\end{array}$ & $\begin{array}{l}\mathrm{S} 118 \\
(1.0)\end{array}$ & $\begin{array}{l}\mathrm{S} 119 \\
(3.0)\end{array}$ & $\begin{array}{l}\mathrm{S} 120 \\
(3.0)\end{array}$ \\
\hline 0 & 0.000 & 0.000 & 0.000 & 0.000 & 0.000 & 0.000 & 0.000 & 0.000 \\
\hline 15 & - & - & 0.273 & 0.258 & - & 0.180 & 0.323 & - \\
\hline 30 & 0.341 & & 0.550 & 0.486 & 0.442 & 0.402 & - & 0.494 \\
\hline 45 & & & 0.845 & - & 0.765 & 0.702 & 0.827 & 0.664 \\
\hline 60 & 0.907 & 0.512 & 0.976 & 0.931 & 0.905 & 0.899 & 0.928 & 0.922 \\
\hline
\end{tabular}

The third experiment was carried out under direct UV light exposure simulated with the SONT UV400 lamp in the photoreactor with the initial concentration of $1.00 \mathrm{ml} / \mathrm{L}$ of the MTBE water solution in the presence of different catalyst types of synthetized $\mathrm{TiO}_{2}$ nanoparticles, using the following samples of $\mathrm{TiO}_{2}$ nanoparticles: $\mathrm{S} 07$ (pure $\mathrm{TiO}_{2}-\mathrm{NP}$ ), S93 and S96 $\left(\mathrm{TiO}_{2}-\mathrm{NPs}\right.$ doped with 10 wt. \% V $\left.{ }^{3+}\right)$, S28 $\left(\mathrm{TiO}_{2}-\mathrm{NPs}\right.$ doped with 1.0 wt. $\% \mathrm{La}^{3+}$ ), and commercial $\mathrm{TiO}_{2}$ nanoparticles (Degussa $\mathrm{P}-25^{\circledR}$ ). The results of the measurement of the detected reduction of the MTBE concentration during the experiments were determined at the GC/MSD/Headspace. The results of the photocatalytic degradation of MTBE (Table 9) for the samples such as S117, S119 and S111 $\left(\mathrm{TiO}_{2^{-}}\right.$ NPs doped with $1.0,3.0$ and 5.0 wt. $\% \mathrm{Fe}^{3+}$, respectively, with the duration time of $7 \mathrm{~h}$ for all samples) are shown for comparison in Table 10. The concentration of all catalysts used in the experiment was $0.1 \mathrm{~g} / \mathrm{L}$. 
Table 10 - Photocatalytic degradation of the MTBE initial concentration of $1.00 \mathrm{ml} / \mathrm{L}$ with

$\mathrm{La}, \mathrm{Fe}$ and $\mathrm{V}$-doping of $\mathrm{TiO}_{2}-\mathrm{NPs}$ and pure $\mathrm{TiO}_{2}-\mathrm{NPs}$ (synthetized and commercial

Degussa $P-25^{\circledR}$ ) in a concentration of $0.1 \mathrm{~g} / \mathrm{L}$

Таблица 10 - Фотокаталитическая деградация МТБЭ начальной концентрации $1,00 \mathrm{ml} / \mathrm{L}$ c La Fe u V - легированных $\mathrm{TiO}_{2}-\mathrm{H} 4$ и чистых $\mathrm{TiO}_{2}-\mathrm{H} 4$ (синтезировано 8 коммерческих целях Degussa P-25 $5^{\circledR}$ с с концентрацией 0,1 g/L

Табела 10 - Фотокаталитичка деградација МТБЕ-а почетне концентрације од 1,00 ml/L ca La, Fe u V-допингом $\mathrm{TuO}_{2}-\mathrm{H}$-а и чисто $\mathrm{TuO}_{2}-\mathrm{H}$-а (синтетизованог и комерцијалног Degussa P-25 $5^{\circledR}$ у концентрацији од $0,1 \mathrm{~g} / \mathrm{L}$

\begin{tabular}{|l|l|l|l|l|l|l|l|l|}
\hline \multirow{2}{*}{$\begin{array}{l}\text { Time } \\
\text { UV } \\
(\mathrm{min})\end{array}$} & \multirow{2}{*}{$\mathrm{S} 07$} & \multirow{2}{*}{$\mathrm{P}-25$} & \multicolumn{2}{|l|}{$\begin{array}{l}\text { Samples } \mathrm{TiO}_{2} \text { doped } \\
\text { with different } \mathrm{wt}^{3+}\end{array}$} & $\begin{array}{l}\mathrm{La}^{3+}, \mathrm{wt} \\
\%\end{array}$ & \multicolumn{2}{|l|}{$\mathrm{Fe}^{3+}, \mathrm{wt.} \%$} \\
\cline { 4 - 10 } & & & $\begin{array}{l}\mathrm{S} 93 \\
(10.0)\end{array}$ & $\begin{array}{l}\mathrm{S} 96 \\
(10.0)\end{array}$ & $\begin{array}{l}\mathrm{S} 28 \\
(1.0)\end{array}$ & $\begin{array}{l}\mathrm{S} 117 \\
(1.0)\end{array}$ & $\begin{array}{l}\mathrm{S} 119 \\
(3.0)\end{array}$ & $\begin{array}{l}\mathrm{S} 111 \\
(5.0)\end{array}$ \\
\hline 0 & 1.000 & 1.000 & 1.000 & 1.000 & 1.000 & 1.000 & 1.000 & 1.000 \\
\hline 15 & - & - & 0.345 & - & & - & 0.777 & 0.727 \\
\hline 30 & 0.659 & - & - & 0.650 & 0.180 & 0.558 & - & 0.450 \\
\hline 45 & - & - & 0.152 & - & 0.062 & 0.235 & 0.173 & 0.155 \\
\hline 60 & 0.093 & 0.488 & - & - & - & 0.095 & 0.072 & 0.024 \\
\hline
\end{tabular}

Our results in the experiment show that the best photocatalytic efficiency was found in $\mathrm{TiO}_{2}$ doped with $\mathrm{La}^{3+}$ of 1.0 wt. \% (S28 sample) for 45 minutes, but the fastest drop in the polluted MTBE concentration in the water solution was in $\mathrm{TiO}_{2}$ doped with $\mathrm{V}^{3+}$ of $10.0 \mathrm{wt}$. \% (sample S93). Also, our results show different degradation rates for $\mathrm{TiO}_{2}$ doped with $\mathrm{V}^{3+}$ of $10.0 \mathrm{wt}$. \%, S93 and S96 samples, synthetized with different duration times ( 7 and $24 \mathrm{~h}$, respectively). This can be explained by a different nanomaterial structure. If we compare the results in Table 10, we can see that the best degree of the total MTBE degradation in 60 minutes is achieved in S111 and S119 catalysts, which were doped with 3.0 and 5.0 wt. \% of Fe, respectively, but their total MTBE degradation is smaller for 45 minutes compared to the case when we used the Ladopant of $\mathrm{TiO}_{2}$-NPs as a catalyst ( $\mathrm{S} 28$ sample).

Results of the coupled photocatalytic-microbiological experiment

The experimental investigation of the coupled photocatalyticmicrobiological degradation of MTBE was performed in one experiment. The initial concentration in the experiment was $0.50 \mathrm{ml} / \mathrm{L}$, and the solutions were thermo-stated at $30^{\circ} \mathrm{C}$.

The experiment was carried out under direct ultraviolet light exposure simulated with the UV lamp in the batch slurry-catalyst circular photoreactor in the presence of the microorganism (MO) Pseudomonas aeruginosa strain ATCC 9023 with the initial concentration of $10^{7}$ CFU 
$\mathrm{mL}^{-1}$ (as explained in the following experimental part: Microbial activity and inactivity of the coupled photocatalytic-microbiological experiment) and with different concentrations $(0.25,0.50,0.75$ and $1.0 \mathrm{~g} / \mathrm{L})$ of commercial $\mathrm{TiO}_{2}$ nanoparticles - Degussa P-25 (Degussa P-25 ${ }^{\circledR}$, AG Frankfurt), and without a catalyst. The results of this research are shown in Table 11. All solutions were tested for 150 minutes in the photoreactor and gas chromatography with a mass detector using the headspace (GC/MSD/Headspace) has been applied in 15-minute intervals, and we presented only three time intervals (0,60 and 150 minutes).

Table 11 - Photocatalytic activity of the coupled photocatalytic-microbiological processes in the first experiment

Таблица 11 - Фотокаталитическая активность комбинационного фотокаталично-микробиологического прочесса первого эксперимента Табела 11 - Фотокаталитичка активност комбинованих фотокаталитичкомикробиолошких процеса у првом експерименту

\begin{tabular}{|l|l|l|l|l|l|l|l|}
\hline $\begin{array}{l}\text { Serial } \\
\text { No. }\end{array}$ & $\begin{array}{l}\text { Time } \\
(\mathrm{min})\end{array}$ & I sol. (\% ) & II sol. (\%) & III sol. (\% ) & IV sol. (\% ) & V sol. (\% ) & VI sol. (\% ) \\
\hline 1 & 0.00 & 1.000 & 1.000 & 1.000 & 1.000 & 1.000 & 1.000 \\
\hline 2 & 60.0 & 0.371 & 0.308 & 0.512 & 0.664 & 0.325 & 0.172 \\
\hline 3 & 150.0 & 0.144 & 0.144 & 0.199 & 0.344 & 0.119 & 0.030 \\
\hline \multicolumn{10}{|l|}{} \\
\hline
\end{tabular}

The results in Table 11 show that the best degradation degree of MTBE was obtained in the $\mathrm{VI}$ solution, when we used direct UV radiation simulated with the sodium lamp - SONT UV400 and $0.75 \mathrm{~g} / \mathrm{L}$ of $\mathrm{TiO}_{2}$ powder Degussa P-25 ${ }^{\circledR}$ for 60 and 150 minutes. The results of the I and II solutions show that the $\mathrm{TiO}_{2}$ catalyst in a concentration of $1.0 \mathrm{~g} / \mathrm{L}$ achieved the detoxification effect on the $\mathrm{MO}$ after 60 minutes of the coupled process of the MTBE degradation; a better result was also achieved when we used the lamp and $\mathrm{TiO}_{2}$ powder Degussa $\mathrm{P}-25^{\circledR}$ in the concentration of $0.25 \mathrm{~g} / \mathrm{L}$. Also, the IV solution presented that the dark experiment (without the UV lamp and the catalyst) resulted in a higher MTBE degradation degree than in the I, II and IV solutions, especially in the highest concentration as well as in the effect of aeration condition in all experiments. These results show that $\mathrm{TiO}_{2}$ and direct ultraviolet radiation simulated with the sodium lamp - SONT UV400 inactivate and kill microorganisms. The optical density results have proven this assertion by measuring the microbial activity and inactivity in the coupled 
photocatalytic-microbiological experiment, which is shown in the text bellow.

\section{Results of the microbiological growth}

The measurements of the microbiological growth for the selected Pseudomonas aeruginosa strains (ATCC 9023 and DV 2739) were studied in three experiments, one as the microbial activity and inactivity in the coupled photocatalytic-microbiological experiment and two in the experiments on antimicrobial activities. The coupled photocatalyticmicrobiological experiment was performed in the batch slurry-catalyst circular photoreactor, in dark and under direct ultraviolet radiation simulated with the SONT UV400 lamp. The experiments on antimicrobial activities were carried out in the microbiological cabinet. The text below gives the optical density values, measured during these experiments.

Results of the microbial activity and inactivity of the coupled photocatalytic-microbiological experiment

The microbial activity and inactivity of the coupled photocatalyticmicrobiological experiment are determined by the optical density measurement for the MTBE solutions in the colorimeter, at $550 \mathrm{~nm}$. The results are shown in Table 12.

Our results show the following characteristics of the coupled photocatalytic-microbiological experiment:

- I solution: This experimental result shows that there has been a linear increase in the growth of microorganisms, with the reduction of concentration of MTBE in the water solution at 90 and 150 minutes. The reduction of the concentration of MTBE is actually achieved owing to the combined influence of UV radiation simulated by the sodium lamp and the $\mathrm{MO}$ in aerobic conditions, which is shown in the coupled photo catalyticmicrobiological degradation of MTBE (Tab. 11) and the MO activity (Tab. 12);

- II solution: The experiment with direct ultraviolet radiation simulated with the sodium lamp and the $\mathrm{TiO}_{2}$ catalyst at a concentration of $1.0 \mathrm{~g} / \mathrm{L}$ in the presence of $\mathrm{MO}$ showed an increase in the $\mathrm{MO}$ growth (30.0 min.); constant values (30.0 to 45.0) and low (45.0 to 75.0), after which a low drop in the MO growth occurred. Also, a somewhat greater decrease in the MTBE concentration was achieved than in the I solution at the end of the experiment $(t=150 \mathrm{~min})$; the MTBE degradation 
degree was identical in both experiments (Tab. 11); also, a slightly lower MTBE concentration was achieved, as in accordance with the I solution, but at the end of the experiment $(\mathrm{t}$ $=150 \mathrm{~min}$ ), the identical MTBE degradation rates in both experiments are achieved, as shown in Table 11;

- III solution: Our result in the dark condition experiment showed that there has been a decrease in the MO growth to 135.0 minute, after which the $\mathrm{MO}$ growth increased. The effect in the last 15-20 minutes is possible to be explained by the aerobic conditions which caused the degradation degree of MTBE in the water solution at the end of the experiment.

- IV and V solution: The results of both experiments showed a very similar profile of the catalyst influence (inactivity of activity) with direct artificial irradiation of the lamp on the MO in the aerobic conditions, and a reduced $\mathrm{MO}$ growth at the end of both experiments. A high degradation degree of MTBE in the water solution was obtained in the $\mathrm{V}$ solution compared to the IV solution due to a greater $M O$ number and the catalyst concentration, as shown in Tables 11 and 12, respectively.

- VI solution: Our experiment results showed that there was an increase in the MO growth at the 30th minute, followed by the MO growth reduction until the end of the experiment. This phenomenon can be explained in the following way: in the first 15 minutes, a high concentration of the catalyst inactivated the $\mathrm{MO}$; after that, the $\mathrm{MO}$ accommodated to this condition and grew in the next 15 minutes due to the feeding with MTBE in aeration conditions. At the moment of a large decomposition of MTBE, which is formed in the coupled process, the detoxification of the microorganisms occurs.

By comparing the results of the I to VI solution experiments, we have found out that the best results are achieved in the VI solution experiment due to the excessive concentration of the catalyst, which has a large inactivating effect on the MO. It has negatively affected the coupled photocatalytic-microbiological processes. Therefore, the best property of the coupled photocatalytic-microbiological experiment is achieved with the initial concentration of $0.75 \mathrm{~g} / \mathrm{L}$ Degussa $\mathrm{P}-25^{\circledR} \mathrm{TiO}_{2}$ nanopowder as the maximally effective photo catalyst for our experimental conditions. 
Table 12 - Microbial growth for Pseudomonas aeruginosa strain ATCC 9023, with the initial concentration of $10^{7} \mathrm{CFU} \mathrm{mL^{-1 }}$ at $0.50 \mathrm{ml} / \mathrm{L}$ of the MTBE water solution

Таблица 12 - Рост микроорганизмов итамма бактерий Pseudomonas aeruginosa ATCC 9023 с начальной концентрацией $10^{7} \mathrm{CFU} \mathrm{mL} \mathrm{m}^{-1}$ на 0,50 ml/L водного раствора МТБЭ

Табела 12 - Микробни раст за сој бактерије Pseudomonas aeruginosa ATCC 9023 почетне концентрације од $10^{7} \mathrm{CFU} \mathrm{mL}^{-1}$ у воденом раствору МТБЕ-а концентрације од $0,50 \mathrm{ml} / \mathrm{L}$

\begin{tabular}{|c|c|c|c|c|c|c|c|}
\hline $\begin{array}{l}\text { Serial } \\
\text { No. }\end{array}$ & $\begin{array}{l}\text { Time } \\
(\min )\end{array}$ & I sol. & II sol. & III sol. & IV sol. & V sol. & VI sol. \\
\hline 1 & 0.00 & 0.039 & 2.395 & 0.043 & 1.380 & 1.428 & 1.852 \\
\hline 2 & 15.0 & 0.050 & 2.436 & 0.040 & 1.256 & 1.461 & 1.642 \\
\hline 3 & 30.0 & 0.052 & 2.659 & 0.042 & 1.173 & 1.403 & 2.051 \\
\hline 4 & 45.0 & 0.041 & 2.659 & 0.036 & 1.438 & 1.364 & 1.623 \\
\hline 5 & 60.0 & 0.080 & 2.334 & 0.032 & 1.452 & 1.432 & 1.577 \\
\hline 6 & 75.0 & 0.098 & 2.683 & 0.046 & 1.350 & 1.375 & 1.595 \\
\hline 7 & 90.0 & 0.089 & 2.290 & 0.035 & 1.286 & 1.395 & 1.621 \\
\hline 8 & 105.0 & 0.099 & 2.232 & 0.026 & 1.387 & 1.360 & 1.502 \\
\hline 9 & 120.0 & 0.103 & 2.280 & 0.029 & 1.314 & 1.323 & 1.670 \\
\hline 10 & 135.0 & 0.129 & 2.232 & 0.074 & 1.256 & 1.265 & 1.565 \\
\hline 11 & 150.0 & 0.104 & - & 0.076 & 1.199 & 1.297 & 1.481 \\
\hline \multicolumn{8}{|c|}{ Legend (MTBE w. sol. $(\mathrm{c}=0.50 \mathrm{ml} / \mathrm{L})+\mathrm{MO}\left(\mathrm{c}=10^{7} \mathrm{CFU} \mathrm{mL} \mathrm{m}^{-1}\right)$ : } \\
\hline \multicolumn{4}{|c|}{$\begin{array}{l}\text { I sol: UV lamp without } \mathrm{TiO}_{2} \\
\text { II sol: UV lamp + } \mathrm{TiO}_{2}(1.0 \mathrm{~g} / \mathrm{L}) \text {; } \\
\text { III sol: Dark experiment (without UV lamp); }\end{array}$} & \multicolumn{4}{|c|}{$\begin{array}{l}\text { IV sol: UV lamp + } \mathrm{TiO}_{2}(0.50 \mathrm{~g} / \mathrm{L}) \\
\text { V sol: } \text { UV lamp }+\mathrm{TiO}_{2}(0.25 \mathrm{~g} / \mathrm{L}) \\
\text { VI sol: UV lamp }+\mathrm{TiO}_{2}(0.75 \mathrm{~g} / \mathrm{L})\end{array}$} \\
\hline
\end{tabular}

\section{Results of the experiments of antimicrobial activities}

The antimicrobial activities are examined by the measurement of the optical density for the MTBE solutions of Pseudomonas aeruginosa strains ATCC 9023 as the model microorganism (MO) for the first experiment. We investigated the effect of different concentrations of $\operatorname{MTBE}(0.15,0.25,0.50$ and $1.5 \mathrm{ml} / \mathrm{L})$, as well as a commercial titania catalyst (anatase, purity $99.9 \%$, Alfa Aesar Lancaster, c=0.1 g/L) and the catalyst-reagent system $\mathrm{TiO}_{2}$ and $\mathrm{FeCl}_{3}\left(\mathrm{TiO}_{2}: \mathrm{FeCl}_{3}=1: 1, \mathrm{c}=0.1 \mathrm{~g} / \mathrm{L}\right)$ on the growing of the $\mathrm{MO}$. The results were obtained by measuring the optical density in the colorimeter, at $550 \mathrm{~nm}$, and presented in Figure 13. 


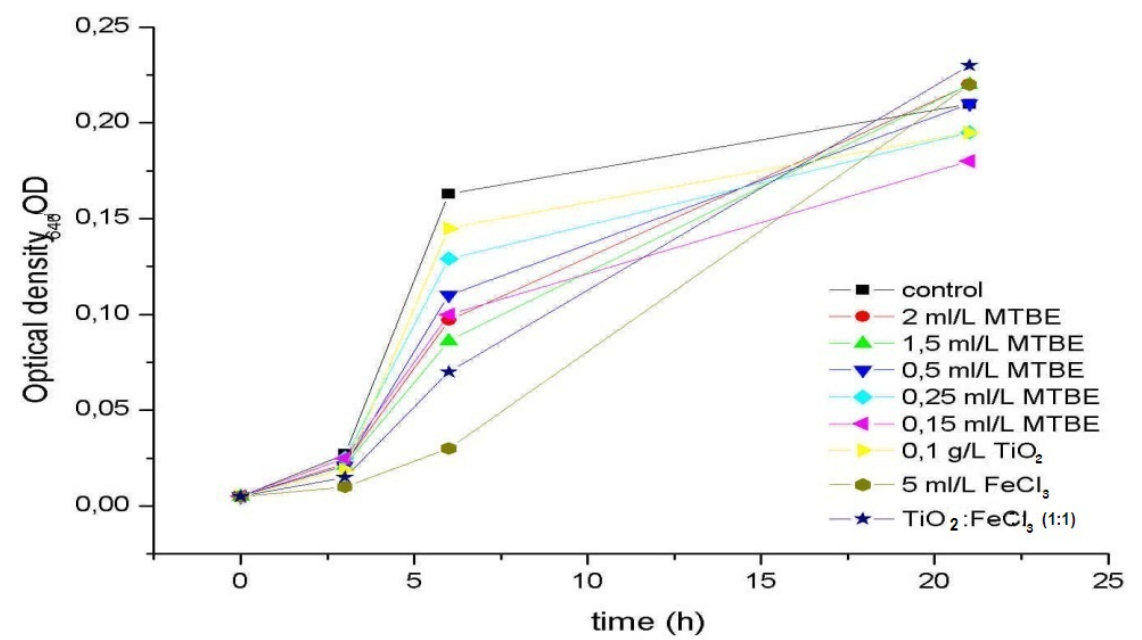

Figure 13 - The effect of different concentrations of MTBE, catalysts and reagens on the growth of Pseudomonas aeruginosa strain ATCC 9023

Pис. 13 - Влияние различных концентраций МТБЭ, катализатора и реагента на рост итамма бактерий Pseudomonas aeruginosa ATCC 9023

Слика 13 - Утицај различите концентрације МТБЕ-а, катализатора и реагенса на раст соја бактерије Pseudomonas aerugenosa ATCC 9023

Our results showed that the highest Pseudomonas aeruginosa strain ATCC 9023 growth was obtained with a high MTBE concentration of 1.5 $\mathrm{ml} / \mathrm{L}$. The Fenton reagent and the catalyst-reagent system of $\mathrm{TiO}_{2}$ and $\mathrm{FeCl}_{3}$ in the ratio of $1: 1$ have a stimulation effect on the growth of microorganisms. Finally, the best microbiological growth was achieved with the catalyst-reagent system $\mathrm{TiO}_{2}$ and $\mathrm{FeCl}_{3}$ in the ratio of $1: 1$, which can be explained with a coupled stimulation influence of the Fenton reagent in a combination with anatase titania nanopowder in equal portions. It is the best nutrition for bacteria and their growth in our experiment.

In the second experiment, we measured the effect of different types and concentrations of catalysts on antimicrobial activities of Pseudomonas aeruginosa strain DV 2739, as a model microorganism. We studied six different catalysts, such as titania nanopower catalysts: commercial titania anatase nanopowder (A), titania power Degussa P$25^{\circledR}$, the catalyst-reagent system of anatase $\mathrm{TiO}_{2}$ and $\mathrm{FeCl}_{3}$ in the ratio of 1:1 (A-Fe), synthetised nanopower $\mathrm{TiO}_{2}$ ( $\mathrm{S} 11$ sample), synthetised nanopower $\mathrm{TiO}_{2}$ doped with 2.5 wt. \% of $\mathrm{Fe}^{3+}$ (S24 sample, duration time 
of $7 \mathrm{~h}$ ) and synthetised nanopower $\mathrm{TiO}_{2}$ doped with 5.0 wt. \% of $\mathrm{La}^{3+}$ (S16 sample, duration time of $7 \mathrm{~h}$ ), all in four concentrations of $0.05,0.1,0.2$ and $0.25 \mathrm{mg} / \mathrm{L}$. The quantified results of the measurements on the colorimeter are shown in the following Tables (Tab. 13 to Tab. 16).

Table 13 - The effect of $c=0.05 \mathrm{mg} / \mathrm{L}$ of different catalyst types on the microbial growth for Pseudomonas aeruginosa strain DV 2739, with the initial concentration of $10^{7} \mathrm{CFU}$ $\mathrm{mL}^{-1}$ at $1.00 \mathrm{ml} / \mathrm{L}$ of the MTBE water solution

Таблица 13 - Влияние $c=0.05 \mathrm{mg} / \mathrm{L}$ различных типов катализаторов на рост uтамма бактерий Pseudomonas Aeruginosa DV 2739, с начальной концентрацией

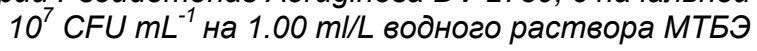

Табела 13 - Утицај различитих типова катализатора концентрације од 0.05 mg/L на микробни раст за сој бактерије Pseudomonas aerugenouse DV 2739,

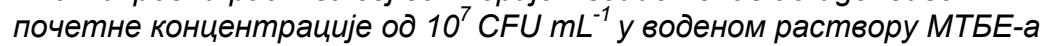
концентрације од $1,00 \mathrm{ml} / \mathrm{L}$

\begin{tabular}{|c|c|c|c|c|c|c|c|c|}
\hline \multirow[b]{2}{*}{$\begin{array}{l}\text { Time } \\
\text { (h) }\end{array}$} & \multicolumn{8}{|c|}{$0.05 \mathrm{mg} / \mathrm{L}$ catalysts } \\
\hline & $A$ & P-25 & S11 & S24 & S16 & $\mathrm{A}-\mathrm{Fe}$ & $\begin{array}{l}\text { K (only } \\
\text { TSB } \\
\text { base) }\end{array}$ & $\begin{array}{l}\mathrm{K}_{1}(\mathrm{TSB} \\
\text { base + } \\
\text { MTBE })\end{array}$ \\
\hline 0 & 0.025 & 0.110 & 0.000 & - & - & 0.040 & 0.000 & 0.005 \\
\hline 1 & 0.060 & 0.115 & 0.010 & 0.010 & 0.045 & 0.060 & 0.000 & 0.020 \\
\hline 2 & 0.045 & 0.115 & 0.015 & 0.015 & 0.055 & 0.065 & 0.000 & 0.005 \\
\hline 3 & 0.045 & 0.125 & 0.018 & 0.015 & 0.050 & 0.072 & 0.000 & 0.010 \\
\hline \multicolumn{9}{|c|}{ After 20 h, we added Pseudomonas aeruginosa strain DV 2739 (MO) } \\
\hline \multirow[b]{2}{*}{$\begin{array}{l}\text { Time } \\
\text { (h) }\end{array}$} & \multicolumn{8}{|c|}{$0.05 \mathrm{mg} / \mathrm{L}$ titania powder and titania based catalysts } \\
\hline & A & P-25 & S11 & S24 & S16 & $\mathrm{A}-\mathrm{Fe}$ & $\begin{array}{l}\text { K (only } \\
\text { TSB } \\
\text { base) }\end{array}$ & $\begin{array}{l}\mathrm{K}_{1}(\mathrm{TSB} \\
\text { base + } \\
\text { MTBE) }\end{array}$ \\
\hline 20 & 0.062 & 0.125 & 0.020 & 0.027 & 0.045 & 0.065 & 0.010 & 0.020 \\
\hline 24 & 0.290 & 0.360 & 0.275 & 0.280 & 0.310 & 0.335 & 0.270 & 0.280 \\
\hline 25 & 0.315 & 0.380 & 0.270 & 0.280 & 0.310 & 0.320 & 0.270 & 0.280 \\
\hline 26 & 0.310 & 0.370 & 0.270 & 0.280 & 0.320 & 0.330 & 0.280 & 0.290 \\
\hline 27 & 0.310 & 0.360 & 0.270 & 0.280 & 0.310 & 0.330 & 0.290 & 0.295 \\
\hline 44 & 0.300 & 0.360 & 0.250 & 0.275 & 0.300 & 0.330 & 0.260 & 0.270 \\
\hline 47 & 0.280 & 0.360 & 0.260 & 0.265 & 0.310 & 0.325 & 0.250 & 0.265 \\
\hline 49 & 0.280 & 0.360 & 0.240 & 0.270 & 0.290 & 0.320 & 0.250 & 0.260 \\
\hline 51 & 0.280 & 0.360 & 0.255 & 0.255 & 0.300 & 0.320 & 0.255 & 0.260 \\
\hline grow & 0.255 & 0.250 & 0.255 & 0.255 & 0.255 & 0.280 & 0.255 & 0.255 \\
\hline
\end{tabular}


Table 14 - The effect of $c=0.10 \mathrm{mg} / \mathrm{L}$ of different catalyst types on the microbial growth for Pseudomonas aeruginosa strain DV 2739, with the initial concentration of $10^{7}$ CFU $\mathrm{mL}^{-1}$ at $1.00 \mathrm{ml} / \mathrm{L}$ of the MTBE water solution

Таблица 14 - Влияние $c=0.10 \mathrm{mg} / \mathrm{L}$ различных типов катализаторов на $\mathrm{pocm}$ uтамма бактерий Pseudomonas Aeruginosa DV 2739, с начальной концентрацией $10^{7} \mathrm{CFU} \mathrm{mL} \mathrm{m}^{-1}$ на $1.00 \mathrm{ml} / \mathrm{L}$ водного раствора МТБЭ

Табела 14 - Утицај различитих типова катализатора концентрације од 0.10 mg/L на микробни раст за сој бактерије Pseudomonas aerugenouse DV 2739,

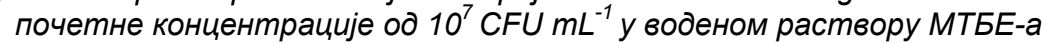
концентрације од 1,00 m//L

\begin{tabular}{|c|c|c|c|c|c|c|c|c|}
\hline \multirow[b]{2}{*}{$\begin{array}{l}\text { Time } \\
\text { (h) }\end{array}$} & \multicolumn{8}{|c|}{$0.10 \mathrm{mg} / \mathrm{L}$ catalysts } \\
\hline & A & P-25 & S11 & S24 & S16 & $\mathrm{A}-\mathrm{Fe}$ & $\begin{array}{l}\text { K (only } \\
\text { TSB base) }\end{array}$ & $\begin{array}{l}\mathrm{K}_{1}(\mathrm{TSB} \\
\text { base + } \\
\text { MTBE) }\end{array}$ \\
\hline 0 & 0.155 & 0.190 & 0.032 & 0.015 & 0.030 & 0.175 & 0.000 & 0.005 \\
\hline 1 & 0.175 & 0.200 & 0.040 & 0.030 & 0.055 & 0.207 & 0.000 & 0.020 \\
\hline 2 & 0.200 & 0.195 & 0.055 & 0.040 & 0.055 & 0.210 & 0.000 & 0.005 \\
\hline 3 & 0.210 & 0.200 & 0.055 & 0.035 & 0.060 & 0.220 & 0.000 & 0.010 \\
\hline \multicolumn{9}{|c|}{ After 20 h, we added Pseudomonas aeruginosa strain DV 2739 (MO) } \\
\hline \multirow[b]{2}{*}{$\begin{array}{l}\text { Time } \\
\text { (h) }\end{array}$} & \multicolumn{8}{|c|}{$0.10 \mathrm{mg} / \mathrm{L}$ titania powder and titania based catalysts } \\
\hline & A & P-25 & S11 & S24 & S16 & A-Fe & $\begin{array}{l}\mathrm{K} \text { (only } \\
\text { TSB base) }\end{array}$ & $\begin{array}{l}\mathrm{K}_{1}(\mathrm{TSB} \\
\text { base + } \\
\text { MTBE) }\end{array}$ \\
\hline 20 & 0.200 & 0.200 & 0.055 & 0.033 & 0.040 & 0.195 & 0.010 & 0.020 \\
\hline 24 & 0.430 & 0.430 & 0.320 & 0.300 & 0.315 & 0.440 & 0.270 & 0.280 \\
\hline 25 & 0.440 & 0.420 & 0.310 & 0.280 & 0.310 & 0.430 & 0.270 & 0.280 \\
\hline 26 & 0.440 & 0.420 & 0.320 & 0.290 & 0.310 & 0.460 & 0.280 & 0.290 \\
\hline 27 & 0.440 & 0.420 & 0.310 & 0.310 & 0.310 & 0.450 & 0.290 & 0.295 \\
\hline 44 & 0.420 & 0.420 & 0.310 & 0.280 & 0.310 & 0.470 & 0.260 & 0.270 \\
\hline 47 & 0.410 & 0.410 & 0.300 & 0.275 & 0.300 & 0.430 & 0.250 & 0.265 \\
\hline 49 & 0.410 & 0.410 & 0.290 & 0.285 & 0.300 & 0.440 & 0.250 & 0.260 \\
\hline 51 & 0.410 & 0.420 & 0.310 & 0.290 & 0.305 & 0.440 & 0.255 & 0.260 \\
\hline grow & 0.255 & 0.230 & 0.278 & 0.275 & 0.275 & 0.265 & 0.255 & 0.255 \\
\hline
\end{tabular}


Table 15 - The effect of $c=0.20 \mathrm{mg} /$ Lof different catalyst types on the microbial growth for Pseudomonas aeruginosa strain DV 2739, with the initial concentration of $10^{7} \mathrm{CFU} \mathrm{mL}$ at $1.00 \mathrm{ml} / \mathrm{L}$ of the MTBE water solution

Таблица 15 - Влияние $c=0.20 \mathrm{mg} / \mathrm{L}$ различных типов катализаторов на $\mathrm{pocm}$ uтамма бактерий Pseudomonas Aeruginosa DV 2739, с начальной концентрацией $107 \mathrm{CFU} \mathrm{mL}-1$ на $1.00 \mathrm{ml} / \mathrm{L}$ водного раствора МТБЭ

Табела 15 - Утицај различитих типова катализатора кониентрације од 0.20 mg/L на микробни раст за сој бактерије Pseudomonas aerugenouse DV 2739,

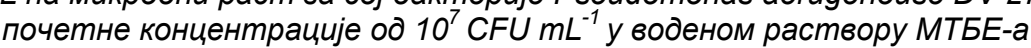
концентрације од $1,00 \mathrm{ml} / \mathrm{L}$

\begin{tabular}{|c|c|c|c|c|c|c|c|c|}
\hline \multirow[b]{2}{*}{$\begin{array}{l}\text { Time } \\
\text { (h) }\end{array}$} & \multicolumn{8}{|c|}{$0.20 \mathrm{mg} / \mathrm{L}$ catalysts } \\
\hline & Anat & P-25 & S11 & S24 & S16 & $\mathrm{A}-\mathrm{Fe}$ & $\begin{array}{l}\text { K (only } \\
\text { TSB } \\
\text { base) }\end{array}$ & $\begin{array}{l}\mathrm{K}_{1}(\mathrm{TSB} \\
\text { base + } \\
\text { MTBE) }\end{array}$ \\
\hline 0 & 0.190 & 0.275 & 0.053 & 0.046 & 0.085 & 0.160 & 0.000 & 0.005 \\
\hline 1 & 0.210 & 0.300 & 0.072 & 0.080 & 0.125 & 0.207 & 0.000 & 0.020 \\
\hline 2 & 0.250 & 0.300 & 0.080 & 0.080 & 0.125 & 0.210 & 0.000 & 0.005 \\
\hline 3 & 0.240 & 0.300 & 0.083 & 0.080 & 0.116 & 0.260 & 0.000 & 0.010 \\
\hline \multicolumn{9}{|c|}{ After 20 h, we added Pseudomonas aeruginosa strain DV 2739 (MO) } \\
\hline \multirow[b]{2}{*}{$\begin{array}{l}\text { Time } \\
\text { (h) }\end{array}$} & \multicolumn{8}{|c|}{$0.20 \mathrm{mg} / \mathrm{L}$ titania powder and titania based catalysts } \\
\hline & A & P-25 & S11 & S24 & S16 & A-Fe & $\begin{array}{l}\text { K (only } \\
\text { TSB } \\
\text { base) }\end{array}$ & $\begin{array}{l}\mathrm{K}_{1}(\mathrm{TSB} \\
\text { base + } \\
\text { MTBE) }\end{array}$ \\
\hline 20 & 0.240 & 0.310 & 0.080 & 0.086 & 0.105 & 0.220 & 0.010 & 0.020 \\
\hline 24 & 0.460 & 0.480 & 0.330 & 0.340 & 0.345 & 0.450 & 0.270 & 0.280 \\
\hline 25 & 0.470 & 0.500 & 0.320 & 0.350 & 0.355 & 0.460 & 0.270 & 0.280 \\
\hline 26 & 0.470 & 0.490 & 0.320 & 0.350 & 0.350 & 0.460 & 0.280 & 0.290 \\
\hline 27 & 0.465 & 0.490 & 0.330 & 0.350 & 0.350 & 0.440 & 0.290 & 0.295 \\
\hline 44 & 0.440 & 0.490 & 0.320 & 0.360 & 0.350 & 0.460 & 0.260 & 0.270 \\
\hline 47 & 0.430 & 0.480 & 0.320 & 0.340 & 0.350 & 0.460 & 0.250 & 0.265 \\
\hline 49 & 0.435 & 0.475 & 0.310 & 0.340 & 0.340 & 0.450 & 0.250 & 0.260 \\
\hline 51 & 0.430 & 0.490 & 0.325 & 0.350 & 0.350 & 0.470 & 0.255 & 0.260 \\
\hline grow. & 0.240 & 0.215 & 0.272 & 0.304 & 0.265 & 0.310 & 0.255 & 0.255 \\
\hline
\end{tabular}


Table 16 - The effect of $c=0.25 \mathrm{mg} / \mathrm{L}$ of different catalyst types on the microbial growth for Pseudomonas aeruginosa strain DV 2739, with the initial concentration of $10^{7} \mathrm{CFU}$ $\mathrm{mL}^{-1}$ at $1.00 \mathrm{ml} / \mathrm{L}$ of the MTBE water solution

Таблица 16 - Влияние c=0.25 mg/L различных типов катализаторов на рост uтамма бактерий Pseudomonas Aeruginosa DV 2739, с начальной концентрацией 107 CFU mL-1 на $1.00 \mathrm{ml} / \mathrm{L}$ водного раствора МТБЭ

Табела 16 - Утицај различитих типова катализатора концентрације од 0.25 mg/L на микробни раст за сој бактерuје Pseudomonas aerugenouse DV 2739,

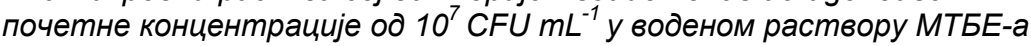
концентрације од $1,00 \mathrm{ml} / \mathrm{L}$

Time

$0.25 \mathrm{mg} / \mathrm{L}$ catalysts

(h)

\begin{tabular}{l|l|l|} 
A & P-25 & S1 \\
\hline
\end{tabular}

\begin{tabular}{|l|l|}
\hline 0 & 0.38 \\
\hline 1 & 0.4
\end{tabular}

\begin{tabular}{l|l|l}
0 & 0.380 & 0.62 \\
\hline 1 & 0.410 & 0.64 \\
\hline
\end{tabular}

\begin{tabular}{|l|l}
\hline 1 & 0.410 \\
\hline 2 & $0.42 C$ \\
\hline 3 & $0.44 C$ \\
\hline
\end{tabular}

0.410

\begin{tabular}{ll|l|l|l}
0.440 & 0.640 & 0.095
\end{tabular}

After $20 \mathrm{~h}$, we added Pseudomonas aeruginosa strain DV 2739 (MO)

\begin{tabular}{l|l}
\hline & $0.25 \mathrm{mg} / \mathrm{L}$ titania powder and titania based catalysts
\end{tabular}

(h)

A

\begin{tabular}{l|l|l|l} 
A & P-25
\end{tabular}

\begin{tabular}{|l|l|l|l|l|l|l|l|l|}
\hline 20 & 0.430 & 0.650 & 0.100 & 0.127 & 0.185 & 0.520 & 0.010 & 0.020 \\
\hline 24 & 0.630 & 0.750 & 0.290 & 0.380 & 0.445 & 0.690 & 0.270 & 0.280 \\
\hline 25 & 0.640 & 0.740 & 0.330 & 0.380 & 0.455 & 0.675 & 0.270 & 0.280 \\
\hline 26 & 0.640 & 0.740 & 0.350 & 0.370 & 0.460 & 0.680 & 0.280 & 0.290 \\
\hline 27 & 0.630 & 0.740 & 0.330 & 0.380 & 0.450 & 0.690 & 0.290 & 0.295 \\
\hline 44 & 0.620 & 0.775 & 0.340 & 0.400 & 0.460 & 0.700 & 0.260 & 0.270 \\
\hline 47 & 0.620 & 0.750 & 0.340 & 0.380 & 0.460 & 0.710 & 0.250 & 0.265 \\
\hline 49 & 0.620 & 0.760 & 0.340 & 0.390 & 0.450 & 0.700 & 0.250 & 0.260 \\
\hline 51 & 0.620 & 0.760 & 0.330 & 0.380 & 0.460 & 0.720 & 0.255 & 0.260 \\
\hline grow. & 0.240 & 0.140 & 0.270 & 0.270 & 0.285 & 0.180 & 0.255 & 0.255 \\
\hline
\end{tabular}

The results of our experimental research of the influence of the types and different concentrations of catalysts on the increase of the MO growth showed the following:

1. Catalyst concentration of 0.05 : The best MO growth at the lowest catalyst concentration is obtained for the samples in this order: S24 \& S11 (identical values), then A (titania powder anatase), P-25 (Degussa P-25 ${ }^{\circledR}$ ) and A-Fe (catalyst system titania powder anatase $-\mathrm{FeCl}_{3}$ ); 
2. Catalyst concentration of 0.10 : The best $\mathrm{MO}$ growth at the catalyst concentration of $0.10 \mathrm{~g} / \mathrm{L}$ is obtained for the samples in this order: S24 (titania doped $\mathrm{Fe}^{3+}$ ), then S11 (titania nanopower), S16 (titania doped $\mathrm{La}^{3+}$ ), A, A-Fe and P-25;

3. Catalyst concentration of 0.20 : The best $\mathrm{MO}$ growth at the catalyst concentration of $0.20 \mathrm{~g} / \mathrm{L}$ is obtained for the samples in this order: S24, then S16, S11, A-Fe, A, and P-25;

4. Catalyst concentration of 0.25 : The best $\mathrm{MO}$ growth at the catalyst concentration of $0.25 \mathrm{~g} / \mathrm{L}$ is obtained for the samples in this order: S11, then S24, S16, A, A-Fe, and P-25.

Based on these results from Table 13 to Table 16, it can be concluded that the optical density drops between 26 and 27 hours after the start of the experiment, i.e. between 6 and 7 after adding the MO for all concentrations, there was a decrease in optical density in all samples. Nevertheless, S11, S16 and S24 samples showed tendencies for growth after this fall, which suggests that these samples represent suitable catalysts for the coupled photocatalytic-microbiological experiment. The catalyst-reagent system of $\mathrm{TiO}_{2}-\mathrm{FeCl}_{3}$ in the ratio of $1: 1$ achieved very similar results for the $0.20 \mathrm{mg} / \mathrm{L}$ catalyst concentration. The best $\mathrm{MO}$ growth was obtained in $\mathrm{S} 16$ for the $0.25 \mathrm{mg} / \mathrm{L}$ catalyst concentration.

Also, S11, S16 and S24 samples showed the same tendency in contrast to the other catalysts used in which optical density increased during the entire experiment of $0.25 \mathrm{mg} / \mathrm{L}$. Therefore, the best antimicrobial activity is obtained in S24 sample; it has also been shown that $0.25 \mathrm{mg} / \mathrm{L}$ could be toxic for microorganisms, and our subsequent research using more sophisticated instrumental techniques can confirm it.

\section{Correlation between the results}

Correlating the parameters of the sol-gel synthesis process with the resulting properties of nanostructure systems is necessary for the understanding and systematic control of the nanomaterial properties and their quality. Namely, the control of particle size distribution and aggregate structure is the key criterion for product quality. This section describes the influence of the variation of some synthesis parameters on the change in the structural properties of the obtained anatase nanoparticles, examined by XRD, Raman spectroscopy and the BET analysis of their photocatalytic and microbiological activity. Both XRD and Raman spectroscopy could enable more precise determination of the average particle size, compared to AFM measurements (Golubović et al, 
2009a). In the obtained AFM images, it was not possible to detect subtle variations in the particle size, of the order of few nanometers.

The presented results and the results reported earlier by Golubovic et al (Golubović et al, 2009a) have shown that the properties of $\mathrm{TiO}_{2}$ nanoparticles depend on a few parameters of the sol-gel synthesis process. The nanoparticles size and content of brookite in the produced nanoparticles are the result of a subtle interplay between many synthesis parameters such as the type of the precursor, the temperature and the heating rate of the calcination process and the $\mathrm{pH}$ value of the hydrothermal solution. It is important to be able to investigate partial influence of the parameters on the efficiency of catalysts.

The influence of the calcination temperature on the anatase nanoparticles size, as reported by Gouadec et al (Gouadec et al, 2007), Bersani et al (Bersani et al, 1998) and Golubovic et al (Golubović et al, 2009a), shows a tendency of the particle size to increase with an increase in calcination temperature. When all other synthesis parameters are fixed, a higher calcination temperature leads to the formation of larger nanoparticles, as shown by Golubovic et al. (Golubović et al, 2009a). This is confirmed by our results shown in Table 3 and Table 7.

The $\mathrm{pH}$ value shown can influence significantly the polymorphous structure of $\mathrm{TiO}_{2}$ nanopowders: low and neutral $\mathrm{pH}$ values result in the production of $\mathrm{TiO}_{2}$ nanopowders containing brookite and sometimes rutile, while the alkali solution with a high $\mathrm{pH}$ value leads to the formation of anatase nanoparticles with high stability during calcination (Ovenstone \& Yanagisawa, 1999). The $\mathrm{pH}$ value was set to 9.3 for the synthesis of titania nanoparticles, pure and dopants. Based on the data shown in Table 3, It seems that the alkali $\mathrm{pH}$ value is not high enough to avoid the formation of brookite from the $\mathrm{TiCl}_{4}$ precursor although the literature suggested (Pottier, a. et al. 2001) that brookite phase was observed only in acidic solutions.

Therefore, we fixed the parameters, such as the $\mathrm{pH}$ value at 9.3, in order to obtain a single-digit result of the influence of the key parameters on the catalytic efficiency and the microbial activity and inactivity, i.e. its dependence on the dopant concentration, calcination duration, calcination temperature and their free surface of the mesoporous catalyst $\left(S_{\mathrm{BET}}\right)$. Our results showed that the values of $\mathrm{S}_{\mathrm{BET}}$ in the La-doped samples (S18 and S28), 79 and $84 \mathrm{~m}^{2} \mathrm{~g}^{-1}$, respectively, are higher than those in pure $\mathrm{TiO}_{2}$ nanoparticle samples (S05, S06 and S11), 17, 51 and $58 \mathrm{~m}^{2} \mathrm{~g}^{-1}$, respectively. It explains the best photocatalytic activity of S28 sample in Table 8. It explains that the particle size and its free surface are the key factor for photocatalytic and antimicrobial activities. The best 
performance of $\mathrm{S} 111$ sample in all experiments is shown from Figure 9 to Figure 12, as a comparison between S18 and S111 samples. When we compare S93 and S96 samples (Table 10) synthetized using different duration times ( 7 and $24 \mathrm{~h}$, respectively), our results show different degradation rate forthe $\mathrm{TiO}_{2}$ doped with $\mathrm{V}^{3+}$ of 10.0 wt. \%, which can be explained by the anomalies in the behavior of the photocatalyst synthetized at higher calcination temperature. We expected that S96 sample would have higher activity than S93 sample due to its heating rates during the calcination process $\left(135\right.$ and $67.5^{\circ} \mathrm{C} / \mathrm{h}$, respectively). If we compare our results from the preliminary study reported earlier (Kuburovic et al, 2009) with the results from Table 8 to Table 10, a higher degradation rate with a lower catalyst concentration loading can be explained with a synergetic influence of the aerobic condition effect and a slightly higher temperature $\left(\Delta T=5^{\circ} \mathrm{C}\right)$ in the photocatalytic activity experiments. In addition, the photocatalytic and photothermolytic effects on the degradation of MTBE in water should be considered at elevated temperatures in aerobic conditions. The further detailed research will explain the impact of values of the parameters of different processes in order to obtain the optimum values for the parameters for photocatalytic, microbiological and their antimicrobial activities.

\section{Conclusion}

Mesoporous pure as well as La, Fe and V-doped titanium (IV) oxide nanoparticle photo catalysts prepared by the sol-gel method have been extensively characterized by various sophisticated techniques and their photocatalytic and antimicrobial activities tested. The photocatalytic activity, microbiological activity and inactivity in the bath slurry-catalyst circular photoreactor were researched in detail and gave us the directions for a further study of titania-based catalysts.

We investigated the photocatalytic activity of titania doped with different concentrations of lanthanum. It was shown that the best photocatalytic efficiency was obtained with $\mathrm{TiO}_{2}$ doped with $\mathrm{La}^{3+}$ of 1 wt. $\%$ for 45 minutes, but the fastest drop in the polluted MTBE concentration in the water solution was achieved by $\mathrm{TiO}_{2}$ doped with $\mathrm{La}^{3+}$ of $3 \mathrm{wt}$. \%. These results also showed the fastest drop during the photocatalytic degradation of MTBE in the water solution in $\mathrm{S} 93$ sample $\left(\mathrm{TiO}_{2}\right.$ doped with $\mathrm{V}^{3+}$ of 10.0 wt. \%), and then in 28 sample $\left(\mathrm{TiO}_{2}\right.$ doped with $\mathrm{La}^{3+}$ of 1.0 wt. \%) for 45 minutes. Our results also show different degradation rates for $\mathrm{TiO}_{2}$ doped with $\mathrm{V}^{3+}$ of 10.0 wt. \%, S93 and S96 samples synthetized with different duration times ( 7 and $24 \mathrm{~h}$, respectively) and 
calcination heating rates $\left(66.7\right.$ and $135^{\circ} \mathrm{C} / \mathrm{h}$, respectively), which can explain their anomalous behavior. The best photocatalytic efficiency is achieved with S111 sample, which can be explained by its drastically improved adsorption and superior activity of the Fe-dopant of titania nanoparticles owing to its unique half-filled electronic configuration and shallow trapping compared to other metal dopants tested in our study.

Our results showed that the best coupled photocatalyticmicrobiological properties are achieved when we use direct ultraviolet radiation simulated with the sodium lamp SONT UV400 with the initial concentration of $0.75 \mathrm{~g} / \mathrm{L}$ Degussa $\mathrm{P}-25^{\circledR} \mathrm{TiO}_{2}$ nanopowder for 60 and 150 minutes. These results show that $\mathrm{TiO}_{2}$ and direct ultraviolet radiation simulated with the sodium lamp SONT UV400 in lab conditions and titania in the concentration of $1.0 \mathrm{~g} / \mathrm{L}$ have the effect of inactivating and killing microorganisms. The optical density results have proven this assertion by measuring the microbial activity and inactivity in the coupled photocatalytic-microbiological experiment. We also studied the antimicrobial activity of Pseudomonas aeruginosa strain DV 2739 which was seeded with different concentrations of MTBE and catalysts. The biggest Pseudomonas aeruginosa strain DV 2739 growth was obtained with a high MTBE concentration of $1.5 \mathrm{ml} / \mathrm{L}$. The Fenton reagent and the catalyst-reagent system of $\mathrm{TiO}_{2}$ and $\mathrm{FeCl}_{3}$ in the ratio of $1: 1$ have a stimulation effect on the growth of microorganisms. Finally, the best microbiological growth was achieved with the catalyst-reagent system of $\mathrm{TiO}_{2}$ and $\mathrm{FeCl}_{3}$ in the ratio of $1: 1$, which can be explained by the coupled stimulation influence of the Fenton reagent and anatase titania nanopowder in equal portions. It is the best nutrition for bacteria and their growth in our experiment. In accordance with the results in the previous experiment, we expected that the $\mathrm{TiO}_{2}$ nanoparticles doped with $\mathrm{Fe}^{3+}$ can give the best growth of microorganisms. It was the reason for the research and testing different concentrations of $\mathrm{TiO}_{2}$ nanoparticle catalysts carried out in another experiment in order to obtain the optimum concentration and type of catalyst for antimicrobial activity, as well as the limits which microorganisms can reach to give them the best performance for the coupled photocatalytic-microbiological experiments. Based on these results, it can be determined that the optical density drops between 26 and 27 hours after the start of the experiment, i.e. between 6 and 7 after adding the MO. For all concentrations, there was a decrease in optical density in all samples. Nevertheless, S11, S16 and S24 samples showed tendencies for growth after this fall, which suggests that these samples represent suitable catalysts for coupled photocatalytic-microbiological experiments. The catalyst-reagent system 
of $\mathrm{TiO}_{2}-\mathrm{FeCl}_{3}$ in the ratio of $1: 1$ achieved very similar results for the catalyst concentration of $0.20 \mathrm{mg} / \mathrm{L}$. The best $\mathrm{MO}$ growth was obtained in $\mathrm{S} 16$ for $0.25 \mathrm{mg} / \mathrm{L}$ catalyst concentration. So, the best antimicrobial activity was obtained in S24 sample; it was also shown that $0.25 \mathrm{mg} / \mathrm{L}$ could be toxic for microorganisms, and our subsequent research using more sophisticated instrumental techniques can confirm it. The results showed that the effect of the optical density concentration and the MO growth is in a direct correlation with the structure of $\mathrm{TiO}_{2}$ nanoparticle catalyst and the doper metal type.

Our results of the superior Fe-dopant characteristics together with the theoretical knowledge on $\mathrm{TiO}_{2}$ nanoparticles doped with $\mathrm{Ag}$ (van Grieken et al, 2009), (Ménesi et al, 2009), Au (Huang et al, 2006) and Fe (Flak et al, 2015) give us directions for further studies of their photocatalytic and antimicrobial activities, as well as for the development of $\mathrm{TiO}_{2-}$ nanoparticles and nanotubes for enhancing antibiotics and their use in the cancer treatment. Finally, in our further studies, we will research in detail the impact of different values of the parameters of different processes such as irradiance wavelength, light penetration and irradiance intensity, Influence of temperature, substrate concentration and chemical characteristics, retention time, flow, temperature and $\mathrm{pH}$ value, initial concentration of the compound and the catalyst, dissolved oxygen, optimal areas of wavelength radiation for individual phases decomposition process, absorption and selective absorption, etc. in order to obtain the optimum values for the parameters for photocatalytic, microbiological and antimicrobial activities, as well as their synergetic effects for their environmental and biomedical applications in real conditions. All this will ultimately explain the mechanisms of these processes.

\section{References}

Ahonen, P.P., Kauppinen, E.I., Joubert, J.C., Deschanvres, J.L., \& Tendeloo, G.V. 1999. Preparation of nanocrystalline titania powder via aerosol pyrolysis of titanium tetrabutoxide. Journal of Materials Research, 14(10), pp.3938-3948. Available at: https://doi.org/10.1557/jmr.1999.0533.

Alivisatos, A.P. 1996. Semiconductor Clusters, Nanocrystals, and Quantum Dots of the Total Environment. Science, 271(5251), pp.933-937. Available at: https://doi.org/10.1126/science.271.5251.933. 
Androutsopoulos, G.P., \& Salmas, C.E. 2000. A New Model for Capillary Condensation-Evaporation Hysteresis Based on a Random Corrugated Pore Structure Concept: Prediction of Intrinsic Pore Size Distributions. 1. Model Formulation. Industrial \& Engineering Chemistry Research, 39(10), pp.37473763. Available at: https://doi.org/10.1021/ie0001624.

Aruna, S.T., Tirosh, S., \& Zaban, A. 2000. Nanosize rutile titania particle synthesis via a hydrothermal method without mineralizers. Journal of Materials Chemistry, 10(10), pp.2388-2391. Available at: https://doi.org/10.1039/b001718n.

Backman, U., Tapper, U., \& Jokiniemi, J.K. 2004. An aerosol method to synthesize supported metal catalyst nanoparticles. Synthetic Metals, 142(1-3), pp.169-176. Available at: https://doi.org/10.1016/j.synthmet.2003.08.007.

Barrett, E.P., Joyner, L.G., \& Halenda, P.P. 1951. The Determination of Pore Volume and Area Distributions in Porous Substances. I. Computations from Nitrogen Isotherms. Journal of the American Chemical Society, 73(1), pp.373-380. Available at: https://doi.org/10.1021/ja01145a126.

Bersani, D., Lottici, P.P., Lopez, T., \& Ding, X. 1998. A Raman Scattering Study of $\mathrm{PbTiO} 3$ and $\mathrm{TiO} 2$ Obtained by Sol-Gel. Journal of Sol-Gel Science and Technology, 13(1/3), pp.849-853. Available at: https://doi.org/10.1023/a:1008602718987.

Bhattacharyya, K., Varma, S., Tripathi, A.K., Bharadwaj, S.R., \& Tyagi, A.K. 2008. Effect of Vanadia Doping and Its Oxidation State on the Photocatalytic Activity of TiO 2 for Gas-Phase Oxidation of Ethene. The Journal of Physical Chemistry C, 112(48), pp.19102-19112. Available at: https://doi.org/10.1021/jp807860y.

Blešić, M., Šaponjić, Z., Nedeljković, J., \& Uskoković, D. 2002. $\mathrm{TiO}_{2}$ films prepared by ultrasonic spray pyrolysis of nanosize precursor. Materials Letters, 54(4), pp.298-302. Available at: https://doi.org/10.1016/s0167577x(01)00581-x.

Cai, R., Hashimoto, K., Itoh, K., Kubota, Y., \& Fujishima, A. 1991. Photokilling of Malignant Cells with Ultrafine $\mathrm{TiO}_{2}$ Powder. Bulletin of the Chemical Society of Japan, 64(4), pp.1268-1273. Available at: https://doi.org/10.1246/bcsj.64.1268. 07th.

California Code of Regulations. 1999. Title 22, Section 64449, January

Chueh, Y.L., Hsieh, C.H., Chang, M.T., Chou, L.J., Lao, C.S., Song, J.H., Gan, J.-Y., Wang, Z.L. 2007. $\mathrm{RuO}_{2}$ Nanowires and $\mathrm{RuO}_{2} / \mathrm{TiO}_{2}$ Core/Shell Nanowires: From Synthesis to Mechanical, Optical, Electrical, and Photoconductive Properties. Advanced Materials, 19(1), pp.143-149. Available at: https://doi.org/10.1002/adma.200601830.

Dinesh, G.K., Anandan, S., \& Sivasankar, T. 2015. Sonophotocatalytic treatment of Bismarck Brown $G$ dye and real textile effluent using synthesized novel $\mathrm{Fe}(0)$-doped $\mathrm{TiO}_{2}$ catalyst. RSC Advances, 5(14), pp.10440-10451. Available at: https://doi.org/10.1039/c4ra07685k.

Fernández-lbáñez, F., Malato, S., \& de Nieves, L.F.J. 2004. Propiedades coloidales de partículas de $\mathrm{TiO}_{2}$ : Aplicación al tratamiento foto catalítico solar de aguas. Madrid, Spain: CIEMAT. 
Flak, D., Coy, E., Nowaczyk, G., Yate, L., \& Jurga, S. 2015. Tuning the photodynamic efficiency of TiO 2 nanotubes against HeLa cancer cells by $\mathrm{Fe}-$ doping. RSC Advances, 5(103), pp.85139-85152. Available at: https://doi.org/10.1039/c5ra17430a.

Golubović, A., Šćepanović, M., Kremenović, A., Aškrabić, S., Berec, V., Dohčević-Mitrović, Z., \& Popović, Z.V. 2009a. Raman study of the variation in anatase structure of $\mathrm{TiO}_{2}$ nanopowders due to the changes of sol-gel synthesis conditions. Journal of Sol-Gel Science and Technology, 49(3), pp.311-319. Available at: https://doi.org/10.1007/s10971-008-1872-3.

Golubović, A., Šćepanović, M., Aškrabić, S., Grujić-Brojčin, M., DohčevićMitrović, Z., Kremenović, A., \& Popović, Z.V. 2009b. Influence of $\mathrm{La}^{3+}$-dopant on anatase nanopowders synthesized by sol-gel method. In 238th American Chemical Society National Meeting \& Exposition, Washington DC, Abstract of Scientific Papers.Washington DC. pp.INOR 1262642.

Golubović, A., Abramović, B., Šćepanović, M., Grujić-Brojčin, M., Armaković, S., Veljković, I., Babić, B., Dohčević-Mitrović, Z., Popović, Z.V. 2013. Improved efficiency of sol-gel synthesized mesoporous anatase nanopowders in photocatalytic degradation of metoprolol. Materials Research Bulletin, 48(4), pp.1363-1371. Available at: https://doi.org/10.1016/j.materresbull.2012.11.098.

Gouadec, G., \& Colomban, P. 2007. Raman Spectroscopy of nanomaterials: How spectra relate to disorder, particle size and mechanical properties. Progress in Crystal Growth and Characterization of Materials, 53(1), pp.1-56. Available at: https://doi.org/10.1016/j.pcrysgrow.2007.01.001.

van Grieken, R., Marugán, J., Sordo, C., Martínez, P., \& Pablos, C. 2009. Photocatalytic inactivation of bacteria in water using suspended and immobilized silver- $\mathrm{TiO}_{2}$. Applied Catalysis B: Environmental, 93(1-2), pp.112-118. Available at: https://doi.org/10.1016/j.apcatb.2009.09.019.

Grujić-Brojčin, M., Armaković, S., Tomić, N., Abramović, B., Golubović, A., Stojadinović, B., Šćepanović, M. 2014. Surface modification of sol-gel synthesized $\mathrm{TiO}_{2}$ nanoparticles induced by La-doping. Materials Characterization, 88, pp.3041. Available at: https://doi.org/10.1016/j.matchar.2013.12.002.

Heller, A. 1995. Chemistry and Applications of Photocatalytic Oxidation of Thin Organic Films. Accounts of Chemical Research, 28(12), pp.503-508. Available at: https://pubs.acs.org/doi/abs/10.1021/ar00060a006. Accessed: 15 May 2018.

Hoffmann, M.R., Martin, S.T., Choi, W., \& Bahnemann, D.W. 1995. Environmental Applications of Semiconductor Photocatalysis. Chemical Reviews, 95(1), pp.69-96. Available at: https://doi.org/10.1021/cr00033a004.

Huang, F., Yan, A., \& Zhao, H. 2016. Influences of Doping on Photocatalytic Properties of $\mathrm{TiO}_{2}$ Photocatalyst. In W. Cao Ed., Semiconductor Photocatalysis - Materials, Mechanisms and Applications. IntechOpen. Available at: https://doi.org/10.5772/63234. 
Huang, X., El-Sayed, I.H., Qian, W., \& El-Sayed, M.A. 2006. Cancer Cell Imaging and Photothermal Therapy in the Near-Infrared Region by Using Gold Nanorods. Journal of the American Chemical Society, 128(6), pp.2115-2120. Available at: https://doi.org/10.1021/ja057254a.

Hunter, R. 2000. Foundations of colloid Science. Oxford, Great Britain: University Press. ISBN: 9780198505020 , Second Edition.

Ireland, J., Klostermann, P., Rice, E., \& Clark, R. 1993. Inactivation of Escherichia coli by titanium dioxide photocatalytic oxidation. Applied and Environmental Microbiology, 59(5), pp.1668-1670. Available at: http://aem.asm.org/content/59/5/1668.full.pdf+html. Accessed: 15 May 2018.

Jokanović, V., Spasić, A.M., \& Uskoković, D. 2004. Designing of nanostructured hollow $\mathrm{TiO}_{2}$ spheres obtained by ultrasonic spray pyrolysis. Journal of Colloid and Interface Science, 278(2), pp.342-352. Available at: https://doi.org/10.1016/j.jcis.2004.06.008.

Kaneko, K., Ishii, C., Kanoh, H., Hanzawa, Y., Setoyama, N., \& Suzuki, T. 1998. Characterization of porous carbons with high resolution as-analysis and low temperature magnetic susceptibility. Advances in Colloid and Interface Science, 76-77, pp.295-320. Available at: https://doi.org/10.1016/s00018686(98)00050-5.

Kikuchi, Y., Sunada, K., lyoda, T., Hashimoto, K., \& Fujishima, A. 1997. Photocatalytic bactericidal effect of $\mathrm{TiO}_{2}$ thin films: dynamic view of the active oxygen species responsible for the effect. Journal of Photochemistry and Photobiology A: Chemistry, 106(1-3), pp.51-56. Available at: https://doi.org/10.1016/s1010-6030(97)00038-5.

Kuburovic, N., \& Dimitrijevic-Brankovic, S. 2006. Coupling of the photocatalytic and microbiological degradation processes for the organic pollutants destruction. In Seventh European Meeting on Environmental Chemistry (EMEC7), December 9th, Brno, Czech Republic, oral presentation OP45, pp.66.

Kuburovic, N.D., Golubovic, A., Todorovic, Z., Gasic, S., \& Solevic, T. 2009. Photocatalytic degradation of wastewater polluted by methyl-tertiary-butylether using titanium-dioxide and doped titanium-dioxide. In Proceedings of the 4th IASME/WSEAS International Conference on Water Resources, Hydraulics \& Hydrology (WHH', ISBN: 978-960-474-057-4. Cambridge, UK, pp.19-24, February 24-26.

Kuburovic, N., \& Orlovic, A. 2010. Photocatalytic wastewater treatment from sewage Belgrade. In International Conference: Wastewater, municipal solid waste and hazardous waste, $29^{\text {th }}$ March $-01^{\text {st }}$ April, Subotica, Serbia.

Kuburovic, N., Todorovic, M., Drmanic, S. Raichevic, V. And Jovanovic, Lj. 2005. Aerobic bioremediation of water polluted by methyl tertiary butyl ethers. In Proceeding of the $2^{\text {nd }}$ World Conference on Biomass for Energy, Industry and Climate protection, Italy, pp.1608-1611. 
Kuburovic, N., Todorovic, M., Raicevic, V., Orlovic, A., Jovanovic, Lj., Nikolic, J.,..., Solevic, T. 2007. Removal of methyl tertiary butyl ether from wastewaters using photolytic, photocatalytic and microbiological degradation processes. Desalination, 213(1-3), pp.123-128. Available at: https://doi.org/10.1016/j.desal.2006.03.605.

Lakshmi, B.B., Dorhout, P.K., \& Martin, C.R. 1997. Sol-Gel Template Synthesis of Semiconductor Nanostructures. Chemistry of Materials, 9(3), pp.857-862. Available at: https://doi.org/10.1021/cm9605577.

Liu, T., \& Zhang, H. 2013. Novel Fe-doped anatase $\mathrm{TiO}_{2}$ nanosheet hierarchical spheres with $94 \%\{001\}$ facets for efficient visible light photodegradation of organic dye. RSC Advances, 3(37), p.16255. Available at: https://doi.org/10.1039/c3ra40875b.

Maness, P., Snolinski, S., Blake, D., Wolfrum, Z., \& Jacoby, W. 1999. Solar Treatment as an Alternative for Water Disinfections. Applied and Environmental Microbiology, 65(9), pp.4094-4098.

Marugán, J., van Grieken, R., Pablos, C., \& Sordo, C. 2010. Analogies and differences between photocatalytic oxidation of chemicals and photocatalytic inactivation of microorganisms. Water Research, 44(3), pp.789-796. Available at: https://doi.org/10.1016/j.watres.2009.10.022.

Matsunaga, T., \& Okochi, M. 1995. $\mathrm{TiO}_{2}$-Mediated Photochemical Disinfection of Escherichia coli Using Optical Fibers. Environmental Science \& Technology, 29(2), pp.501-505. Available at: https://doi.org/10.1021/es00002a028.

Ménesi, J., Kékesi, R., Oszkó, A., Zöllmer, V., Seemann, T., Richardt, A., \& Dékány, I. 2009. Photocatalysis on silver-layer silicate/titanium dioxide composite thin films at solid/vapour interface. Catalysis Today, 144(1-2), pp.160165. Available at: https://doi.org/10.1016/j.cattod.2009.02.030.

Nedeljković, J.M., Šaponjić, Z.V., Rakočević, Z., Jokanović, V., \& Uskoković, D.P. 1997. Ultrasonic spray pyrolysis of $\mathrm{TiO}_{2}$ nanoparticles. Nanostructured Materials, 9(1-8), pp.125-128. Available at: https://doi.org/10.1016/s0965-9773(97)00034-2.

Ollis, D.F., Pelizzetti, E., \& Serpone, N. 1991. Environmintal Applications of Semiconductor Photocatalysis. Environmental Science \& Technology, 25(9), pp.1522-1529. Available at: https://doi.org/10.1021/es00021a001.

Ohko, Y., Utsumi, Y., Niwa, C., Tatsuma, T., Kobayakawa, K., Satoh, Y., Kubota, Y., Fujishima, A. 2001. Self-sterilizing and self-cleaning of silicone catheters coated with $\mathrm{TiO}_{2}$ photocatalyst thin films: A preclinical work. Journal of Biomedical Materials Research, 58(1), pp.97-101. Available at: https://doi.org/10.1002/1097-4636(2001)58:1<97::aid-jbm140>3.0.co;2-8.

Ohsaka, T., Izumi, F., \& Fujiki, Y. 2005. Raman spectrum of anatase, $\mathrm{TiO}_{2}$. Journal of Raman Spectroscopy, 7(6), pp.321-324. Available at: https://doi.org/10.1002/jrs.1250070606.

Ovenstone, J., \& Yanagisawa, K. 1999. Effect of Hydrothermal Treatment of Amorphous Titania on the Phase Change from Anatase to Rutile during Calcination. Chemistry of Materials, 11(10), pp.2770-2774. Available at: https://doi.org/10.1021/cm990172z. 
Panic, V., Dekanski, A., Miskovic-Stankovic, V., Milonjic, S., \& Nikolic, B. 2003. The role of the concentration profile of titanium oxide on the electrochemical behavior of $\mathrm{RuO}_{2}-\mathrm{TiO}_{2}$ coatings obtained by the sol-gel procedure. Journal of the Serbian Chemical Society, 68(12), pp.979-988. Available at: https://doi.org/10.2298/0352-51390312979p.

Pontius, F.W. 1998. New horizons in federal regulation. Journal - American Water Works Association, 90(3), pp.38-50. Available at: https://doi.org/10.1002/j.1551-8833.1998.tb08394.x

Pottier, A., Chanéac, C., Tronc, E., Mazerolles, L., \& Jolivet, J. 2001. Synthesis of brookite $\mathrm{TiO}_{2}$ nanoparticles by thermolysis of $\mathrm{TiCl}_{4}$ in strongly acidic aqueous media. Journal of Materials Chemistry, 11(4), pp.1116-1121. Available at: https://doi.org/10.1039/b100435m

Ramli, R.M., Chong, F.K., Omar, A.A., \& Murugesan, T. 2014. Performance of Surfactant Assisted Synthesis of $\mathrm{Fe} / \mathrm{TiO}_{2}$ on the Photodegradation of Diisopropanolamine. CLEAN - Soil, Air, Water, 43(5), pp.690-697. Available at: https://doi.org/10.1002/clen.201300186.

Richardson, S.D. 2003. Disinfection by-products and other emerging contaminants in drinking water. TrAC - Trends in Analytical Chemistry, 22(10), pp.666-684.

Rodriguez-Carvajal, J. 2008. FullProf computer program. Available at: http://www.ill.eu/sites/fullprof/index.html. Accessed: 17 May 2018.

Salmas, C.E., \& Androutsopoulos, G.P. 2001. A Novel Pore Structure Tortuosity Concept Based on Nitrogen Sorption Hysteresis Data. Industrial \& Engineering Chemistry Research,40(2), pp.721-730. Available at: https://doi.org/10.1021/ie000626y.

Schwarzer, H., \& Peukert, W. 2005. Prediction of aggregation kinetics based on surface properties of nanoparticles. Chemical Engineering Science, 60(1), pp.11-25. Available at: https://doi.org/10.1016/j.ces.2004.06.050.

Shaffer, K.L., \& Uchrin, C.G. 1997. Uptake of Methyl Tertiary Butyl Ether (MTBE) by Groundwater Solids. Bulletin of Environmental Contamination and Toxicology, 59(5), pp.744-749. Available at: https://doi.org/10.1007/s001289900543.

Sitkiewitz, S., \& Heller, A. 1996. Photocatalytic oxidiation of benzene and steatic on sol-gel derived $\mathrm{TiO}_{2}$ thin films attached to glass. New Journal of Chemistry, 20, pp.233-241.

Squillace, P.J., Zogorski, J.S., Wilber, W.G., \& Price, C.V. 1996. Preliminary Assessment of the Occurrence and Possible Sources of MTBE in Groundwater in the United States, 1993-1994. Environmental Science \& Technology, 30(5), pp.1721-1730. Available at: https://doi.org/10.1021/es9507170.

Su, R., Bechstein, R., Kibsgaard, J., Vang, R.T., \& Besenbacher, F. 2012. Highquality $\mathrm{Fe}$-doped $\mathrm{TiO}_{2}$ films with superior visible-light performance. Journal of Materials Chemistry, 22(45), p.23755. Available at: https://doi.org/10.1039/c2jm34298g.

Su, Y., Wu, Z., Wu, Y., Yu, J., Sun, L., \& Lin, C. 2015. Acid Orange II degradation through a heterogeneous Fenton-like reaction using $\mathrm{Fe}-\mathrm{TiO}_{2}$ nanotube arrays as a photocatalyst. Journal of Materials Chemistry $A, 3(16)$, pp.8537-8544. Available at: https://doi.org/10.1039/c5ta00839e. 
Sungkaworn, T., Triampo, W., Nalakarn, P., Triampo, D., Tang, I.M., Lenbury, Y., \& Picha, P. 2008. The Effects of $\mathrm{TiO}_{2}$ Nanoparticles on Tumor Cell Colonies: Fractal Dimension and Morphological Properties. International Journal of Medical and Health Sciences, World Academy of Science, Engineering and Technology, 2(1), pp.20-27.

Šćepanović, M.J., Grujić-Brojčin, M., Dohčević-Mitrović, Z.D., \& Popović, Z.V. 2007. Temperature dependence of the lowest frequency $E_{g}$ Raman mode in laser-synthesized anatase $\mathrm{TiO}_{2}$ nanopowder. Applied Physics A, 86(3), pp.365371. Available at: https://doi.org/10.1007/s00339-006-3775-x.

Šćepanović, M., Aškrabić, S., Grujić-Brojčin, M., Golubović, A., DohčevićMitrović, Z., Matović, B., \& Popović, Z.V. 2010. Raman Study of VanadiumDoped Titania Nanopowders Synthesized by Sol-Gel Method. International Journal of Modern Physics B, 24(06n07), pp.667-675. Available at: https://doi.org/10.1142/s0217979210064289.

Takeuchi, M., Dohshi, S., Eura, T., \& Anpo, M. 2003. Preparation of Titanium-Silicon Binary Oxide Thin Film Photocatalysts by an Ionized Cluster Beam Deposition Method. Their Photocatalytic Activity and Photoinduced SuperHydrophilicity. J. Phys. Chem. B, 107 (51), pp.14278-14282. Available at: https://pubs.acs.org/doi/pdf/10.1021/jp0308514.

The Merck index: an encyclopedia of chemicals, drugs, and biologicals. 1996. Ed. Susan Budavari, Maryadele J. O'Neil, Ann Smith, Patricia E. Heckelman, Joanne F. Kinneary. Whitehouse Station, NJ: Merck \& co Inc. - 12th Edition. Available at: https://www.ncbi.nlm.nih.gov/nlmcatalog/9609686.

Uchida, H., Itoh, S., \& Yoneyama, H. 1993. Photocatalytic Decomposition of Propyzamide Using $\mathrm{TiO}_{2}$ Supported on Activated Carbon. Chemistry Letters, 22(12), pp.1995-1998. Available at: https://doi.org/10.1246/cl.1993.1995.

Waliszewski, P. 1997. Complexity, dynamic cellular network and tumourgenesis. Polish Journal of Pathology, 46, pp.235-241.

Wang, S., Lian, J.S., Zheng, W.T., \& Jiang, Q. 2012. Photocatalytic property of $\mathrm{Fe}$ doped anatase and rutile $\mathrm{TiO}_{2}$ nanocrystal particles prepared by sol-gel technique. Applied Surface Science, 263, pp.260-265. Available at: https://doi.org/10.1016/j.apsusc.2012.09.040.

Watts, R.J., Kong, S., Orr, M.P., Miller, G.C., \& Henry, B.E. 1995. Photocatalytic Degradation of Toxins Secreted to Water by Cyanobacteria and Unicellular Algae and Photocatalytic Degradation of The Cells of Selected Microorganisms. Water Research, 29(1), pp.95-100. Available at: https://doi.org/10.1016/0043-1354(94)e0122-m.

Wei, C., Lin, W.Y., Zainal, Z., Williams, N.E., Zhu, K., Kruzic, A.P., Smith R.L., Rajeshwar, K. 1994. Bactericidal Activity of $\mathrm{TiO}_{2}$ Photocatalyst in Aqueous Media: Toward a Solar-Assisted Water Disinfection System. Environmental Science \& Technology, 28(5), pp.934-938. Available at: https://doi.org/10.1021/es00054a027. 
Xu, M., Ma, J., Gu, J., \& Lu, Z. 1998. Photocatalytic $\mathrm{TiO}_{2}$ nanoparticles damage to cellular membranes and genetic supramolecules. Supramolecular Science, 5(5-6), pp.511-513. Available at: https://doi.org/10.1016/s09685677(98)00063-7.

Yan, J., Zhang, Y., Liu, S., Wu, G., Li, L., \& Guan, N. 2015. Facile synthesis of an iron doped rutile $\mathrm{TiO}_{2}$ photocatalyst for enhanced visible-lightdriven water oxidation. Journal of Materials Chemistry A,3(43), pp.2143421438. Available at: https://doi.org/10.1039/c5ta07003a.

Yao, B., Wang, L., Wang, C., Wang, Y., \& Zhao, G. 2007. Preparation and Performances of $\mathrm{RuO}_{2} / \mathrm{TiO}_{2}$ Films Photocatalyst Supported on Float Pearls. Chinese Journal of Chemical Physics, 20(6), pp.789-795. Available at: https://doi.org/10.1088/1674-0068/20/06/789-795.

Zhang, A., \& Sun, Y. 2004. Photocatalytic killing effect of $\mathrm{TiO}_{2}$ nanoparticles on Ls-174-t human colon carcinoma cells. World Journal of Gastroenterology, 10(21) pp.3191-3193.

Available

at: https://doi.org/10.3748/wjg.v10.i21.3191.

\section{РАЗРАБОТКА НОВЫХ УМНЫХ МЕТАЛЛИЧЕСКИХ} НАНОМАТЕРИАЛОВ НА ОСНОВЕ ДИОКСИДА ТИТАНА ДЛЯ ФОТОКАТАЛИТИЧЕСКОЙ И АНТИМИКРОБНОЙ АКТИВНОСТЕЙ

Наташа Д. Кубурович ${ }^{\text {, }}$ Александр В. Голубович ${ }^{б}$, Лиляна М. Бабинчев

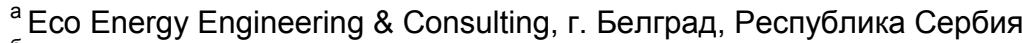

${ }^{\sigma}$ Белградский университет, Институт физических исследований, Отделение фризики твердого тела и новых материалов,

г. Белград, Республика Сербия

в Университет в г.Приштина, Факультет технических наук, г.Косовска Митровица, Республика Сербия

ОБЛАСТЬ: химическая инженерия и материаловедение, каталитические процессы и композиционные материалы

ВИД СТАТЬИ: оригинальная научная статья

ЯЗЫК СТАТЬИ: английский

Резюме:

Предметом данного исследования являются синтез, классификация и испытания наночастиц титана (IV) оксида $\left(\mathrm{TiO}_{2}-\right.$ HU-a) и легирования лантана (La3+), железа (Fe3+) и ванадия (V3+) для фоотокаталитической и микробиологической активностей, а также сравнение с каталитическим активностима испытанными в коммерческих иелях TiO2 (P25, Degussa ${ }^{\circledR}$ и наночастиц анатаза, чистоты 99,9\%, компанией Alfa Aesar из Ланкастера). Наночастицы диоксида титана были синтезированы и легированы c различной концентрацией металлических допантов, при различной продолжительности процесса прокаливания: ТіО2-HЧ 
(анатаз-HЧ, время процесса прокаливания 5 и 7 часов), La3+ (0.65, 1, 2, 3, 4, 5 и 6 вес. \%, продолжительность прокаливания 7 часов), $\mathrm{Fe} 3+(1,2,5,3,0$ и 5 вес. \%, продолжительность прокаливания 7 и 24 часа) и V3+ (10 вес. \%, продолжительность прокаливания 7 и 24 часа). Штамм „Pseudomonas aeruginosa DV 2739“ использован в качестве модели микроорганизмов 8 микробиологических экспериментах, проведенных в микробиологической лаборатории. Совместный процесс фоотокаталических и микробиологических испытаний эксперимента проводился в катализаторной ванне при прямом концентрированном ультрафиолетовом излучении от натриевой лампы SONT UV 400, симулирующей солнечное излучение. Исследование показало, что образец катализатора C28, La-легирующей примеси с концентрацией 1 вес. \%, обладает лучшими фотокаталитическими свойствами по сравнению с другими La-допантами, в то время, как лучшая фотокаталитическая активность была достигнута в образце S111, Fе-легирующей примеси диоксида титана (5 вес.\%, продолжительность прокаливания составляет 7 часов). Результаты нашего исследования также показали различную степень деградации при применении V-допанта $\mathrm{TiO}_{2} \quad \mathrm{c}$ концентрацией 10 вес.\% образцы С93 и С96 были синтезированы при различной продолжительности прокаливания (67.5 и 135 C/4, поочередно), что можно считать аномалией в их поведении. И наконец лучшая антимикробная активность получена в образце CS24, Fe-легирующей примеси, которая показала, что 0,25 мә/л является токсичным для микроорганизмов. Результаты нашего исследования о преимущественных характеристиках $\mathrm{Fe}$ легирующей примеси и теоретические знания о наночастицах $\mathrm{TiO2,} \mathrm{легированных} \mathrm{Ag}$, $\mathrm{Au}$ u $\mathrm{Fe}$, безусловно облегчат исследователям дальнейшую работу в изучении фотокаталитической и антимикробной активностей, а также развития наночастиц ТiO2 и нанотрубок, с целью усиления действия антибиотиков и их применения при лечении онкологических заболеваний.

Ключевые слова: диоксид титана, ТіО2-наночастицы, ТіО2 легированные $\mathrm{La}^{3+}, \mathrm{Fe}^{3+}$ u $\mathrm{V}^{3+}$, продолжительность прокаливания, штаммы Pseudomonas aeruginosa DV 2739 и ATCC 9023, фотокаталитическая активность, антимикробная активность. 
PAЗВОЈ НОВИХ ПАМЕТНИХ МЕТАЛНИХ НАНОМАТЕРИЈАЛА НА БАЗИ ТИТАНИЈУМ-ДИОКСИДА ЗА ФОТОКАТАЛИТИЧКУ И АНТИМИКРОБНУ АКТИВНОСТ

Наташа Д. Кубуровић $^{\mathrm{a}}$, Александар В. Голубовићб Љиљана М. Бабинчев ${ }^{\text {B }}$

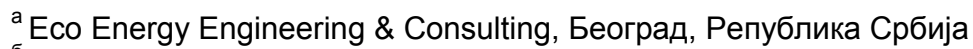

${ }^{\sigma}$ Универзитет у Београду, Институт за физику, Центар за физику чврстог стања и нове материјале, Београд, Република Србија

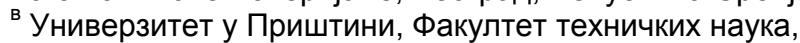
Косовска Митровица, Република Србија

ОБЛАСТ: хемијско инжењерство и инжењерство материјала, каталитички процеси и композитни материјали

ВРСТА ЧЛАНКА: оригинални научни чланак

ЈЕЗИК ЧЛАНКА: енглески

\section{Сажетак:}

Предмет ове студије била је синтеза, карактеризација и тестирање наночестица титанијум (IV) оксида (TiO ${ }_{2}-\mathrm{H}$-а) и њихових допаната лантана $\left(\mathrm{La}^{3+}\right)$, гвожђа $\left(\mathrm{Fe}^{3}+\right)$ и ванадијума $\left(\mathrm{V}^{3+}\right)$ за фоотокаталитичку и микробиолошку активност, као и њихово поређење са каталитичким активностима тестираних комерцијалних $\mathrm{TiO}_{2}$ (Дегуса П-25 и наночестица анатаса, чистоће 99,9\%, Алфра Аесар из Ланкестера). Титанијум-диоксид наночестице су синтетизоване $u$ допиране различитим концентрацијама металних допаната, током различитог трајања калцинације, као што су: $\mathrm{TiO}_{2}-\mathrm{H}$ П (анатас-НПс, време трајања калцинације од 5 и 7 h), $\mathrm{La}^{3+}(0.65,1,2,3,4,5$ и 6 тежинских \%, са трајањем калцинације од 7 h), $\mathrm{Fe}^{3+}(1,2,5,3,0$ и 5 тежинских \%, са трајањем калцинације од 7 i 24 h) $и V^{3+}$ (10 тежинских \%, са трајањем калцинације од 7 и 24 h). Сојеви „Pseudomonas aeruginosa DV 2739 и АTCC 9023" коришћени су као модел микроорганизама у микробиолошком делу експеримената који су изведени у микробиолошком кабинету. Заједнички фотокаталитички и микробиолошки процеси изведени су у циркуларном фоотореактору са емулгованим катализатором у присуству директног УВ зрачења симулираног натријумовом лампом „SONT UV400”. Студија је показала да узорак катализатора C28, Ла-допанта са концентрацијом од једног тежинског \%, показује најбоље фотокаталитичке особине од свих La-допаната, али најбољу фотокаталитичку активност од свих катализатора постигнут је код C111 узорка, Fe-допанта (5 тежинских \%, трајанје калцинације од 7 h). Наши резултати такође показују различити степен деградације када је коришћен V-допант $\mathrm{TiO}_{2}$, у концентрацији од 10 тежинских \%, узорци С93 и С96, синтетисани са различитим трајањем калцинације (7 и 24 h) и брзином загревања током 
калцинације (67,5 i 135 o C/h, редом), што се може објаснити аномалијом у њиховом понашању. Коначно, најбоља антимикробна активност добијена је коришћењем узорка S24, Fe-допанта, који је показао да концентрација од 0,25 mg/L може бити токсична за микроорганизме. У складу са нашим резултатима супериорних карактеристика Fе-допанта и теоријских знања за наночестице $\mathrm{TiO}_{2}$ допираних $\mathrm{Ag}$, Au и $\mathrm{Fe}$, дошло се до смерница за даља истраживања њихове фотокаталитичке $u$ антимикробне активности, као и за развој титанијум-диоксид наночестица и нанотуба за унапређење антибиотика и њихову употребу у лечењу рака.

Кључне речи: титанијум-диоксид, $\mathrm{TiO}_{2}$-наночестице, $\mathrm{TiO}_{2}$ допиран са $\mathrm{La}^{3+}, \mathrm{Fe}^{3+}$ u $\mathrm{V}^{3+}$, трајање калцинације, Сојеви Pseudomonas aeruginosa DV 2739 u ATCC 9023, фотокаталитичка активност, антимикробна активност.

Paper received on / Дата получения работы / Датум пријема чланка: 24.04.2018. Manuscript corrections submitted on / Дата получения исправленной версии работы / Датум достављања исправки рукописа: 04.07.2018.

Paper accepted for publishing on / Дата окончательного согласования работы / Датум коначног прихватања чланка за објављивање: 06.07.2018.

(C) 2018 The Authors. Published by Vojnotehnički glasnik / Military Technical Courier (www.vtg.mod.gov.rs, втг.мо.упр.срб). This article is an open access article distributed under the terms and conditions of the Creative Commons Attribution license (http://creativecommons.org/licenses/by/3.0/rs/).

() 2018 Авторы. Опубликовано в «Военно-технический вестник / Vojnotehnički glasnik / Military Technical Courier» (www.vtg.mod.gov.rs, втг.мо.упр.срб). Данная статья в открытом доступе и распространяется в соответствии с лицензией «Creative Commons» (http://creativecommons.org/licenses/by/3.0/rs/).

() 2018 Аутори. Објавио Војнотехнички гласник / Vojnotehnički glasnik / Military Technical Courier (www.vtg.mod.gov.rs, втг.мо.упр.срб). Ово је чланак отвореног приступа и дистрибуира се у складу са Creative Commons licencom (http://creativecommons.org/licenses/by/3.0/rs/). 